\title{
Contested sustainability standards in Indonesian agriculture
}

Citation for published version (APA):

Wijaya, A. (2017). Contested sustainability standards in Indonesian agriculture: on the process of claiming government authority. [Doctoral Thesis, Maastricht University]. Datawyse / Universitaire Pers Maastricht. https://doi.org/10.26481/dis.20170927aw

Document status and date:

Published: 01/01/2017

DOI:

10.26481/dis.20170927aw

Document Version:

Publisher's PDF, also known as Version of record

\section{Please check the document version of this publication:}

- A submitted manuscript is the version of the article upon submission and before peer-review. There can be important differences between the submitted version and the official published version of record.

People interested in the research are advised to contact the author for the final version of the publication, or visit the DOI to the publisher's website.

- The final author version and the galley proof are versions of the publication after peer review.

- The final published version features the final layout of the paper including the volume, issue and page numbers.

Link to publication

\footnotetext{
General rights rights.

- You may freely distribute the URL identifying the publication in the public portal. please follow below link for the End User Agreement:

www.umlib.nl/taverne-license

Take down policy

If you believe that this document breaches copyright please contact us at:

repository@maastrichtuniversity.nl

providing details and we will investigate your claim.
}

Copyright and moral rights for the publications made accessible in the public portal are retained by the authors and/or other copyright owners and it is a condition of accessing publications that users recognise and abide by the legal requirements associated with these

- Users may download and print one copy of any publication from the public portal for the purpose of private study or research.

- You may not further distribute the material or use it for any profit-making activity or commercial gain

If the publication is distributed under the terms of Article $25 \mathrm{fa}$ of the Dutch Copyright Act, indicated by the "Taverne" license above, 


\section{Contested sustainability standards in Indonesian agriculture}

On the process of claiming government authority
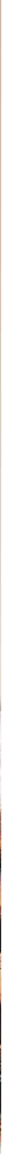
(C) copyright Atika Wijaya, Maastricht 2017

Cover design: Marsha Audra

Printing: Datawyse | Universitaire Pers Maastricht

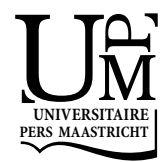

ISBN 9789461597427 


\title{
Contested sustainability standards in Indonesian agriculture
}

\section{On the process of claiming government authority}

\author{
DISSERTATION
}

to obtain the degree of Doctor at Maastricht University, on the authority of the Rector Magnificus, Prof. Dr. Rianne M. Letschert in accordance with the decision of the Board of Deans, to be defended in public on Wednesday 27 September 2017 at 14.00 hours

by

Atika Wijaya

born on 23 May 1984 in Surakarta, Indonesia 


\section{SUPERVISOR}

Prof. dr. Pieter Glasbergen

\section{CO-SUPERVISORS}

Prof. Purwo Santoso (Gadjah Mada University, Indonesia)

Prof. dr. Pieter Leroy (Radboud University)

\section{ASSESSMENT COMMITTEE}

Prof. dr. Shyama V. Ramani (chair)

Prof. dr. Arno F. A. Korsten

Prof. dr. Peter Oosterveer (Wageningen University)

Dr. Ingrid J. Visseren-Hamakers (George Mason University, USA)

Dr. Verena Bitzer 


\section{CONTENTS}

Chapter 1 Introduction 7

Chapter 2 Toward a new scenario in agricultural sustainability certification? The 25 response of the Indonesian government to private certification

Chapter 3 Governance challenges of cocoa partnership projects in Indonesia: Seeking synergy in multi-stakeholder arrangements for sustainable agriculture

Chapter 4 The Mediated Partnership Model for more sustainable coffee production in Indonesia

Chapter 5 Public agricultural extension workers as boundary workers: Identifying sustainability perspectives in agriculture using Qmethodology

Chapter 6 Conclusion and reflection

References

Appendixes

Summary

Ringkasan 163

Valorization 169

Acknowledgements 175

About the author 178 



\section{Chapter}

Introduction 


\subsection{Background}

Over the last twenty years, we have seen a proliferation of private sustainability standards and certification schemes for the production of agricultural commodities in Southern countries. These standards and schemes can be regarded as global value chain approaches, intended to create more sustainable agriculture in producing countries. Most of these approaches are developed by Northern-based businesses and nongovernmental organizations (NGOs) or by partnership arrangements between them (Bartley, 2010; Fuchs, Kalfagianni, \& Havinga, 2011; TSPN, 2011).

The process of regulating agricultural production through defining sustainability standards and rewarding compliance through the provision of sustainability certificates started in Europe and the United States around 1940. The discussion concentrated on organic farming as a potential response to the industrialization of agriculture and its negative environmental consequences (Kuepper, 2010; Heckmann, 2006). Growing interest in organic farming led to the development of many organic standards (i.e., for many different products) and facilitated the establishment of the International Federation of Organic Agriculture Movements (IFOAM) in 1972. IFOAM aims to develop internationally accepted standards and a quality assurance system for organic farming (Luttikohlt, 2007; Sawyer, Kerr, \& Hobbs, 2008).

Later, more sustainability standards and certification schemes became prominent in international trade. Fair Trade, formerly Max Havelaar, was initiated in 1988 to address poverty and social injustice (Reinecke, Manning, \& von Hagen, 2012). In 1989, the Rainforest Alliance (RA) was established, which mainly focuses on biodiversity conservation and sustainable forestry (Rainforest Alliance, 2016). In 1993, the Forest Stewardship Council (FSC) was founded, which devoted itself fully to sustainable forest management (Gulbrandsen, 2012; Visseren-Hamakers \& Glasbergen, 2007). This trend of developing new schemes continued into the $21^{\text {st }}$ century with the establishment of the Roundtable on Sustainable Palm Oil (RSPO) in 2004 (Potts et al., 2014).

In the 2000s, private companies started to develop their own company-based standards. Examples include UTZ Certified (now an independent organization, but initially set up by Ahold Coffee), Starbucks C.A.F.E. Practices (2004) and Nespresso's AAA (2003). These company standards aim to secure a high-quality coffee supply that meets a number of sustainability requirements. A recently developed standard is $4 \mathrm{C}$ (Common Code for the Coffee Community), initiated in 2006 by industries and governments, which serves as a baseline standard for other, more stringent standards. All these standards provide a label for their products as proof that the production process followed sustainability principles. These labels are communicated to buyers and consumers to distinguish different niche markets worldwide.

A very complex and often confusing system of sustainability standards has now materialized (Bitzer, 2012; Busch, 2014; Smith \& Fischlein, 2010). Furthermore, standards 
overlap and compete with each other for a share in the market. A good example of this situation is presented by the coffee sector, which can be seen as a pioneer in agricultural sustainability standards. There are many coffee certification schemes that are similar to some extent but also have different characteristics (Kolk, 2011; Arifin, 2010; Bitzer, Francken, \& Glasbergen, 2008; Hoebink et al., 2014; Potts et al., 2014). Similarities can be identified regarding their objectives, principles, processes, and even organizational structures (Dingwerth \& Pattberg, 2009: p.708). Differences are reflected in the different focal points that are addressed in each scheme. Organic, Bird Friendly Coffee, and RA, for example, emphasize the environmental aspects of coffee production (Giovannucci \& Ponte, 2005; Reinecke et al., 2012), whereas Fairtrade certification focuses on improving farmers' livelihoods through a better organization of farmer groups and the realization of guaranteed minimum prices (Reinecke et al., 2012).

These private agricultural sustainability standards, however, are also contested. Part of the criticism concerns their democratic legitimacy and inclusiveness, as Southern producers are often hardly involved in the development of the standards. Therefore, the standards mainly represent a Northern interpretation of sustainability, which does not necessarily coincide with a Southern or producer-driven interpretation of the concept (Fuchs et al., 2011; Schouten \& Glasbergen, 2011; von Geibler, 2013; Ponte \& Cheyns, 2013; Cheyns, 2014; Bitzer \& Glasbergen, 2015). It is also questioned whether the standards and certification schemes actually improve the livelihood of Southern smallholder producers. Impact studies investigating the effects of sustainability certification on farmers show mixed, and sometimes even conflicting, results (e.g., Ruben \& Fort, 2012; Chiputwa, Spielman, \& Qaim, 2015; Astuti et al., 2015; Hidayat, Glasbergen, \& Offermans, 2015; Van Rijsbergen et al., 2016). These findings reflect the fact that the Northern-based standards so far have only resulted in incremental changes and have not brought about a systemic sustainability change in the agricultural sector.

The value chain approach underlying the standards, which implies that sustainability changes can be realized through the market mechanism, has also been criticized by other parties in general and by Southern governments in particular. More recently, this has resulted in a new generation of sustainability initiatives from developing countries, which constitute a countertrend to the Northern standards (Schouten \& Bitzer, 2015). Examples are the Indonesian public schemes for sustainable palm oil (ISPO), coffee (ISCoffee) and cocoa (ISCocoa), or the Malaysian standard for sustainable palm oil (MSPO) (see also Hospes, 2014). Other examples are the Brazilian Soja Plus standard (for soy) and Certifica Minas Café (for coffee; Schouten \& Bitzer, 2015).

In this introduction to the dissertation, we argue that such a Southern response of claiming public authority over private actors in the agricultural sector has become inevitable and has been taking place in a tense atmosphere. Selecting Indonesia as the study site, we are particularly interested in identifying tensions and the ways in which these 
tensions are reflected in different institutional arrangements. We define institutional arrangements as a well-established cooperation for collective actions between one or more domains (i.e. public, private, and civil organizations) to achieve common objectives through establishing regulations. Beside the private sustainability standards and certification schemes mentioned above, public-private partnerships and development projects also form part of the institutional arrangements studied in this dissertation. We also wonder what the manifestations of tensions imply for the process toward more sustainable agricultural production, as well as for the roles, responses, and maneuvering room of governmental actors in this process of change.

\subsection{The inevitable involvement of Southern government}

The ever-increasing institutionalization of private sustainability standards, which made clear that consumer demands and consumer markets were changing, meant that Southern governments could no longer ignore these private standards and were forced to define their position in the discourse about sustainability claims on agriculture commodities produced in their territories. We can provide several reasons why a response from the Indonesian government was required.

First, and related to the aforementioned issue of regaining authority, governments may want to respond to private sustainability schemes in order to prevent the creation and preservation of power asymmetries. Traditionally, the regulation of trade is considered to be the responsibility of governments (Birner \& Resnick, 2010). In fact, the emergence of private sustainability standards can be considered a response to the observation that Southern governments were unable or unwilling to bring about sustainable change. However, taking over the governments' responsibility to regulate trade may disturb power balances and create "asymmetric" power balances and competitiveness between Northern private actors and Southern public actors (Bartley, 2010; Hatanaka, 2010). Moreover, asymmetric power can be seen in the formulation of private standards in which the Southern public actors and local stakeholders are not involved. The exclusion of Southern actors might result in their rejection to comply with the private standard, because their interests are unrepresented (Hatanaka, 2010).

Second, the private sustainability standards and certification schemes generally need to be aligned with national regulations in order to implement or support their requirements. Although the emergence of private standards is intended to fill the absence of the government in bringing about sustainable change, their implementation at the local level cannot bypass the role of government. To be effective, private standards need to integrate existing public policies such as land use planning and procurement policies into their activities (Gulbrandsen, 2012; Pattberg, 2006). Certification schemes for sustaina- 
ble forest management, for example, need to connect with land use policies to combat illegal logging successfully. Private regulations therefore often ask, or even urge, Southern governments to improve the enforcement of their public regulations.

Third, Southern governments have to protect their farmers from confusion in the presence of many different kinds of certification schemes. Earlier research shows that certification as a sustainability tool, which consumers are assumed to prefer because of the environmental and social conditions of production, tends to be interpreted by the smallholders in coffee, palm oil, and cocoa as a marketing tool to increase their income. This does not necessarily mean that farmers do not value environmental concerns or the social aspects of their practices, but their preferences regarding certifications are primarily economically driven (Ibnu et al., 2015; Hidayat et al., 2015; Nur Aini \& Soetanto, 2013). In addition to this matter, sustainability standards are often too complex and challenging for farmers to comply with. The application of organic standards also requires the farmers to adopt more difficult and time-consuming farming practices, which create a feeling of uneven work distribution and responsibilities between farmers and Northern actors (Hatanaka, 2010). Consequently, it is difficult for farmers to obtain a sustainability certificate on their own. Furthermore, without private certification, farmers may lose access to the international market. Together with the fact that certification often goes together with higher costs for the producers (Bush et al., 2013; Pichler, 2013; Astuti et al., 2015) and the fact that local governments generally want to contribute to improving economic prosperity in rural regions, governments are triggered to provide farmers with less costly alternatives to private certification. In sum, governments want to protect farmers from a lack of access to the market.

Fourth, and related to the previous aspect but at a higher abstraction level, Southern governments need to react to private sustainability standards in order to protect their export economy. Although participation in private sustainability schemes is voluntary, ignorance of or withdrawal from such private schemes may adversely affect a country's trade. Southern governments may interpret this external interference induced by private sustainability schemes as a tool to discriminate against their products on the global market or to erect market barriers for their products (Gulbrandsen, 2012; Karns \& Mingst, 2004). Most Southern economies, including Indonesia, largely depend on the export of agricultural commodities. In 2015, the total export value of agricultural commodities in Indonesia reached US\$28.05 billion; 95\% came from estate crop commodities such as palm oil, coffee and cocoa (Directorate General of Estate Crops, 2015). Palm oil is responsible for the largest share of exported estate crops with 2.8 million tons in 2015, while coffee and cocoa are in fifth (384,000 tons) and sixth (333,000 tons) place for export volume among other estate crops commodities (Directorate General of Estate Crops, 2015). 
Fifth, sustainability standards are often presented as a symbol of good governance, as they promote transparency, accountability, and efficiency. Governments that are faced with, or criticized for, mismanagement, corruption, and other unacceptable governance practices may want to use these standards to improve their image at the international level (Bartley, 2010; Martinez \& Poole, 2004; Vermeulen \& Kok, 2012; UNFSS, 2016; TSPN, 2011). Governments can do so in different ways, for example by accepting parts or all of the private rules, integrating these rules into their policies, and constructing public standards inspired by the private standards.

In this dissertation, we will further explore these arguments for the involvement of Southern governments in private sustainability standards among a variety of institutional arrangements. Through this approach, we will address different forms of engagement of the national and local Indonesian governments and the interplay between these forms of engagement.

\subsection{Potential roles of governments}

Most research on potential governmental roles in private sustainability standards and certifications addresses the roles of Northern governments. Table 1.1 below provides an overview of these different roles, stratified according to the stage of development of the certification schemes (initiation, implementation, and monitoring). Historically, the urge of Northern governments to involve themselves in private standards stems from the fact that many discussions on food safety and sustainable products have taken place on the consumer demand side in the North. The involvement of Northern governments encourages other countries to support the private schemes; as a result, this movement effectively accelerates the agenda setting and implementation of private standards (Guldbransen, 2012; Steering Committee, 2012). However, the roles listed below are also applicable to Southern governments under certain conditions.

Table 1.1 shows the potential roles typically played by Northern governments at different stages. However, Southern governments may to some degree also play these roles, as some scholars do not differentiate between Southern and Northern governments (see Gulbrandsen, 2012; TSPN, 2011; UNFSS, 2016). In the initiation phase (i.e., when the standards are designed), governments generally play a limited role. This role often takes the form of financial support given by Northern governments, such as the Netherlands and Switzerland providing financial funding to FSC for the development of tropical timber certification (PBL, 2010; Steering Committee, 2012; Vermeulen \& Kok, 2012). Moreover, Northern governments may also provide expertise and technical advice as well as administrative support to guide the process of formulating private standards and certification schemes. These roles could also be played by Southern 
governments in the initiation stage, which is important to capture the interest of smallholders during the formulation of private standards.

Table 1.1 Framework of potential governmental roles in private standards

\begin{tabular}{|c|c|}
\hline Stages of development & Government contribution \\
\hline Initiation & $\begin{array}{l}\text { - } \\
\text { - } \\
\text { - } \\
\text { - Admancialinistrative support }\end{array}$ \\
\hline Implementation & $\begin{array}{l}\text { Facilitating role } \\
\text { - } \quad \text { Forging relationships between stakeholders } \\
\text { - } \quad \text { Connecting standards to local circumstances } \\
\text { - } \quad \text { Training of farmers } \\
\text { Supporting role } \\
\text { - } \quad \text { Providing legal requirements and physical infrastructure } \\
\text { - Developing incentives to apply for certification } \\
\text { - Improving consumer awareness and market demand } \\
\text { Purchasing role } \\
\text { - Developing procurement policies }\end{array}$ \\
\hline Monitoring & $\begin{array}{l}\text { - } \quad \text { Providing data and information for assessment } \\
\text { - } \quad \text { Promoting principles of transparency and accountability } \\
\text { - } \quad \text { Enforcing laws and regulations }\end{array}$ \\
\hline
\end{tabular}

Based on: Gulbrandsen, 2012; Steering Committee, 2012; KPMG, 2012; ITC, 2011.

More diversity in roles can be found in the implementation phase of certification schemes. In this phase, governments can play one or more roles such as facilitating, supporting and purchasing. The facilitating role refers to the provision of technical and administrative advice in order to connect the private standards with local circumstances and to train farmers who need to organize their practices in a more sustainable way (ITC, 2011; PBL, 2010). The supporting role includes providing the necessary legal requirements and physical infrastructure to enable or improve the performance of private certifications (Gulbrandsen, 2012; KPMG, 2012; Vermeulen \& Kok, 2012). Southern governments potentially play facilitating and supporting roles, which relate to the implementation at the local level. In their purchasing role, governments maintain the private certifications with their procurement policies, which can influence consumer acceptance of these private certifications (Gulbrandsen, 2012; Steering Committee, 2012). The purchasing role is usually played by governments from consumer demand countries.

The monitoring roles refer to providing data and information that are needed for assessment (Gulbrandsen, 2012). Governments may address administrative or technical aspects of certification by promoting principles of transparency and accountability, or by initiating procedural harmonization of the many competing standards and certifications in the field of agricultural commodities. However, governments perform their monitor- 
ing role indirectly. Private standards and certification schemes rely for assessment and monitoring on third-party organizations, which have a task to audit compliance with standards. This process requires governments to enforce laws and regulations to support compliance with standards and promote sustainability principles (Gulbrandsen, 2012). Currently, the International Social and Environmental Accreditation and Labelling (ISEAL) Alliance assumes such an umbrella role in monitoring and assessment, which brings together the foremost standard-setting and certifying schemes to work on the procedural aspects of standard setting and implementation rather than the actual content of standards. Furthermore, the United Nations Forum on Sustainability Standards (UNFSS) focuses on converging national-level issues of producing countries, including livelihood aspects for producers and rural development impulses. The UNFSS also critically reviews the transformational potential of voluntary sustainability schemes (UNFSS, 2016).

\subsection{Understanding sustainable agriculture as a contested concept}

Private sustainability standards and certifications can be considered part of the neoliberal trend in which the market system is led by large international traders and processors, serving the demand side of products and -in doing so- demanding specific requirements from Southern producers on the supply side of production. In this dissertation, we are particularly interested in the opposite trend, the process of claiming authority, in which Southern public actors on the supply side of the commodity chain aim to regain authority over the actors on the demand side (see Figure 1.1 below).

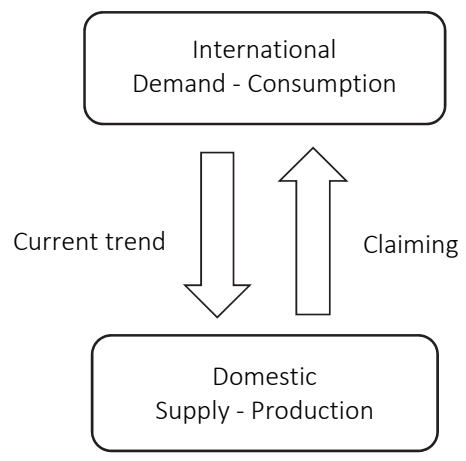

Figure 1.1 Contested authority in general

Claiming authority in global value chains offers challenges in aligning public and private responsibilities, global and local values, and knowledge and practice. Attempts at alignment inevitably create tensions and make sustainable agricultural production a contested concept (see Figure 1.2 below). In this dissertation, we identify three (interrelated) tensions. 


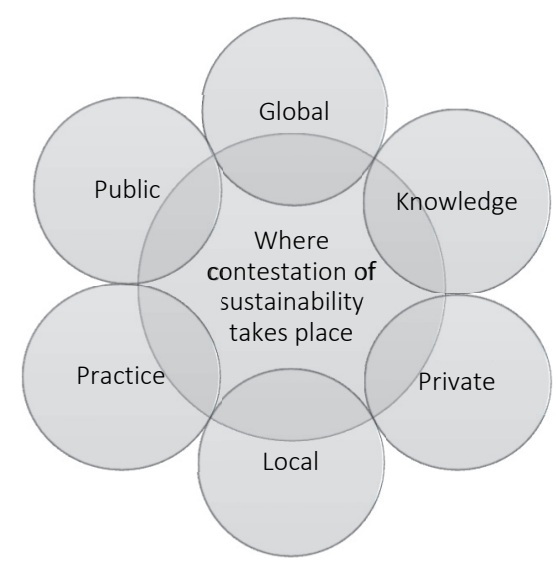

Figure 1.2 Dimensions of contestation

The first tension relates to increasingly blurred demarcations between public and private responsibilities for sustainability issues. The blurring of strict demarcations between private and public responsibilities may result in overlapping responsibilities and uncertainty as to who is supposed to take action on sustainability. This situation implies not only that private and public actors have to position themselves and their respective responsibilities in the field of sustainability, but also that some form of concordance is required. The emergence of private global sustainability standards bears testimony to the new role of businesses and NGOs in societal problem-solving (Bitzer \& Glasbergen, 2015), as they address issues that lie within the traditional realm of public actors (Waddock, 1989), including problems of agricultural production (Bitzer, 2012; Schouten, Leroy, \& Glasbergen, 2012). However, such private arrangements have also triggered a fierce debate about their legitimacy. Some authors welcomed these arrangements as drivers for change that address some of the most pressing sustainability issues (Cashore, 2002; Bartley, 2010; Schouten \& Glasbergen, 2011; Steering Committee, 2012). In that function, they may be seen as a supplement to governmental regulations or as an exponent of increased social complexity and differentiation, strengthening the vitality of democracy and its problem-solving capacities (Bäckstrand, 2006). Others regarded them as an infringement of public responsibilities by introducing barriers to trade for developing countries, impeding the regulatory authority of governments, and presenting a commodification of public interests that only serves the most powerful actors in the neoliberal society (Bernstein \& Hannah, 2008; Hatanaka, 2010; TSPN, 2011; Steering Committee, 2012). Moreover, almost all private certification schemes faced criticasters who challenged their "real" contribution to more sustainable change (e.g., Astuti et al., 2015; Giovannucci \& Ponte, 2005; Vellema et al., 2015; Chiputwa, Spielman, \& Qaim, 2015; Bitzer \& Glasbergen, 2015). Underlying this discussion is a fundamental uncertainty about the relationship between private and public actors, their responsibilities, legiti- 
macy, and effectiveness in public issues. The rise of private standards challenges traditional neoliberal reasoning that postulates a strict demarcation of public actors (the state and intergovernmental institutions), who are assumed to take responsibility for public issues, and private actors (businesses and civil society actors), who are only held responsible for private issues.

The second tension arises on the crossroad of global and local values on sustainability claims. Private sustainability standards and certification schemes are mainly developed by Northern actors. Farmers and governments from the South are often not involved at the initiation stage. This situation raises questions about the credibility of private arrangements and the extent to which private sustainability standards fit local values, knowledge, practices, and regulations in producing countries (Vellema \& van Wijk, 2014). Northern actors tend to particularly stress environmental sustainability and social justice (Vellema \& van Wijk, 2015; Bush et al., 2014; Hatanaka, 2010; Ponte, 2008), which are not necessarily prioritized in the same way by Southern actors. The tension between global and local values also becomes visible in the interpretation of private sustainability standards in domestic laws and regulations. Research indicates that private sustainability standards tend to disregard local knowledge and local values, and create ambivalence and hardship for farmers and local stakeholders in complying with these standards (UNFSS, 2016; Hatanaka, 2010). Although each standard claims to enhance sustainability, they fail to consider local differences or to provide farmers with the opportunity to voice their interests (Busch, 2014). Therefore, matching global and local values and interests seems essential to minimize frictions during and after the implementation of sustainability standards (Vellema \& van Wijk, 2015).

The third tension manifests itself when theoretical knowledge and notions need to be translated into concrete practices at the producer level. Sustainability is an inherently normative concept, which implies that different actors interpret it in different ways and give their own meaning to it (Henry \& Vollan, 2014; Offermans, 2012). As a consequence, farmers may not consider sustainability standards to be important for them economically or otherwise, even though the standards aim to improve farmers' livelihoods socially, environmentally, and economically. Besides, farmers often face difficulties in understanding the complex and rather abstract concept of sustainability (Abdulsamad, Stokes, \& Gereffi, 2015; Fahmid, 2013; Astuti et al., 2015). Many studies showed that the most common way to translate knowledge to practice is through intervention in the form of development projects, training, or private extension (Moriarty et al., 2014; Neilson, 2008). However, a question that so far remains unanswered is whether those interventions are effective in creating long-lasting sustainability changes in agriculture.

In this dissertation, we study how these tensions manifest themselves both at the producer level and through various institutional arrangements at the implementation stage of sustainability requirements. 


\subsection{Indonesia as a study site}

Our research focuses on Indonesia as one of the frontrunners in the development of public sustainability standards for agricultural commodities in response to private standards. Besides, there are more reasons to consider Indonesia to be a relevant study site for the research underlying this thesis.

First, Indonesia is an important producer of agricultural commodities. For exportoriented commodities such as palm oil, coffee, and cocoa, Indonesia is in the top four of largest producers globally. With regard to palm oil, Indonesia is in fact the largest producer in the world with a total production of 33,4 million tons in 2015, which represented $53 \%$ of the total global production of palm oil (European Palm Oil Alliance, 2016). Regarding cocoa, Indonesia ranks as the third-largest producer in the world with a total production of approximately 410,000 tons of cocoa beans (ICO, 2016). In the last five years, Indonesia has become the fourth-largest coffee producer with a total production of approximately 600,000 tons in 2016 (ICO, 2016).

Second, millions of Indonesian smallholders and their families depend on the production of agricultural commodities for maintaining their livelihoods. Agricultural production also provides job opportunities for more than 5 million people and contributes to economic growth in rural areas (Directorate General of Estate Crops, 2015). Around 96\% of the 1.2 million hectares of coffee plantations in Indonesia, for example, are managed by smallholders, representing the involvement of more than 1.9 million smallholder households. For cocoa, around $95 \%$ of the 1.7 million hectares of cocoa plantations are managed by more than 1.6 million smallholder households. In palm oil, we also see the involvement of large estates, but nonetheless around $41 \%$ of the 11 million hectares of oil palm plantations are managed by more than 2 million smallholder households (Directorate General of Estate Crops, 2015). On average, these smallholders own plantations of about 1 ha, have a rather low income, and often diversify their production to also include food crops and horticulture rather than depending on one commodity (Fahmid, 2013; Mawardi, 2009a).

Third, many development projects from the North over the past decades have chosen Indonesia as their project location, for example in the form of financing development projects to encourage the development of sustainability claims (VisserenHamakers, Arts, \& Glasbergen, 2007). Glasbergen and Miranda (2003, p.1) critically described this process as a "one-way transfer of money and morals." This quote explicitly touches upon the uneven relationship and power distribution between Northern actors as a donor and Southern governments as a recipient. Moreover, many NGO-based certification schemes for coffee and cocoa also target Indonesia as their focus area. They even go directly to the farmers at the local level and train them in principles and sustainability criteria. 


\subsection{Underlying trends in Indonesia}

To better understand the conflicts with and embedding of private sustainability standards in the Indonesian context, it is important to have a basic understanding of the political and economic situation in Indonesia.

It is important to be aware of the fact that the Indonesian government, when it comes to agricultural issues, prioritizes food crop commodities - especially rice - over plantation crops such as palm oil, coffee, and cocoa in its policies (Arifin, 2008). During the New Order regime of President Suharto, the government developed policies to increase the production of rice in order to realize self-sufficiency through massive inputs of technology. Suharto also used this policy to strengthen his political regime (Lindblad, 1996; Zanden \& Marks, 2012). In 1984, Indonesia finally succeeded in achieving rice selfsufficiency, a feat that was also recognized by the Food and Agriculture Organization (FAO). However, the success of rice self-sufficiency did not last long, because Indonesia issued a rice import policy in the 1990s following a significant decline in rice production due to a period of extreme drought. At the same time, the Indonesian economic policy shifted from the agricultural sector toward manufacturing and the industrial sector. The industrial sector was considered to be able to absorb more labor, including labor from rural areas.

Another trend in research that cannot be denied is the decentralization policy in Indonesia as from 1998-1999. Decentralization shifted responsibilities and authorities in the agricultural sector (and beyond) from the national ministerial levels (i.e., the Ministry of Agriculture) to local governments. These were given the authority for planning and managing policies, natural resources, and financial resources in their local territories. Although this policy had already been issued during the Suharto era, its implementation had been halfhearted, as monitoring was still centralized at the national level (Djohan, 2014). Under regional autonomy (i.e., as a result of decentralization), the choice of direction for developments in the agricultural sector largely depends on the local government's priorities. The current decentralized system is fragmented and complex. Sustainability standards and certifications that aim to change the production at the producer level need to find a way to handle this fragmentation and complexity, and to deal with different interpretations and support at the national or local levels respectively. At the national level, the private sustainability standards will likely be discussed in terms of advantages and disadvantages for the nation's economic development. At the local level, the private regulations will likely be discussed with a view to their impact on the livelihoods of the smallholders. Provincial and district governments will probably evaluate the regulations on their contribution to regional economic development. In practice, regulations and interpretations of standards from different governmental levels interact. For 
this reason, the governance of agricultural production through sustainability standards will be interpreted and studied as a multi-level governance challenge in this dissertation.

Trade liberalization also affected the Indonesian economy and forced the government to open its borders to attract more free trade (OECD, 2012; Arifin, 2008). This free trade also increased the number of private investments and development projects in Indonesia. Foreign actors such as multinational companies, international NGOs, and development organizations became increasingly active in the agriculture and plantation sector, particularly outside Java Island (Badrun, 2013). The Northern actors mostly targeted Sumatra, Sulawesi, and the eastern part of Indonesia because of their vast agricultural areas and their various commodities which have the potential to be developed. Unlike Java Island, which became the center of development during the New Order regime, the islands beyond Java are less developed and receive less attention from the national government. Therefore, the Northern actors used this situation as an opportunity to target such regions as part of agricultural development projects to empower smallholders. Notwithstanding neoliberal theories that predict economic benefits to all societal levels resulting from trade liberalization, some consequences for the Indonesian agricultural sector appeared, mainly for smallholder farmers. Whereas the farmers could previously count on direct government support in the form of fertilizers, they were now left alone after the government withdrew this support following requirements by the IMF (International Monetary Fund) and the World Bank. Another consequence is the influx of extremely cheap and imported products, which made it difficult for farmers to remain competitive (Bureau, Jean, \& Matthews, 2005). Furthermore, such products resulted in an import dependency, which troubles the vision of food security and severs farmers' income.

\subsection{Objectives and research questions}

So far, we have argued that Southern governments such as Indonesia, which are confronted with private sustainability claims, need to reconsider their authority in the market system. This process of "claiming authority" creates many tensions, as it is being realized in a decentralized and fragmented government system through various institutional arrangements.

Based on these considerations, we formulated the following objectives for this dissertation:

1. To contribute to knowledge of the sustainability contestation and the underlying power dynamics in different agricultural institutional arrangements. 
2. To contribute to knowledge of different ways of involvement of the government in these institutional arrangements and the implications for sustainability contestation.

3. To identify and explore opportunities and challenges faced by the government in its attempts to create a more sustainable agricultural production.

These objectives were operationalized in the following research questions:

1. How and why is the Indonesian government involved in sustainability contestations in the agricultural production of plantation crops?

2. What challenges do these involvements create for the government and how does the government respond to these challenges?

3. What do these involvements imply for viable forms of government interference in the process of creating a more sustainable agricultural production?

To answer these questions, this dissertation comprises four empirical studies, which represent different institutional arrangements in which the Indonesian government is involved through different sustainability contestations. In each empirically based chapter, we are looking at one or more dimensions of sustainability contestation and at the challenges that these contestations create in the process of realizing more sustainable agriculture.

The first empirical chapter addresses the contestation between public and private responsibilities in the national institutional arena. This chapter analyzes how the Indonesian government gradually reacted to the emergence of private sustainability certification schemes, why it decided to develop its own public standards and certifications, and what the emergence of public standards implies for the future of private standards and certifications.

The second type of institutional arrangements that we study is top-down development partnership projects (i.e., collaboration between international development organizations, an international NGO, and multinational companies), whose objectives to realize more sustainable agriculture are similar to the private certification schemes. This arena shows a contestation between global norms introduced by Northern actors and the local realities at the farmer level. The chapter analyzes the governance challenges of these arrangements and the process of seeking synergy between the actors involved.

The third type of institutional arrangement is not a top-down but a bottom-up perspective, initiated by local Indonesian actors. The objectives of these arrangements, however, are rather similar to the objectives of private schemes and partnership projects, and include the improvement of farmers' livelihoods and the promotion of more sustainable agricultural production. This chapter particularly shows contestations between abstract knowledge and farmers' practices at the local level, as well as beneficial and detrimental factors in a bottom-up partnering process. 
The fourth and final empirical chapter focuses on the Indonesian extension system, which aims to direct the agricultural sector to more sustainability, and in particular on the role of agricultural extension officers who directly interact with farmers. The main source of contestation stems from the encounter between the conceptual, rather abstract knowledge of sustainable agriculture on the one hand and the concrete practices at the grass-roots level among extension workers and farmers on the other hand.

\subsection{Methodology}

This dissertation employs a social constructivist methodology (Moses \& Knutsen, 2012). We argue that complex social phenomena, such as the sustainable transformation of agricultural production methods, can be interpreted differently by different actors. Social constructivism research on issues of certification typically perceives certifications and their potential impacts from the perspective of the subject of the study, which in our case are the actors involved in the production, distribution, or regulation of agricultural commodities. In this dissertation, we want to understand how these actors, in their interaction with each other, perceive, interpret, and shape a more sustainable agricultural production (see also Offermans \& Glasbergen, 2017). As a consequence, the concept of sustainability is not predetermined by the researcher but rather constructed through the perceptions of and the meaning given by the actors who have to deal with transformations toward sustainability.

In line with the social constructivist approach, we mainly apply qualitative research methods. Qualitative researchers have the choice to use and apply a rich diversity of methods. In this dissertation, we use and combine four main research methods.

1. Semi-structured face-to-face interviews

We conducted in total 108 interviews for four studies. Informants were chosen through purposive sampling based on their expertise and the relevance of their job or position to the research question. In various chapters, we used snowball sampling and asked initial informants to recommend new potential informants. The informants had various backgrounds, including government officials and staff, NGO employees, business actors, researchers, and farmers. All interviews were recorded with a voice recorder and transcribed. The transcripts were subsequently analyzed based on selected categories which were derived from different analytical frameworks in the individual chapters.

2. Document analysis

We collected and analyzed many documents, including documents from the internet such as laws and regulations, news articles from online and offline me- 
dia, annual reports, working plans, and other documents including statistical data.

3. Focus group discussions (FGD)

We conducted 7 FGDs; 1 FGD during the second empirical study on cocoa partnerships and 6 FGDs during the fourth empirical study on agricultural extension. The aim of FGDs is to gain information from a group of participants, to analyze the interaction between them (Barbour, 2007), and to gain insight into the existence and content of different views. We invited people from various organizations to sit together and discuss topics such as the implementation of cocoa sustainability projects, the function of extension workers, and the definition of sustainable agriculture.

4. Observation

We passively attended 7 meetings and conferences, such as conferences on palm oil and cocoa certifications, training of trainers (ToT), annual meetings of farmer cooperatives, a coffee stakeholders meeting, and a group meeting of extension workers at the ministry office. Our presence during these meetings and events allowed us to gain state-of-the-art knowledge on ongoing and newly developed initiatives at different governmental levels and for different crops. It also allowed us to observe the interactions between actors.

In the final study, we employed $Q$ Methodology to identify and compare different perspectives of 64 respondents on the concept of sustainable agriculture. QMethodology shares characteristics of both positivist and constructivist approaches. It is closely related to qualitative research in terms of the way in which statements are generated (i.e., in interaction with the respondents and through document analysis). Respondents subsequently rank the different statements and a statistical program makes two or more coherent and comparable sets of interpretations on sustainable agriculture based on these rankings.

\subsection{Relevance of the dissertation}

This dissertation is expected to contribute to the academically driven governance literature on sustainability standards and certification schemes for agricultural commodities. Particularly, this dissertation provides information on the confrontation between a global value chain approach and a domestic public approach, as well as its implications for the process of claiming authority by Southern states. The dissertation also relates the potential tensions that arise during, and resulting from, this confrontation, and how these are handled in practice in different institutional arrangements. Based on empirical research, the dissertation characterizes the potential roles of 
governmental actors in the South during the process of creating more sustainable agricultural production.

This dissertation is societally relevant, as it offers insights into governance practices for more sustainable agriculture in producing countries. These insights are relevant to a broad variety of actors, including government officials, business actors, researchers, NGO employees, and even farmer groups. For Southern multi-level governments, the dissertation shows the different ways of claiming authority and their implications for attempts to create more sustainable agriculture. This overview may help national and local governments to be better informed when determining their role in various institutional arrangements and when formulating viable policies in line with farmers' interests. For business actors, this dissertation provides information on the capabilities of partners and on strategies to develop such partnerships with public actors and farmers.

Although neither the existence nor the roles of NGOs are extensively discussed in this dissertation, these NGOs are necessary to assist farmers in practicing sustainable agriculture. This dissertation provides insight into the strategies to assist farmers through improving the coordination with public and private actors. For farmer groups in general, this dissertation may yield lessons derived from the experiences of other farmer groups that participated in the many training and development projects arranged by the government or private actors.

\subsection{Outline of the dissertation}

At the core of this dissertation is the process of claiming authority by the Indonesian governments over private actors, which process takes center stage in the confrontation between a global value chain (GVC) approach and a domestic public approach. The following chapters will answer the objectives and research questions that were discussed in this introductory chapter. The next four chapters are based on empirical studies, which describe the theoretical frameworks and methodology used in more detail. The final chapter will conclude and reflect on the main question and objectives of this dissertation. Figure 1.3 presents the structure of the dissertation and provides concise information on the consecutive chapters. 
Chapter 1. Contested sustainable agriculture:

Claiming public authority over private sustainability standards

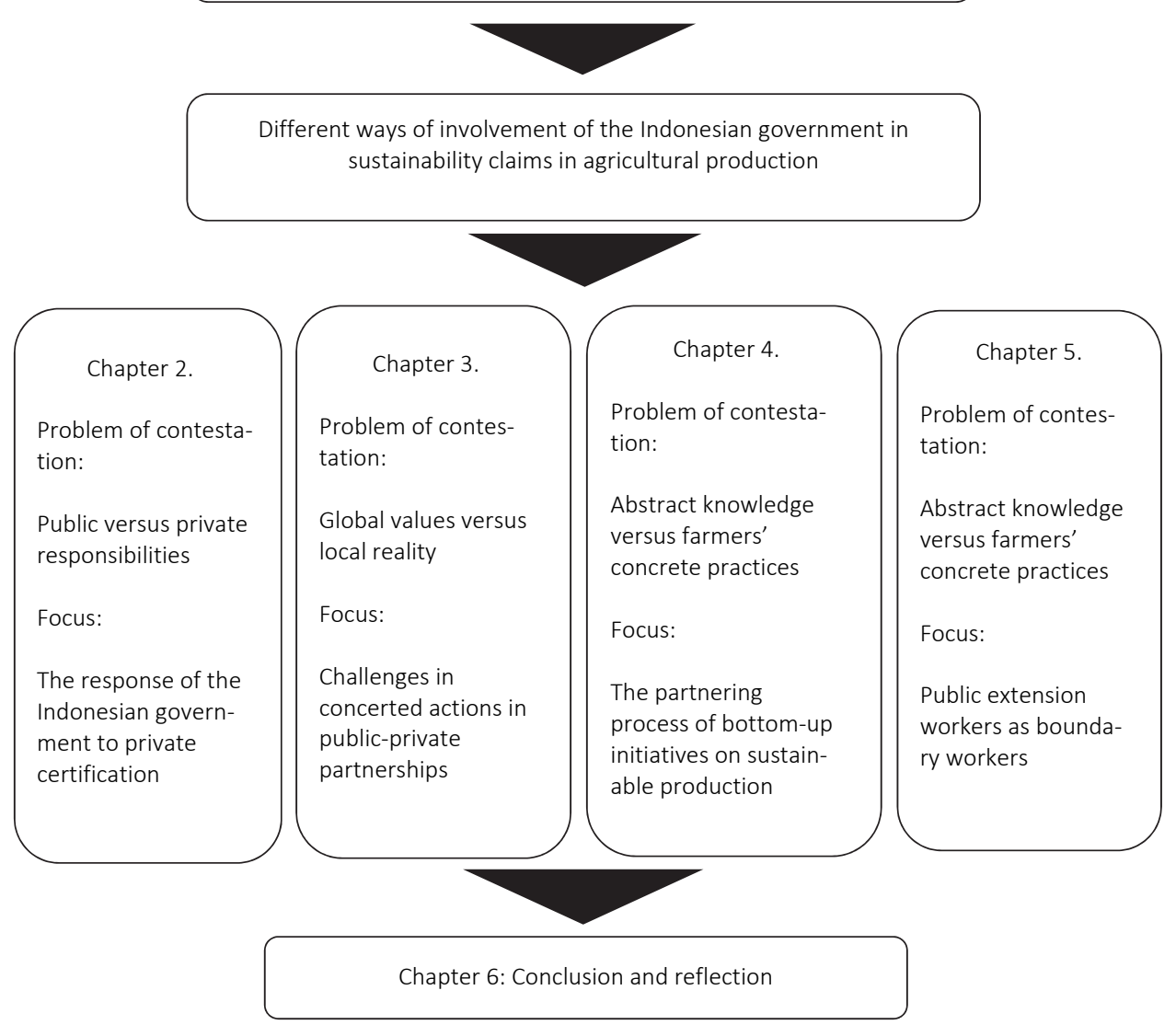

Figure 1.3 A visual outline of this dissertation 
Chapter

Toward a new scenario in agricultural sustainability certification? The response of the Indonesian national government to private certification 


\section{Abstract}

This chapter discusses a new development in the relationships between private sustainability standards and governments; one in which Southern governments reclaim the authority from mainly Northern-based businesses and NGOs. It examines how the Indonesian government, a forerunner in this field, responds to the private certification of palm oil. The results of this in-depth study are compared with similar trends in the coffee and cocoa sector in Indonesia. The chapter observes that a change takes place from a nonresponsive stance, a modest involvement in terms of sustaining the implementation of private certifications, to an active development of alternative public national standards and certifications. The chapter defines some factors that facilitate the development of Southern public standards as an addition or alternative to private regulations and reviews the implications for the future of private standards and certification.

Published as:

Wijaya, A. \& Glasbergen, P. (2016). Toward a new scenario in agricultural sustainability certification? The response of the Indonesian national government to private certification. Journal of Environment \& Development, 25(2), 219-246.

doi: $10.1177 / 1070496516640857$ 


\subsection{Introduction}

Since the mid-1990s, many, often competing, private sustainability standards have been developed for several agricultural commodities, such as palm oil, coffee, and cocoa (Bartley, 2010; Bitzer \& Glasbergen, 2015; Fuchs, Kalfagianni, \& Havinga, 2011; Marx, et al., 2012; Vellema \& Wijk, 2014). These standards and connected certification requirements aim to improve the social and environmental aspects of production at producer level while maintaining or improving the economic prospects of international trade. Many of them were initiated by collaborative arrangements of businesses and NGOs from mainly the North and particularly address the production of agricultural commodities in the South (Neilson, 2008). Governments, from both the North and the South, are hardly ever an official member of the new arrangements, although the schemes keep many connections with them, and some enlightened governments from the North sustain them.

Given their private and voluntary character, the new certifying schemes neatly fit into the liberal idea that sustainability can be realized through the market mechanism in a situation where governments are not willing or not able to address many of the sustainability aspects of the production of agricultural commodities. However, with their aim to create new management practices, private certifications not only interfere in the market, but also change the relationships between the actors involved in trade, among them governments (Henson \& Humphrey, 2010).

In recent studies, we can find a growing awareness of the interlinkages between private governance and public governance (i.e., Bartley, 2014; Glasbergen, 2011; Gulbrandsen, 2012; International Trade Centre, 2011; Mayer \& Gereffi, 2010, p. 15-16; Vermeulen \& Kok, 2012). These interlinkages have been studied from different angles. One of them is what they imply for the effectiveness of the private standards. This reflects in the literature that defines roles that governments could or should fulfill to improve the functioning of the private arrangements (Gulbrandsen, 2012; KPMG, 2012; Mayer \& Gereffi, 2010; Steering Committee of the State-of-Knowledge Assessment of Standards and Certification, 2012; Vermeulen \& Kok, 2012). Another, more reflective topic in current research regards the question (most prominently related to private governance in the forestry sector) whether private standards and certifications weaken or strengthen the role of government regulation (i.e., Bartley, 2014; Cashore, Auld, \& Newsom, 2004; Overdevest \& Zeitlin, 2014).

This chapter connects to these studies in a specific way, as it analyzes a new trend in the relationship between private and public regulation. This trend shows in public actors from the South taking the initiative, often inspired by earlier private regulations by Northern actors, to develop their own mandatory sustainability standards and certification schemes as an addition or alternative to the private regimes. This chapter under- 
stands this trend as a potentially new pathway to a more sustainable agriculture. The main objectives of our research are

- to answer the question how we can better understand this new role of governments of producing countries in terms of factors underlying it and

- to consider what this implies for the future of private standards and certifications.

Theoretically, the chapter connects to the emerging perspective that places private standards in the domestic political and economic context in which they aim to bring about changes (Bartley, 2014; Kalfagianni \& Pattberg, 2013b). From this perspective, private sustainability standards can be understood as external initiatives from the top of the value chain, which are channeled downwards as new conditions for production to producing, often developing, countries (see also van Dijk, Trienekens, \& European Association of Development Research Training Institute, 2012; Vellema, Ton, de Roo, \& van Wijk, 2013). In Southern countries, the private schemes are understood as external pressures for change. Many Southern countries struggle with these external pressures, which create uncertainties about the impacts of the private standards on their production sectors (see, e.g., Ponte \& Cheyns, 2013, on palm oil and fish; Ha, Bush, Mol, \& van Dijk, 2012, on shrimp; Van der Geest \& Unno, 2012, on aquaculture). However, these countries cannot easily refrain from taking action. Their economies are for a large part dependent on the export of agricultural products. The new conditions under which agricultural commodities are supposed to be traded under private sustainability regimes will also somehow affect their economic development policies. Moreover, through private regulatory activities in the areas of protection of human rights and natural resources, the private arrangements fulfill functions that are commonly thought to be the domain of the state (Bitzer, 2012; Glasbergen, 2013). As a consequence, producing countries need to make sense of the private regulations, decide on how to handle them, and how to react, given their national socio-economic situation and preferences.

Our research field is the national Indonesian government's response to private certifications, which is at the forefront of Southern reactions due to its position as the largest producer of several agricultural commodities. The heart of the empirical part of the chapter is an in-depth study of palm oil certification. We particularly study the response to the standards of the Roundtable on Sustainable Palm Oil (RSPO) over the period 20042014. The RSPO is a voluntary multi-stakeholder organization, initiated by businesses and NGOs from consumer countries in Europe. The RSPO excludes governments, both in membership and in the process of standard development. It has become an important certification scheme and reaches approximately $15 \%$ of certified palm oil in the global market (Schouten, Leroy, \& Glasbergen, 2012). The results of that study will be related to the governmental reactions to private certification of coffee and cocoa. 
The chapter is structured as follows: We first contextualize our research objectives by discussing conceptual approaches to private responsibilities and public policies. This is followed by a presentation of our research strategy. The heart of the empirical part of the chapter is an analysis of the shifting response of the national Indonesian government to the RSPO. Next, we compare this response to developments regarding two other export-oriented agricultural commodities (cocoa and coffee). In the conclusion, we discuss our findings.

\subsection{Conceptual approaches to public-private relationships}

Private arrangements may have both advantages and disadvantages for Southern countries. First, private sustainability standards and certification schemes may be favorable for governments because participating in them or sustaining them creates a good image at the international level (Martinez \& Poole, 2004; Trade Standards Practitioners Network, 2011). Second, and related, certification expresses a sense of good governance, which conveys a spirit of transparency, accountability, and efficiency. This is particularly important in developing countries that struggle with bad governance practices, such as corruption, and mismanagement of natural resources (Bartley, 2010; Vermeulen \& Kok, 2012). Third, governments may also indirectly receive the positive effects of certification. Certification may result in the transfer of technology, knowledge, and skills, induce more efficient management systems, and therefore upgrade the agricultural market conditions for the developing countries (Douma \& van Wijk, 2012; Martinez \& Poole, 2004).

Besides the opportunities, governments in the South may also face serious challenges related to private certifications. Agricultural commodities are crucial resources in developing countries and national governments often play an important management role (Birner \& Resnick, 2010). With the new governance systems producing countries are forced to share their authority in the agricultural management system. States may feel threatened because certification influences their national sovereignty and a state that is not ready for the global market may feel that private standards and certifications are a subterfuge of Northern countries (Trade Standards Practitioners Network, 2011). Southern governments may also consider certification as a tool to discriminate their products, because it is hard to fulfill the requirements and market access for some commodities may become more difficult (Gulbrandsen, 2012; Karns \& Mingst, 2010). Few scholars also recognize that the implementation of private standards can further increase what they call 'asymmetric power' between Northern and Southern countries due to an imbalance in power and competitiveness (Bartley, 2010; Hatanaka, 2010; Todaro \& Smith, 2003). Southern countries may feel that with the acceptance of the private schemes 
they are only meeting developed countries' needs, which are favorable for Northern multinationals, and, intended or not, disregard the needs of smallholders, their difficulty to change their way of farming, and their local values (Hatanaka, 2010).

Against this background of contrasting incentives of private standards for producing countries, we observe different, over time changing conceptualizations of the relationships between private regulation and public responses. We label them as leaving it to the market, recognition of dependencies, seeking congruence, and reclaiming public authority.

\section{Leaving it to the market}

This is probably one of the earliest conceptualizations and regards sustainability problems in value chains as problems of the market that need to be solved by the market actors themselves (see also Glasbergen \& Schouten, 2015). Producers are free to join the private schemes if they consider participation as favorable for their access to the market and trade relationships. But governments stay out of interference. An example is the primary reaction of the U.S. government to fair labor infringes in the apparel industry, which imported their products from producer countries in the South where production often took place under "sweatshop" conditions. The Clinton administration induced a conversation in which the main stakeholders could work on a private system, thereby bypassing the intergovernmental approach of the International Labor Organization, to address the problems. The arrangement that came out of it is the Fair Labor Association, to which many international brands are currently connected (Glasbergen, 2010).

\section{Recognition of dependencies}

This conceptualization is based on the recognition by Southern public authorities that sustainability standards may become important for the future development of agricultural sectors and may become favorable for parts of their trade in agricultural commodities. Private arrangements often need to be implemented in areas where laws are weak and not enforced, which implies that improved enforcement of national laws and a better communication among governmental agencies is a prerequisite for effective implementation of the private standards (see also Auld, Renckens, \& Cashore, 2015). Here, we observe the first manifestation of what Kalfagianni \& Pattberg (2013a) addressed as a "second order effect," the effects of private standards on public regulation. This has particularly been visible related to private standards that address sustainable logging and biodiversity conservation, issues that strongly depend on effective land-use planning and protection of community rights as well as collaboration between levels of government. 


\section{Seeking congruence between private and public regulation}

This conceptualization refers to a second-order effect that goes one-step further as the aim is to develop synergetic relationships between private and public standards on a more general, even intergovernmental, level. Bush et al. (2013), in their research in the field of aquaculture, suggest the institutionalization of Northern-led certification as part of a broader array of approaches including state and private regulation in the global South. Examples of this kind of linkages are the codification of private food safety standards and private organic production rules in national laws and international public regulations (Henson \& Humpfrey, 2010; Reinecke, Manning, \& von Hagen, 2012). Zadek (2010) refers to sustainable reporting as an example of an issue regarding which statutory instruments where developed on the back of voluntary standards. Kalfagianni and Pattberg (2013b) recognize that producers are developing their own interpretation of Good Agricultural Practices, which they then benchmark to an internationally recognized standard (GlobalGAP). Regarding the protection of forests, Bartley (2014) refers to intergovernmental agreements that oblige states in exporting countries to develop new legality licensing procedures, which is, amongst other countries, taken up in Indonesia (see also Sahide, Nurrochmat, \& Giessen, 2015).

\section{Reclaiming Southern public authority}

This new conceptualization refers to what Schouten and Bitzer (2015, p. 181) address as "the reposition of producer countries in global value chains." This conceptualization recognizes that both producers and governments in a Southern context tend to develop their own standards. Examples of the first category are Soja Plus as a rival standard of the Round Table on Responsible soy and the Sustainable Initiative of South Africa, an ethical program of the South African fruit industry. Examples of the second category are Brazil's Minas Café (Giovannucci, Von Hagen, \& Wozniak, 2013), China's attempts to promote its own domestically driven forest certification scheme (Bartley, 2014), Argentina's move from private forest certification to the state-guided governance of the Program for the Endorsement of Forest Certification (Giessen, Burns, Sahide, \& Wibowo, 2016), and the initiatives of Indonesia and Malaysia to develop their own standards on sustainable palm oil (Schouten \& Bitzer, 2015).

Our chapter particularly focuses on the last conceptualization, which has hardly been empirically studied yet. Thereby we assume that we can recognize a development path, in which experiences with the earlier conceptualizations influence the later ones. This study of the dynamics in the field of sustainability standards and certifications may also enrich our theoretical understanding of the prospects of attempts to make the trade in 
agricultural commodities more sustainable in changing relationships between Northern and Southern actors.

\subsection{Research strategy and methods}

To understand the response of the Indonesian national government to private certification schemes, we took a qualitative research approach. We specifically focused on responses to palm oil, coffee and cocoa private certification schemes because of the importance of these commodities in the Indonesian economy. The data collection process was undertaken in 2014. In-depth interviews and documents analysis are the main research methods employed in this study. To gain a comprehensive view of the Indonesian government response to private certification, we interviewed not only government officials but also informants outside the governmental bodies. The informants were chosen by purposive sample, due to their expertise in agriculture and private certification, and some of them by snowball sampling (see Table 2.1).

Table 2.1 The composition of informants

\begin{tabular}{|c|c|c|c|}
\hline No. & Type of informants & Institutions & $\begin{array}{l}\text { Number of } \\
\text { informants }\end{array}$ \\
\hline 1. & $\begin{array}{l}\text { Government official } \\
\text { and staff }\end{array}$ & $\begin{array}{l}\text { Ministry of Agriculture, Ministry of Trade, National Stand- } \\
\text { ardization Agency and ISPO commission }\end{array}$ & 11 \\
\hline 2. & Researcher & $\begin{array}{l}\text { Indonesian Coffee and Cocoa Research Institute (ICCRI), PT. } \\
\text { Research of Perkebunan Nusantara, and Hasanuddin Uni- } \\
\text { versity }\end{array}$ & 4 \\
\hline 3. & Practitioner & $\begin{array}{l}\text { Indonesian Cocoa Association, Indonesian Palm Oil Associa- } \\
\text { tion and Indonesian Coffee Exporters Association }\end{array}$ & 3 \\
\hline 4. & NGOs & BWI (2 times), FP2SB, Sawit Watch & 3 \\
\hline 5. & Expert & $\begin{array}{l}\text { IMO certification body, RILO (RSPO Indonesia Liaison Of- } \\
\text { fice), IDH and UTZ representative }\end{array}$ & 5 \\
\hline
\end{tabular}

Note. ISPO = Indonesian Sustainable Palm Oil; NGO = non-governmental organization; RSPO = Roundtable on Sustainable Palm Oil; BWI = Business Watch Indonesia; FP2SB = Forum Pengembangan Perkebunan Strategis Berkelanjutan; IMO = Institute for Marketekology; IDH = Initiatief Duurzame Handel/the Sustainable Trade Initiative; UTZ = UTZ certified organization.

The process of data validation was undertaken continuously during the interview period to find a pattern of the government's attitude, role, and policy in responding to the private certifications. Therefore, we also analyzed various documents, such as government regulations, news articles from online media (i.e., The Jakarta Post, which actively discussed Indonesian palm oil), and magazines such as 'Media Perkebunan,' which shows the government's position on estate crop issues in Indonesia. In addition, we also attended three important conferences, including the Indonesian Palm Oil Conference (IPOC), the Workshop on European Union Standards, and the National Seminar of Indo- 
nesian Cocoa Certification. During these events, we gained crucial information from stakeholders based on their speeches, presentation material and informal interviews concerning the topics discussed, including the private standards and certification schemes, and the government's responses.

In our empirical research, we are particularly interested in the dynamics of the process of role-taking and adaptation of the national government. To grasp the dynamic aspects of the Indonesian government's response to private certification we analytically distinguish between the general attitude towards private certification; the acceptance of a role, seen as the definition of what needs to be done regarding a specific agricultural commodity; and the policies, in the sense of the concrete activities that are employed related to the different private certifications over time.

\subsection{The shifting response of the Indonesian national government to the RSPO}

Agriculture has been a strategic sector of the Indonesian economy for many centuries. After the reformation period (1998) the agricultural market was liberalized (Organisation for Economic Co-operation and Development, 2012). The Ministry of Agriculture's (MoA, Central Bureau of Statistics, 2014) development policies were aimed at encouragement of the productivity of the sector and improvement of the basic quality of the production through private investments. Foreign actors, that is, multinational companies, became active in the agriculture and plantation sector, particularly outside Java Island (Badrun, 2013). As a response to the growing demand for palm oil worldwide, the land converted to plantations more than doubled in the last two decades. The land expansion was high, with an average of 315,000 hectares/year. The sector became a critical export earner and a major driver of rural development, providing more than three millions of people with a job in the Indonesian oil palm sector (Gillespie, 2012; McCarthy, 2010; McCarthy, Gillespie, \& Zen, 2012).

However, the past decade oversight of rules that were meant to regulate land conversion failed (Anggraini \& Grundmann, 2013), and the adverse consequences of palm oil expansion became more and more visible, such as land-use conflicts, loss of biodiversity, deforestation, peat destruction, and poor working conditions, particularly for the smallholders in palm oil (Brandi et al, 2015; Gillespie, 2012).

When the RSPO established in 2004, the process of land conversion to palm oil plantations with its devastating environmental effects was likely to increase, given the government's positive attitude towards expansion and the profitability of private investment in palm oil. However, drawing on our fieldwork in Indonesia we observe that the response of the Indonesian government to the RSPO shows some remarkable changes over time: From leaving it to the market (2004 to 2006), via an interim period in which 
the national government became involved in the RSPO activities and better known with sustainability standards and certification as a new policy instrument in the global market (2006 to 2009/2010), to the development of its own national standard and certification scheme (2011 to present).

\section{First response: Leave it to the market}

The initiation of the RSPO, with its objective to induce a more sustainable production of palm oil, did not change the Indonesian focus on productivity. The Indonesian Palm Oil Association or Gabungan Asosiasi Pengusaha Kelapa sawit Indonesia (GAPKI), the leading palm oil producer association in Indonesia, and also a main driver of the economic success of the sector, has been an early member of the RSPO. Founded in 1981, GAPKI is an initiative of palm oil entrepreneurs to face the challenges and opportunities in the development of the palm oil industry in Indonesia and in the global market. Over 630 company plantations are members, and they include state plantation companies, national and foreign private companies in Indonesian palm oil, and palm oil farmer groups (GAPKI, 2013). GAPKI takes a strong position in the Indonesian palm oil sector. Although its main interest to participate was to prevent reputational damage of the Indonesian palm oil industry, this was seen as a success from the viewpoint of the RSPO initiators (Schouten \& Glasbergen, 2011). Given its important position in the palm oil sector in Indonesia, GAPKI keeps a close relationship with the Indonesian government. The government considers GAPKI as a partner, particularly for the economic development of the palm oil sector because of (a) its ability to link the government with the producers, which reflects in the advisory role it plays regarding formulation of public policies for the palm oil sector, and (b) its ability to voice the interests and represent the Indonesian palm oil stakeholders in the international market. For instance, GAPKI often accompanies government officials in international forums discussing the palm oil industry (Bangun, 2010).

Indonesia, as the primary producer of palm oil in the world, could not fully neglect the new sustainable palm oil certification scheme. However, in the early years of the RSPO, the government regarded private standards and the certification as a business-tobusiness matter, so it was not regarded necessary for the government to be involved in it. The government left it to the producers to decide on participation in the voluntary RSPO scheme. Through its close relationship with GAPKI, which fulfilled a watchdog role, the government could consider the advantages and disadvantages of the RSPO activities. Moreover, through GAPKI's membership in the RSPO, the government could get valuable information about the development of the new sustainability requirements the palm oil industry started to be confronted with. 
Even though the national government took the stance of non-involvement with the RSPO, a relationship could not be avoided. The second principle of the RSPO states that producers or growers must comply with the laws and regulations applied in the country of the producers (RSPO, 2007). This stipulated an indirect role of the government as the legal provider of requirements that need to be fulfilled to make the implementation of the RSPO standards possible. Vermeulen and Kok (2012) referred to this as the "side line support" of the government because its position is outside the chain, but important in order to provide instruments (e.g., regulations) that influence the implementation of the certification. These regulations, for instance, the law of plant cultivation system, the forest law, and the environmental laws, had to fill the blank space that could not be filled by the private actors.

\section{Second response: Involvement in the RSPO activities}

The establishment of the RSPO Indonesia Liaison Office (RILO) in 2006, as a representative office of the RSPO, to improve the conditions for acceptance of the RSPO through communication and networking activities, has further influenced the implementation of this certification scheme in Indonesia. One of RILO's tasks was to establish the relationship with relevant agencies in the palm oil industry, particularly the Indonesian government. RILO recognized the potential role of the Indonesian government in supporting the implementation phase of the RSPO certification and initiated the Indonesian National Interpretation Working Group in 2006 and the Indonesian Smallholders Working Group (INA-SWG) in 2007. These "spaces of engagement" (Pesqueira \& Glasbergen, 2013), a concept that refers to the way actors are involved in the governance arrangement and recognize a relationship with the different dimenions of the sustainability problem, were necessary according to the stakeholders to adjust the principles and criteria (P\&C) of the RSPO to the national context in Indonesia.

The first working group, Indonesian National Interpretation Working Group, involves six different ministries, the National Land Agency, and the National Standardization Agency, next to other stakeholders such as GAPKI, World Wide Fund for Nature Indonesia, and banks (RSPO, 2008). The main task of this group was not only to translate the generic P\&C of the RSPO into Bahasa Indonesia but also to make an inventory of the national regulations and laws that had to be used as the basis for the implementation of the RSPO P\&C. The activities of this group were beneficial not only for the RSPO but also for the government itself, as the national interpretation was supposed to help the implementation of the national regulations as well. The outcome of this group is the National Interpretation of RSPO Principles \& Criteria for Sustainable Palm Oil Production, so the producers might be able to easily follow them. 
The second working group, INA-SWG, comprises the MoA and the ISPO Commission from the government, Sawit Watch (SW) and World Wide Fund for Nature Indonesia as NGOs, and GAPKI as representative of the producers. Smallholder representatives in this working group are the Oil Palm Growers Union (SPKS), the Indonesian Oil Palm Growers Association (APKASINDO), and the Nucleus Estate Smallholder-Oil Palm Growers Association (ASPEK-PIR). The main task of this group was the development of a national interpretation of RSPO P\&C for scheme and independent smallholders (RSPO, 2008). In the implementation, it is quite challenging to include smallholders in the RSPO certification scheme due to the barriers faced by independent smallholders in particular, for example, the limited access to the information and capital resources (Brandi et al., 2015).

Later on, RSPO and the MoA continued their work through a Memorandum of Understanding (MoU No. 39/KL.410/E.5.1/02/2009) about the implementation of sustainable palm oil in Indonesia. With this MoU, the government aimed to accelerate the development of sustainable oil palm plantations, particularly for smallholders. Through this MoU, INA-SWG developed Guidance for the RSPO P\&C implementation and conducted training on RSPO P\&C Training of Trainer for the regional facilitators (Fasilitator Daerah/Fasda). The Fasda's task was to train and assist farmers to apply for the RSPO P\&C. This training also involved the local government, particularly in Jambi and Riau. On this level, the MoA provided infrastructure and technical staff to sustain the implementation of the RSPO.

These new developments show that the attitude of the government towards the RSPO had changed from just leaving it to the market to accepting the RSPO and sustaining the standards and certification by providing legal regulations and technical expertise. This sustaining role is deemed necessary by all involved actors for the success of the RSPO standards' dissemination. Initially, the government is willing to be involved in the RSPO due to the invitation to give some thoughts regarding the RSPO P\&C; however, the government also considers advantages and opportunities for the development of the palm oil industry. This involvement is supposed to encourage producers to improve their production and gain a better market access. The government also participates in the expectation of gaining valuable knowledge on sustainability standards in this sector. Moreover, by supporting the RSPO, the government considers that Indonesia might be able to address the negative campaigns of international NGOs against the environmental effects of the palm oil industry.

\section{Third response: The establishment of an alternative national standard}

The considerable support of the RSPO did not last for long, only from 2006 until 2009/2010. According to our interviewees, the government got valuable information in 
the process of supporting the RSPO, for example, knowledge of what sustainability standards imply and the procedure of sustainability certification. However, the government considers that the voluntary character of the RSPO would not help to enforce the national laws and regulations. Moreover, the Indonesian government argues that the appropriate authority to regulate the sustainability of palm oil should be the government. It seems that, based also on the experiences with the RSPO, the government gradually got the confidence to formulate its own national standards for sustainable palm oil.

In March 2011, the MoA issued a ministerial decree on Indonesian Sustainable Palm Oil (ISPO). ISPO was developed by the MoA and the Indonesian Sustainable Palm Oil Commission (the ISPO Commission). The ISPO Commission is an official body, which was established by the Minister of Agriculture in 2003. This commission was initially established as a response of the government to the challenges and opportunities faced by the palm oil industry. The commission advices the minister of agriculture on every aspect related to the development of the palm oil industry, including preparing the establishment of the Indonesian sustainable standards for palm oil.

The development process of the ISPO was divided into four main stages: discussion, pilot test, public hearing, and finalization. First, several meetings and discussions were organized by the government. The meetings aimed to formulate the standards and principles that are appropriate in the Indonesian context. Second, field testing of 15 to 20 companies was organized by auditors from independent certification bodies. Third, a public consultation website based in Bahasa Indonesia and English languages was developed to obtain input from the stakeholders and community. Fourth, finalization of the draft of the regulation with the palm oil stakeholders and provincial or local offices as the implementers of ISPO (2013). Finally, the MoA issued the Regulation of the Minister of Agriculture Number 19/Permentan/OT.140/3/2011 concerning Guidelines of Indonesian Sustainable Palm Oil (ISPO) at the celebration of 100 years of Indonesian palm oil industry (Directorate General of Estate Crops, 2011).

GAPKI fully supported the development of ISPO. GAPKI withdrew its membership from the RSPO in September 2011. GAPKI gives its members the freedom to remain a member of the RSPO but requires its members to adhere to ISPO as a legal framework for the sustainable management of the palm oil sector. Feelings of unfair treatment by the RSPO mechanism play an important role in this decision. GAPKI is particularly disappointed about the implementation of RSPO because of the high cost of obtaining the certificate, what is regarded an unbalanced position in the decision making process between producers and other private actors, the uncertainties about a premium price for sustainable Crude Palm Oil (CPO), and the low uptake of sustainable certified CPO. Besides that, international NGOs keep campaigning against the Indonesian palm oil industry, although the producers feel that they already made many efforts to improve the 
situation. A few national NGOs believe that ISPO is a reaction of the Indonesian government to muffle the negative campaigns of international NGOs on oil palm plantations, as support of the RSPO is not able to reduce those campaigns.

\section{A comparison of ISPO and RSPO}

The presence of ISPO created a lot of speculation about the rivalry between ISPO and RSPO in palm oil sustainability. According to Hospes and Kentin (2012), the ISPO is similar to the RSPO principles, but ISPO is certainly not part of a race to the top in promoting sustainability. A comparison of the main characteristics of the certification schemes shows that in some aspects, the ISPO might be regarded a stronger certification system, particularly regarding the legal aspect. Both the RSPO and ISPO affirm that palm oil companies should adhere to the applicable laws and regulations. The RSPO states that requirement in the principle to comply with applicable national, local, and international laws and regulations, but as a voluntary scheme, no sanctions are imposed on noncompliance. The ISPO requires the compliance of national laws and regulations as a first principle. ISPO is legally binding for all palm oil plantations in Indonesia, except in an early phase independent smallholders, and it incorporates a sanction for noncompliance: The permit of the plantation will be withdrawn in case of violation of rules. Related, both the RSPO and the ISPO employ third-party certification bodies to conduct the assessment of the companies that apply for a certificate. However, in the case of the ISPO, the procedure is more complicated, as the first document verification is done by an independent auditor, but in next steps the ISPO commission and assessment team need to give their approval before the certificate is issued by the independent certification body. Regarding another pivotal principle of both schemes, the environmental aspects, there are minor differences. Common environmental topics cover environmental impact assessment, biodiversity conservation, water management, and so forth. But the detail with which they are described is slightly different. For instance, the RSPO discusses High Conservation Value (HCV) and refers to the international regulations as guidance for its implementation. HCV comprises a set of biological, ecological, social, and cultural values, which are considered of critical importance at the national, regional and global level. The ISPO mentions the term HCV, but there is no guidance or detailed information about it, which opens up opportunities for different interpretations in the implementation phase. In general, the RSPO also has more complete and detailed social issues in their P\&C, ranging from social impact assessment, community issues, to issues of gender and child labor. Moreover, the RSPO has detailed rules about community consent and land acquisition; free and prior informed consent is only taken up in the RSPO P\&C. The social and economic aspects in the ISPO are more normative statements, and they give 
less detailed information about the responsibility to the community (for a more detailed analysis, see also Hospes, 2014).

The commitment and confidence of the Indonesian government in the ISPO show in its active promotion of the scheme in the international arena. The prospective markets of CPO are China and India. To boost the performance of the ISPO, the MoA is coordinating with the Ministry of Trade and the Ministry of Finance to provide an incentive for the ISPO certificate holder. This incentive will take the form of a reduction of export tax on crude oil exports (Sudarsono, 2014). Meanwhile, some relationship with the RSPO is kept. In 2013, the MoA, the UNDP, and members of the private sector formed a publicprivate partnership called the Sustainable Palm Oil Initiative. The first step of this partnership is the RSPO-ISPO joint study of the similarities and differences of both standards (UNDP, 2013). The results of this study can lead to a collaborative audit for the same indicators to reduce the cost of auditing.

\subsection{Reflection on the palm oil case}

Our case study reveals a state-driven response to global claims for a more sustainable palm oil production in the South. When the RSPO became active in Indonesia, the government's attitude was that sustainability certification is something the market actors have to deal with, with no need of the government to be involved, while an allied representative of the sector fulfilled a watchdog function for the government. In what can be seen as an interim period, the government recognized that sustainability certification might become a prerequisite for global trade, started to cooperate with the RSPO, and played a role as a technical advisor and provider of the legal infrastructure to sustain the RSPO implementation. In the last phase, the government, for several reasons, changed its attitude, withdraw its involvement with the RSPO, and developed its own sustainability standards and certification scheme (see Table 2.2).

Table 2.2 The response of the Indonesian government to the RSPO

\begin{tabular}{|c|c|c|c|c|}
\hline & Response & Attitude & Role & Policy \\
\hline 1. & $\begin{array}{l}\text { Leaving it to } \\
\text { the market }\end{array}$ & Nonresponsive & $\begin{array}{l}\text { Watchdog role by } \\
\text { GAPKI }\end{array}$ & $\begin{array}{l}\text { Not involved with the } \\
\text { RSPO activities }\end{array}$ \\
\hline 2. & $\begin{array}{l}\text { Accept and } \\
\text { sustain it }\end{array}$ & $\begin{array}{l}\text { Aware of the sustainability } \\
\text { standard and accept the } \\
\text { RSPO's advantages }\end{array}$ & $\begin{array}{l}\text { Provide experts and } \\
\text { resources }\end{array}$ & $\begin{array}{l}\text { A collaborative program } \\
\text { between the RSPO and } \\
\text { the MoA }\end{array}$ \\
\hline 3. & $\begin{array}{l}\text { Looking for } \\
\text { an alternative }\end{array}$ & $\begin{array}{l}\text { Taking responsibility in } \\
\text { terms of national standard }\end{array}$ & $\begin{array}{l}\text { Set regulatory frame- } \\
\text { work for ISPO }\end{array}$ & $\begin{array}{l}\text { ISPO as a mandatory } \\
\text { national standard and } \\
\text { enforcement starts }\end{array}$ \\
\hline
\end{tabular}

Note. RSPO = Roundtable on Sustainable Palm Oil; GAPKI = Gabungan Asosiasi Pengusaha Kelapa sawit Indonesia; MoA = Ministry of Agriculture; ISPO = Indonesian Sustainable Palm Oil. 
Underlying these changes is, first, that the Indonesian government started to see the development of sustainable palm oil regulation as a national problem and, therefore, as a governmental responsibility. Even though the MoA supported the implementation of the RSPO earlier, it now regarded the alliance as less representative of the palm oil industry in Indonesia. Responding to the RSPO, a former government official commented,

The majority of RSPO members are manufacturers and banks and they are regulating the provisions in the upstream industry. I feel that this is wrong. Those who should regulate on the upstream side of the industry are the producer countries not private actors like the RSPO. So, in my opinion, it is a right decision that producer organizations in Indonesia (i.e., GAPKI) and Malaysia (i.e., MPOA) agreed to withdraw their involvement from the RSPO to set their own national standards.

National pride plays a role in this reasoning. Indonesia would like to assert its identity as a nation by establishing ISPO as a national standard (Media Perkebunan, 2013). Moreover, the government officials emphasize that Indonesia does not want to be led by Northern countries and assert that their identity through ISPO must be seen as part of their mandate to regulate. The national pride also concerns the Indonesian commitment to reduce greenhouse gases (GHG) emission resulting from palm oil plantations (Suharto, 2010; World Growth, 2011). At the Ninth Indonesian Palm Oil Conference (IPOC) organized by GAPKI, the President of Indonesia expressed this as follows: "Palm oil is one of the national prides. There is no doubt that the Indonesian Palm oil industries contribute to many positive impacts on society. Why do not we hear about these stories more than the bad ones?" (IPOC, November 28, 2013).

Second, the RSPO came to be seen as an illustration of an unbalanced power relationship between consumer countries and producer countries. GAPKI joined the RSPO, in accordance with the government's expectations, to improve access to the market and to dismiss allegations that the Indonesian palm oil is unsustainable. However, difficult requirements and expensive costs of the RSPO certification became disapproved by palm oil producers or growers (Pichler, 2013). Moreover, more intense negative campaigns by international NGOs were seen as detrimental to the industry; for example, the case of Unilever suspending its purchase of CPO from PT Smart was critically valued in Indonesia (Caroko, Komarudin, Obidzinski, \& Gunarso, 2011; Schouten \& Glasbergen, 2011). In addition, the procedures and the decision-making system in the RSPO were seen as unfavorable for the voice of producers, in which the system failed to include all the stakeholders in the palm oil industry (Pichler, 2013; Lestari, 2010). As we can see from the composition of the RSPO membership, the balance between producers and other private actors is 40:60, which implies that in the case of voting the producer's voice will probably lose. 
Third, the government came to see the private sustainability certification scheme more as a trade barrier. Palm oil is probably the most debatable vegetable oil and all the attention is directed to the producer countries of palm oil. These countries are held responsible for the environmental damage that goes together with the massive expansion of palm oil. Some palm oil entrepreneurs regret that the demand and consuming site of palm oil trade is hardly addressed. Describing the trade barrier in the palm oil industry, a palm oil practitioner commented,

Trading in plantation commodities is facing many non-tariff barriers, such as this private certification. The RSPO requirements are very complicated and the cost of a certificate is quite high, particularly for the smallholders. Responding to this, we have to think critically and ask ourselves whether we want our country, e.g., Indonesia, continuously controlled by European countries. So, it cannot be blamed if we assume that the RSPO is a scenario to suppress the Indonesian palm products which might make them less competitive than other vegetable oils.

Last, the Indonesian government aspires to use ISPO to expand new emerging markets of CPO. RSPO-certified palm oil is mostly asked by European buyers. However, the increasing demand for CPO is coming from Asian countries rather than European countries. According to the Data from the Central Bureau of Statistics (2014), India is the biggest importer of CPO with more than 5 million tons, and the second is China with more than 3 million tons, and their demand is increasing every year. These markets do not require sustainable certification; they only want a good basic quality and a reasonable price.

Against this background, it can be understood that the RSPO is no longer seen as in the interest of the Indonesian government and other Indonesian stakeholders in the palm oil industry. The Indonesian government started to play a more substantial role as a regulator of the sustainability standards of palm oil production. Although the stringency of the ISPO standards might be debated, the RSPO certainly brought about important changes in the government's policies. One of them is the recognition that, next to productivity, sustainability standards are important requirements for the future trade in palm oil. Another one is the recognition that a better enforcement of the many laws and regulations, in a more coordinated way among the many governmental agencies that are involved in palm oil, is necessary to keep the agricultural economy viable. A government official expressed the new thinking as follows:

The development of the trade sector is largely governed by consumers who desire a product. Usually, buyers in developed countries are aware about sustainability standards. Inevitably, we have to follow these standards if we want to expand our 
market. If we do not do so we can only sell in the domestic or regional markets and that means our trade is not going to thrive.

However, the ISPO is also criticized. Contrary to the RSPO, which was initiated by and involved international development and environmental NGOs, national NGOs knowledgeable in oil palm issues in Indonesia were not involved in the initiation of the ISPO. SW is one of the well-known Indonesian NGOs representing local people affected by the negative impacts of the large oil palm plantation system. SW joined as a member of the RSPO because it first established and even served as a member of the Executive Board (2005 to 2012). As a critical organization, SW believes that the RSPO could be a channel to voice the interests of marginalized people, who are harmed by the oil palm plantations, in international forums. However, SW is also disappointed about the complaints procedure in the RSPO. SW has reported that some of the certified companies do not implement the standards as they should do; land burning continues and there are still many conflicts with local people. However, the RSPO did not take actual action based on their report (Sawit Watch, 2010). Moreover, SW feels that it did not have much freedom to express its voice as a member of the executive board. As a consequence, SW choose to be an ordinary member and be involved in RSPO working groups to ensure that the RSPO P\&C fit with the national and local context. With those experiences in the RSPO, SW might be considered a valuable contributor to the initiation and implementation of ISPO, but SW nevertheless decided not to get involved in it. This is expressed as follows:

SW decided to not participate in ISPO, although the government had invited us. We saw that there was no equal position as the government and producers are very dominant in this scheme. The system of ISPO could not convince SW to join because government's vision is unclear and it starts to act out of its main function as regulator.

ISPO is a completely state-driven regulation sustained by the producers. Even though the government tried to invite NGOs in the implementation stage, they did not respond. Our interviews indicate that NGOs doubt the credibility of ISPO and the government. The NGOs suggest that the government should be a strong regulator and put more effort on law enforcement rather than applying its own certification scheme.

To conclude, the implementation of the ISPO has still a long way to go. Since its launch in 2011, the ISPO commission has developed various implementation plans. The original target was that by the end of 2014, all palm oil businesses would have complied with the ISPO guidelines. If not, they would get a sanction in the form of a decrease of plantation grade or class or their plantations' business permit would be revoked. However, this target seems unrealistic given the amount of palm oil companies in Indonesia is around 1,500, while the number of palm oil plantations that received an ISPO certifi- 
cate as per February 2014 amounted to 41 companies, and 81 other companies are in the process of assessment and verification to get their certificates (Subagyo, 2014).

\subsection{The Indonesian government's response to cocoa and coffee private certification}

The emergence of the ISPO is only one indicator that a new Southern state-driven scenario to realize a more sustainable agricultural production is in development. A further look at the responses to private certification of cocoa and coffee may reveal how deep the change is rooted. In spite of their different characteristics, these two export oriented agricultural commodities are also valuable for the Indonesian economy.

Indonesia ranks third among the world's cocoa producers, and more than 1 million farmers are involved in cocoa plantations. Several NGO-based private certification schemes are active in Indonesia (e.g., Fair Trade, UTZ, Rainforest Alliance[RA]) as well as some private companies investing in the cocoa industry that want to secure a goodquality and long-term supply of cocoa beans. Cocoa stakeholders realize the increasing demand for a sustainability standard for cocoa in the global market, which will also affect the cocoa industry in Indonesia.

In this case, the initiative for standard development was taken by a company (PT. Mars) and an NGO (Business Watch Indonesia). They formed a National Reference Group in 2010 -with representatives of certification schemes, research institutes, and governmental officials on an informal basis- which developed "a national indicator for sustainable cocoa production". The National Indicator is intended to help farmers and traders of cocoa to better understand and particularly prepare for the criteria of UTZ and RA certification. The indicator elaborates on seven aspects; farm management, post-harvest handling, product traceability, human resources, natural resources and biodiversity, management of certification, and social-environmental responsibility. In the indicator, the drafting team also listed government's regulations that fit the indicator. If producers meet the requirements of the national indicator, they are for $70 \%$ ready to apply for UTZ and RA certification.

National Reference Group officially delivered the national indicator to the Directorate General of Processing and Marketing of Agriculture Production (DG of PMAP), MoA, as the competent authority in standardization. Later, DG of PMAP invited more stakeholders to discuss the national indicator and the actions to respond to the many private certifications in Indonesia.

Before 2010, the Indonesian government took a nonresponsive attitude towards private cocoa certification. As long as it was supposed to have positive impacts on the productivity and would be profitable for the farmers, the government left it to the pri- 
vate actors and producers. However, the encouragement from private cocoa stakeholders to create some clarity in the emergence of many competing private schemes has influenced the government's reaction to (private) standards and certification. The Indonesian government considered the national indicator as a stepping stone to formulate its own cocoa national standard. DG of PMAP takes further action to make these indicators more reliable for the cocoa farmer in Indonesia by formulating Indonesian Sustainable Cocoa (ISCocoa). The formulation of ISCocoa involves not only several ministries next to the MoA but also PT. Mars, Business Watch Indonesia as national NGO, ICCRI as cocoa research center, BSN-KAN as a standardization authority in Indonesia, and representatives of UTZ and RA (Executive summary the draft of ISCocoa, 2013). Currently, ISCocoa is in the phase of finalization of the draft.

The target groups of ISCocoa are farmer groups. This is one of the main differences with the private certifications. The cocoa sector in Indonesia considers that the high costs of private certification make it difficult for smallholders to participate; the certificate holders are the traders or the companies. As a consequence, this is assumed to result in a weak bargaining position of the farmers in transactions about their harvest. With the forthcoming ISCocoa the farmer groups will be the certificate owners and they are assumed to achieve a better negotiation position.

Meanwhile, the establishment of ISPO and ISCocoa has inspired the government officials to also formulate the Indonesian Sustainable Coffee (ISCoffee) as a state-driven scheme. Indonesia is the third largest coffee exporter in the world and the largest exporter of Robusta coffee, however, the majority (75\%) of certified coffee is Arabica and only $25 \%$ of Robusta coffee is certified (Wahyudi \& Jati, 2012). The DG of Estate Crops, starting in 2012, invited some researchers from the ICCRI, with support of the Indonesian Coffee Exporter Associations, i.e., Asosiasi Eksportir Kopi Indonesia (AEKI) and Gabungan Eksportir Kopi Indonesia (GAEKI), to discuss the possibility of formulating sustainability standards for coffee.

The development stage started with several workshops with stakeholders, and standards have been tested twice in different regions (Directorate General of Estate Crops, 2013). The last draft of ISCoffee includes 5 principles, 23 criteria, and 87 indicators covering the legality of farmer's land; application of technical guidelines for cultivation, harvest and postharvest; environmental management and monitoring; responsibility for workers, and social and community responsibility. These P\&C are similar to the ISCocoa. ISCoffee is also a reaction to the many private coffee certifications in Indonesia, such as Fairtrade, UTZ, RA, 4C, and so forth. The national standard is expected to deliver what private certifications could not give, such as low cost of certification and the farmer groups as the certificate holders. ISCoffee, due to the fact that the state takes responsibility, also intends to protect the continuation of coffee supply and reap the benefits of a price premium. 
There are at least three pivotal reasons, none that different from the reasons behind ISPO, for the establishment of ISCocoa and ISCoffee. First, the government, sustained by the producer organizations, observes some disadvantages of private certification for farmers. Private certification may become burdensome for the farmers because of the complicated P\&C that they should apply. Moreover, many farmers do not really understand the benefits of sustainability standards for their livelihood. In addition, many coffee and cocoa farmers cannot afford the high cost of certification. Only big traders or companies can be acknowledgeable as certificate holders because they can pay these costs. The forthcoming ISCocoa and ISCoffee are designed for farmer groups so they can hold the certificate themselves, and have a better bargaining position in their transactions. As commented by a government officer,

In the field, private certifications seem to create unfair practices. There is no guarantee of the price premium like they said .... Private certification is only burdensome for farmers and the market share of certified products is very small. For instance, in the coffee sector the market share is not more than $4 \%$, while $90 \%$ is conventional market, and $6 \%$ is a specialty market.

Second, through ISCoffee and ISCocoa, Indonesia would like to strengthen its position as an important producer of coffee and cocoa. Government officials regard it inappropriate that foreign parties (e.g., NGOs, manufacturers, and retailers) regulate domestic agriculture management in Indonesia. This attitude is also supported by the majority of coffee and cocoa stakeholders. Furthermore, they feel that private certification creates a trade barrier that will inhibit Indonesian export, as the following comment by an expert in the field shows: "So far, more and more private certifications are present in the market and they make it very complicated. Some of them are illogical . . . It seems that they just want to make our trade affairs getting harder."

Last, the government designed ISCocoa and ISCoffee as a response to the new emerging market for coffee and cocoa. ICO (2014) data show that while the conventional market demand (European and United States) is steady and tending to be in decline, there is a promising market in Asian countries, Eastern Europe, North Africa, and even domestic consumption has potential. The government prefers to focus on the new market that does not require strict sustainability certification rather than being involved in private certification for the conventional market.

\subsection{Conclusion}

This chapter studied a new development in the relationships between private sustainability standards and the government. It particularly addressed what might become a new 
scenario in sustainability certification; one in which Southern governments reclaim authority from (mainly) Northern actors. From our studies in Indonesia we can derive some propositions about the dynamics of private-public interactions over time and the underlying factors of this dynamism.

First, we observe a process of learning. Because of the private schemes, the Southern government became aware of the relevance of sustainability standards for its trade and certification as a tool to handle them. With the new knowledge the government considered that it could better handle this itself instead of being dependent on foreign powers.

Second, also induced by the private schemes, the government started to reconsider the enforcement of its own regulations on environmental and social issues in the field of the production of agricultural commodities. Improvements of the national rules and the communication between government agencies involved in the production process contributed to the state capacity to handle sustainability aspects of the production processes.

Third, feelings of disadvantage and exclusion play an important role in the decision to develop national standards. The private standards are seen as regulations owned by multinationals and international NGOs, and not as something the national government may own as well. This feeling is strengthened by the emergence of ever more private standards, particularly related to coffee and cocoa. The increasing complexity of the "system" of private standards, with only small differences among the standards, creates doubts about the logic of the private regulatory system as a whole.

Fourth, we observe that, different from the private standards from the North, which are developed in a close cooperation between businesses and NGOs, the Southern standards are developed in close cooperation, with even corporatist governance characteristics, between producer organizations and the government. As a consequence, the economic prospects of the production of the agricultural commodities tend to get more emphasis than the social and environment consequences of production. This is framed as paying more attention and respect to the specific conditions of production and preferences in the local or national context.

Fifth, as an external factor, changing market opportunities plays a role. The Southern government observes a trend in which trade of agricultural commodities with other parts of the world than Europe and the United States becomes more important. These parts, for example China and India, are less interested in confirmation to the private sustainability standards as a prerequisite for a trade relationship.

Although the first Indonesian sustainability standards may not be that stringent, the fact that they are public regulations makes a more sustainable production less dependent on the rather unpredictable market dynamics, of which the private certifications are part. However, the new sustainability standards still need to be translated in changes on the ground and there are still many implementation problems to solve. In the palm oil 
case, for example, the RSPO aims to address the environmental degradation caused by the massive expansion of plantations. However, deforestation and all kinds of social problems related to oil palm production continued during the implementation phase of the RSPO. The question remains whether the ISPO will be better able to address this problem. The weak law enforcement is generally framed as the main cause of the environmental degradation. The ISPO and other forthcoming sustainable standards for cocoa and coffee based on public law might be an improvement, but they are also dependent on the coordination capacity of the national government and the provincial and local governments, and their communication with millions of farmers.

It is still uncertain how the new scenario will further develop, particularly whether the public national sustainability certifications will push the private certifications from the market. The most probable short-term scenario will be that of a very differentiated and fragmented market of private and public sustainability certifications, each of them serving parts of the global market. Stringent sustainability standards will then be applied for consumers in the North, while weaker standards will serve the South. However, if Indonesia and other Southern governments are really able to implement reliable sustainability systems it is certainly not impossible that in the long run they will replace the many -also competing among themselves- private schemes. Therefore, it is of importance to further study the implementation of the Indonesian standards and to make cross-national comparisons among other main producers of the same commodities. 



\section{Chapter}

Governance challenges of cocoa partnership projects in Indonesia: Seeking synergy in multistakeholder arrangements for sustainable agriculture 


\section{Abstract}

This chapter investigates multi-stakeholder arrangements initiated by businesses and NGOs from the North that aim to enhance a more sustainable agricultural production at specific localities in Southern countries. We aim to better understand the search for concerted action in multi-actor arrangements. Therefore, this chapter presents a diagnostic framework with three strategic challenges the partnership projects are facing: linking global economic objectives to local needs, values and interests; bridging public and private interests and responsibilities; and seeking trade-offs between social, environmental and economic values. Starting from the partnerships' Theory of Change, this diagnostic framework is applied to comparative case-studies of partnership projects in the cocoa sector in Indonesia, which are part of a Northern-based public-private partnership to improve farmers' prospective. It is concluded that the economic reality faced by the farmers differs from that of the Northern actors; collaboration with governments is difficult because of different organizational cultures; and the partnership projects underestimate the strength of vested social relations the smallholders are part of. Overall, the initiators of the partnerships seem to work with a too restricted economic interpretation of the local reality.

Published as:

Wijaya, A., Glasbergen, P., Leroy, P., \& Darmastuti, A. (2016). Governance challenges of cocoa partnership projects: seeking synergy in multi-stakeholder arrangements for sustainable agriculture. Environment, Development and Sustainability, pp.1-25. doi:

10.10007/s10668-016-9874-8 


\subsection{Introduction}

Initiatives to improve the sustainable production of agricultural commodities in developing countries are mainly taken by Northern-based businesses, non-governmental organizations (NGOs) and many forms of partnership between them. One of the ambitions is to positively influence the livelihood of smallholder farmers as the main producers of these commodities. Through various forms of voluntary private governance, occasionally with involvement of Northern governments, these partnerships have become important initiators of sustainable change in the production of coffee (Auld, 2010; Kolk, 2012; Manning et al., 2012), palm oil (Brandi et al., 2013; Hospes, 2014; Oosterveer, 2014; Schouten \& Glasbergen, 2011; Wijaya \& Glasbergen, 2016), tea (Glasbergen, 2013; IDH, 2013), cocoa (Bitzer et al., 2012; KPMG, 2013; Vaast \& Somarriba, 2014), aquaculture (Bush et al., 2013; Douma \& van Wijk, 2012; Hatanaka, 2010; Van der Geest \& Unno, 2012) and cotton (i.e., Bitzer \& Glasbergen 2010).

According to Glasbergen, such partnerships provide a managerial response to the general ethical ideal of societal progress. As self-organizing alliances, they are set up to solve sustainability problems on the basis of a shared commitment of the actors involved (Glasbergen, 2011). In essence, they aim to realize concerted action of actors that often have different and even conflicting values and orientations (Austin \& Seitanidi, 2012; Perez Aleman \& Sandilands, 2008). Stakeholders who are used to, or inclined to, act independently must now be stimulated to take part in concerted actions (Ansell \& Gash, 2008). This asks for some level of alignment or synergy.

Processes of alignment and synergy in multi-stakeholder arrangements have particularly been studied at the level of global institution-building in the field of private standard-setting and certifying partnerships (Bartley, 2011, 2014; Gulbrandsen, 2012; Steering Committee, 2012). However, less attention has been paid to private multi-stakeholder initiatives from businesses and NGOs from the North that aim to induce a more sustainable agricultural production in interaction with local public actors in Southern developing countries.

Some of these local initiatives have been initiated as local experiments to test the feasibility and limitations of private standards and certification schemes. Examples include the development and application of the Fair Trade, UTZ and 4C standards (Manning \& Von Hagen, 2010; Manning et al., 2012). Other local initiatives have been developed as a governance form independent from the certification schemes. This category of multi-stakeholder arrangements aims to bring together a broad array of public and private stakeholders in temporary organizational arrangements to work directly with farmers at the sites where economic, social and environmental reform is intended to take place. Rather than standard setting or certification, networking is the key lever towards social change here. Notwithstanding the temporary character of these projects, 
their intention is to induce long-lasting changes among a selection of smallholders that can be scaled up to an entire region. Since these are voluntary private initiatives, local actors might regard them as external incentives for sustainable changes.

This chapter takes a governance perspective to improve our understanding of the search for synergy in such partnerships, particularly in the cocoa sector in Indonesia. The governance perspective directs our attention to the process of oriented social change, aiming at the mobilization of problem-solving capacities in multi-actor arrangements. From this governance perspective, we also assume that the practical meaning of the partnership projects has to emerge from an interactive process of dialogue, reflection and learning, while recognizing the (problematic) power dimension in their interactions (Meadowcroft, 2007; Pajaro et al., 2010; Palmujoki, 2006).

In our study, concerted action refers to the ability to induce more sustainable farming practices and eventually sustainable system changes in the Indonesian cocoa sector (Glasbergen \& Schouten, 2015). Based on literature on partnerships we postulate three governance challenges inherent to these arrangements. Each of these challenges depict a strategic dilemma faced by partnership projects that demand the actors involved to align their interpretations of sustainable cocoa farming. This chapter uses these governance challenges as a "diagnostic framework" to investigate how the challenges are handled in practice and how this generates a common view on the development of new farming practices. Our ultimate objective is to identify potential encouraging and deterring factors regarding the development ambitions of the partnership projects. We derive these ambitions from a reconstruction of the partnership projects' Theories of Change (ToC). The concept of Theory of Change is particularly used in international development programs. It refers to assumptions, underpinning practices and pathways towards change, and it generally articulates why a given intervention may lead to a desired result (Mayne \& Johnson, 2015; Stein \& Valters, 2012). In our case, the ToC postulates a specific sustainable development outcome as the result of a specific Northern intervention in the farming practices in the South.

This chapter is organized as follows: First, we sketch the problem of cocoa farming in Indonesia. Second, we introduce the case studies followed by the conceptualization of the governance challenges. Next, we explain our research field and methods. The subsequent sections, then, present our research findings. The chapter's conclusions reflect on these findings, on the ToC, and on the partnership projects as a form of governance to induce long-lasting sustainable change. 


\subsection{On the problems of cocoa production}

Cocoa production is generally regarded as problematic from different sustainable development perspectives (KPMG, 2013; Moriarty et al., 2014; Suryatin \& Beatrice, 2013). Economically, the problems are centered around the low quality of the cocoa beans, which is generally caused by improper management at the farm level, limited knowledge on good agricultural practices, and over 25-years-old plants (Fahmid, 2013; Moriarty et al., 2014; Suryatin \& Beatrice, 2013). Consequently, cocoa plants are prone to pests and diseases and less productive (KPMG, 2013; Shapiro \& Rosenquist, 2004; Susanto, 1994).

Cocoa is one of the main export-oriented commodities of Indonesia. In addition to its value for export and trade, cocoa provides employment opportunities in rural communities and encourages regional economic growth (Antara \& Effendy, 2009; Fahmid, 2013). Indonesia is the third largest cocoa producer in the world with a total production of approximately 410 thousand tons of cocoa beans in 2014. Indonesia is however still far behind Côte d'Ivoire and Ghana as the top two cocoa producers with a production of 1449 and 835 thousand tons in 2014 respectively (ICCO, 2015).

In Indonesia, both the land area and the production of dry cocoa beans decreased over the last 5 years, particularly in South and West Sulawesi. The most significant decline occurred in 2011 when land area devoted to cocoa production in South Sulawesi shrunk by 8.7 \% from 273.91 ha in 2010 to 244.47 ha in 2011 (Ministry of Agriculture, 2014). At the time, the most severe decline in cocoa prices led to a shift from cocoa to other crops. Prices dropped by $30 \%$ due to an abundant production in Africa that was not paralleled by a similar increase in demand due to the economic crisis in Europe (Bappebti, 2012). Because of these low prices farmers lost their interest in cocoa farming and switched to other crops or abandoned their land (Fahmid, 2013; Li, 2002; Neilson, 2007).

Recent international forums have emphasized the need to intensify cocoa cultivation (Vaast \& Somarriba, 2014). However, it is unlikely that cocoa farmers are able to change their production practices on their own. They are often weakly organized and almost all of them are low income and small-scale farmers with less than 2 ha of land (Fahmid, 2013; Saleh, 2012). In general, they lack capital for investing in technical innovation, they are exposed to price volatility and do not have much insight into price setting mechanisms (Moriarty et al., 2014; Vaast \& Somarriba, 2014; Yanuardy, 2014). They also have limited knowledge about quality assurance systems and sustainability standards as demanded by the global market (Abdulsamad et al., 2015; Saleh, 2012). Cocoa farmers generally obtain information about cocoa farming from successful farmers in their neighborhood (Antara \& Effendy, 2009). The challenge is therefore to increase the Indonesian cocoa production to meet a growing global demand in such a way that it also improves the livelihood of the farmers (Vaast \& Somarriba, 2014). 


\subsection{The sustainable cocoa production program (SCPP): a case study}

One of the biggest Northern-based programs addressing problems in the Indonesian cocoa production is the Sustainable Cocoa Production Program (SCPP), initiated and funded by public and private actors. This partnership has been established in 19 districts in 6 provinces in Sulawesi and Sumatra since 2012. Public actors that are involved include the Swiss State Secretariat for Economic Affairs (SECO) and many Indonesian government agencies, while the private actors are the (government-funded) Dutch Sustainable Trade Initiative (IDH), and the businesses Armajaro, ADM Cocoa, Ecom, Mars and Nestlé. All these actors collaborate to provide farmers with training and education in agricultural practices and nutrition, and issues related to environment community, finance and businesses (Swisscontact, 2013).

The projects under scrutiny here are part of this SCPP partnership, implemented by Swisscontact; an international development NGO founded by the Swiss private sector. With over 40 years of experience in Indonesia, Swisscontact mainly works on the topics of tourism and cocoa. Its objective is to contribute to sustainable economic development at the regional level. In this chapter, we focus on three regions in Sulawesi, which is the most important cocoa producing area in Indonesia.

\subsection{Governance challenges: A diagnostic framework}

Following Van Dijk and Trienekens (2012) and Vellema et al. (2013), we position the interactions among actors in the partnerships at the crossroad of the "vertical" value chain and the "horizontal" network. The vertical dimension refers to the value chain the farmers are participating in which relates to supply and demand issues and to the market the farmers are part of. In value chain partnerships, the vertical dimension is chiefly represented by Northern-based actors. The horizontal dimension refers to the local socio-economic conditions and the network of non-economic actors and non-material conditions in which (local) actors participate, including their relationships with governmental bodies (Oosterveer, 2014).

From the farmers' perspective, Northern-based actors, including NGOs, backed by multinationals, represent a largely unknown part of the chain. Therefore, they conceived the projects initiated by Swisscontact, at least initially, as external initiatives (from the other end of the value chain). At the bottom of the value chain, the farmers need to make sense of these projects, decide on how to respond to, and handle them. Rather than by global market, the farmers' choices will be supported or constrained by their local social-economic and environmental conditions, preferences and social relationships. In brief, at the crossroads of these vertical and horizontal dimensions, global sus- 
tainability considerations are likely to meet different interpretations of reality that may not necessarily fit to one another.

Positioning these partnerships at the nexus of vertical and horizontal axes reveals some vital governance challenges to be addressed through interaction between the actors involved. In governance literature these challenges are often debated as potential strategic dilemmas that may impose the need to create synergies that enable the management of long-term systemic changes (see also Boons et al., 2012; Bush et al., 2014; Tallontire et al., 2011).

The first dimension of the challenges referred to in literature is how to link global economic objectives to local needs, values and interests. The partnership projects that we study here introduce a managerial, market-based approach to development, initiated by external actors. As has often been recognized, such initiatives are not power-neutral, but unfold within a context of existing resource and power asymmetries. Schouten and Bitzer (2015, p.175) address this as the 'context contingency' issue. In the literature, the recognition of this issue induced a (sometimes normative) debate about power imbalances in relation to the change promoted by the initiators of partnership projects. The main question to be addressed is who benefits and who loses as a result of the suggested change (for an overview see Bitzer \& Glasbergen, 2015). This issue to the problematic, even dilemmatic balancing between top-down interventions, a characteristic of partnerships initiated by Northern-based actors, and the room left for local interpretation and adaptation, deemed necessary to create local ownership and thus the effective implementation of the initiative.

The second dimension refers to discussions about the relationships between private and public responsibilities in partnerships projects. In partnership literature generally recognizes that the trajectory of private governance cannot be addressed without simultaneously considering the trajectories of public governance (Mayer \& Gereffi, 2010). Gulbrandsen (2012), for example, suggests that private standards and public policies can reinforce each other, particularly in cases where the state depends on private activities to realize its public objectives. Glasbergen (2013) shows that private sustainability standards need political backing and alignment in governments to become legitimate. The FAO (2014) also refers to potential synergies that can be effectuated through hybrid forms of governance in which voluntary standards interact with public regulations and institutions. Therefore, we assume that to effectively work in Indonesia, the partnerships need to adapt to the local regulatory conditions in order to align private initiative with public policies. Government support is necessary to open avenues for sustainable change. However, such support needs to be realized in a fragmented power structure where different levels of government with different stakes in the process of change are involved. Notwithstanding their different stakes, these multi-level governmental bodies need to align their practices among them. The question is how governments can get 
involved in the partnership projects in a way that allows them to develop capacities to sustain changes at the farmer's level and to preserve the advantages in the long run.

The third dimension refers to governance as a collaborative learning process in which the aim is to develop a shared understanding of reality and the activities that are needed (Ansell \& Gash, 2008). The partnership projects we study are faced with the challenge of reconciling divergent interests, and representing the economic imperative of trade in cocoa and non-economic social and environmental values to which this imperative relates. This reconciliation process includes the framing of sustainability in cocoa farming, which is an inherently normative process and rooted in real world problems with different sets of values and moral judgments (Robinson, 2004). Trade-offs may easily occur when dimensions of a concept are competing. This is of course inherent to the concept of "sustainable development" that aims to juxtapose social, environmental and economic objectives (Matzdorf \& Müller, 2010), without too much sustainability between these. Klapwijk et al. (2014) define conditions that make trade-offs ubiquitous, such as managing land with multiple ambitions and goals in mind, constrained resources, and conflicts between the goals of the different stakeholders. Therefore, a central dilemma in sustainable change processes comprises the choices that need to made in practice, i.e., what value dimensions of sustainable cocoa production need to be prioritized, probably at the detriment of the others and why.

\subsection{Research methods and research field}

This chapter applies an interpretative research methodology to a comparative casestudy design. Interpretative researchers take the existence of multiple interpretations of reality as a given and regard meaning-making as key to the scientific endeavor. The aim is to interpret events, that is, to understand how actors make sense of events and why they do so. According to this approach, understanding and interpretation originate from interactions between researcher and the researched (Schwartz-Shea \& Yanow, 2012; Yanow \& Schwartz-Shea, 2014).

Our starting point is a reconstruction of the Theory of Change underlying the partnership projects. This reconstruction is based on an analysis of partnership documents and interviews with the program director and field coordinators of the partnerships. Next, we use the aforementioned strategic dilemmas as different lenses to analyze the practices of the partnership projects. Our interactions with the research field were conducted from December 2014 to April 2015 and included semi-structured interviews, document analysis, a focus group, and observations. 
First and regarding the semi-structured interviews, respondents were chosen through purposive sampling. We interviewed the program director and the field coordinators of Swisscontact to obtain information about the background and the development of the partnership projects. Subsequently, we interviewed informants from (local) government-agencies and companies who have been engaged in the implementation of the program. In total we interviewed 43 respondents: 26 government officials and staff from the national, provincial, and district governments; 7 staff members from Swisscontact; 3 representatives from donor organizations and companies; and 7 other actors in the Indonesian cocoa sector and projects, such as the Cocoa Sustainability Partnerships (CSP), a sustainability standard body and a cocoa community forum in Sulawesi. In the interviews, we focused on questions related to the partnership projects. Interviews covered the perception of the involved actors on the projects as an external initiative; their perception of implementation problems; the engagement with various actors, including local governments, the role of involved actors, and the anticipated future of the projects. In sum, the interviews mainly informed us about how the projects' governance functioned in practice. These interviews form the main source of data of this research. From the analysis of the recorded and categorized interviews, we were able to comprehend the different view of actors and how they relate to each other.

Second, we analyzed public documents about the cooperation between Swisscontact and government agencies. Annual reports and work plans issued by Swisscontact were important to understand the progress of the projects in each district and the role of implementing actors. In addition, we also analyzed two kinds of documents from governmental bodies: The Strategic Plan and the Report of Accountability Perfomance of the Government-Agency (LAKIP) of Forestry and Estate Crops. From the analysis of the public documents, we were able to comprehend how the actors deal with the strategic dilemmas and what they consider to be the core of problems in the cocoa sector. For example, to comprehend the perspective of the governments on the cocoa development, we analyzed the Strategic Plans from 2013-2018 of the Forestry and Estate Crops Agency of the Districts of Parigi Moutong and Mamuju, the District of North Luwu for the years 2010-2015, the Report of Accountability Perfomance of the Forestry and Estate Crops Government-Agency (LAKIP) of the District of Parigi Moutong, Mamuju, and North Luwu in the years 2013 and 2014. These documents helped us to understand the engagement and contribution of the government in and to the projects. We also analyzed statistical documents on cocoa land-use and productivity that reveal trends in cocoa production in Sulawesi. This helped us to indicate the achievement of the projects so far.

Third, we also conducted a focus group discussion (FGD) with a "Tallusikambi" farmer group in the Mamuju district, West Sulawesi. This farmer group consists of alumni of the SCPP Field School. Their chairman is a key farmer, appointed by Swisscontact to dissemi- 
nate information from SCPP. The FGD took place on the $10^{\text {th }}$ of March 2015 and was attended by 21 farmers. During the FGD we discussed benefits and achievements of the SCPP for farmers and the role of governments in the project. Farmers also shared their concerns and expectations about the prospective determination of the project by Swisscontact. The information from the discussion was essential to comprehend the position of farmers in the program and their perception towards the field school.

Lastly, we observed activities and meetings like the Training of Trainers (ToT) for key farmers in the North Luwu district, South Sulawesi, and interactions between facilitators, government officials and participants. This information was used to complete the data, particularly for completing our understanding of the farmers' perspective.

We conducted our comparative case-study in Sulawesi, which is the most important cocoa producing area in Indonesia. Sulawesi covers approximately $70 \%$ of the national cocoa production (Ministry of Agriculture, 2014). Our research took place in three districts in three provinces. Although the project areas in each province spread over more than one district, we restricted our analysis to one district per province (see Table 3.1).

Table 3.1 The implementing actors of SCPP in the researched areas

\begin{tabular}{clll}
\hline Project No. & Province & \multicolumn{1}{c}{ Regency } & \multicolumn{1}{c}{ Partners } \\
\hline 1 & West Sulawesi & Mamuju & $\begin{array}{l}\text { Local governments, SECO, Kingdom of the Neth- } \\
\text { erlands, IDH, ICCRI, Syngenta, BT Cocoa, Nestlé }\end{array}$ \\
2 & Central Sulawesi & Parigi Moutong & $\begin{array}{l}\text { Local governments, SECO, IDH, ECOM } \\
\text { Local governments, SECO, IDH, Rainforest Alli- } \\
\text { ance, MARS Inc. }\end{array}$ \\
\hline
\end{tabular}

Source: Swisscontact report (2012).

The site selection was based on the diversity of the participating actors and the progress of the projects. Mamuju was chosen because it became a pilot project location. Here, the Indonesian Coffee and Cocoa Research Institute (ICCRI) coordinated a project to develop experimental farms. The Parigi Moutong project has the least numbers of partners due it's vulnerability for social conflicts, which may affect the implementation of the project. In North Luwu the project collaborates with Rainforest Alliance (RA) to support sustainability certification of cocoa.

\subsection{The theory of change underlying the partnerships projects}

In this section, we analyze SCPP's strategies through reconstructing their underlying Theory of Change (Anderson, 2005; Vogel, 2012). A ToC is not a scientific theory, yet the concept refers to an amalgamation of visions, ideas, conceptions, wishes and hypotheses that (policy) practitioners have about the causal processes and mechanisms through 
which change occurs as a result of (policy) programs. We use the ToC as a heuristic tool to identify and discern different elements of Swisscontact's program and practices. ToCs have ontological, normative and strategic features, i.e., about what reality is, why reality may be problematic, and how problems should be solved respectively. As will become clear below, these three aspects are intermingled. Our reconstruction reveals the following characteristics:

- First, within the projects, the reality of cocoa production is largely framed as an economic problem. Low productivity and poor quality are considered the main problems that should be solved by improving the knowledge and skills of farmers. A core target of the program is to achieve productivity levels of at least $1,000 \mathrm{~kg} / \mathrm{ha}$ per year, which is two times higher than the current level of production.

- Second, it is assumed that increasing profitability and enlarging the scale of cocoa-related businesses will enhance household incomes, living quality, the creation of new jobs, and subsequently the development of the regional economy. The program also aims to encourage cocoa smallholders to apply sustainability standards and certifications, which is believed to enhance the long-term prospects of the Indonesian cocoa sector.

- $\quad$ Third, the SCPP sees the engagement of private actors, who need reliable cocoa supplies for the survival of their industry, as essential for the effectiveness of the program. private actor engagement could link farmers directly to the market.

- Fourth, it is assumed that the farmers' knowledge-base and capacities regarding good agricultural practices, pest management, post-harvest handling, and business or managerial matters, are essential to realize SCPP's objectives. Training includes private sector officers and governmental representatives, in particular the so-called extension officers (see below) who are directly involved in assisting local farmers in their production processes.

- Last, collaboration with (local) governments is regarded essential to enhance the implementation of the program. This relates to the previous point, as the involvement of extension officers requires an official cooperation with governmental agencies. Based on the agreements, the governments are also responsible for the continuation of the program, which they are supposed to adopt and integrate into their policies after determination of the project (Swisscontact, 2012, 2013, 2014). 


\subsection{The first challenge: balancing the global and the local}

The initiators of the partnership projects perceive low productivity and low quality as the main problems of the cocoa sector. Through the projects, they intend to ensure the supply of good quality cocoa beans. In addition, these global actors regard farmer capacity essential to improve quality and productivity. However, at the producer level farmers perceive a different economic reality.

\section{Lack of capital is seen as the most urgent problem}

The degree to which farm land is maintained by the farmers is influenced by the farmer's capital. Although the partnership projects provide knowledge to improve farmer's capacity to better till the land, they do not solve what the farmers see as their main problem: the lack of capital to invest in, and improve, the farm. As long as this problem is not solved, it is unlikely that local conditions in the cocoa sector will be sustainably improved, as expressed by an official from the Provincial Estate Agency,

Many cacao projects coming to this region neglect the issue of economic strengthening. We expected that the management they brought, would lead to improved welfare. What I have seen so far however, are only trainings. But these trainings cannot solve the real problem. Indeed, farmers do have better knowledge, but their financial ability is still limited. Therefore, they are still unable to improve their farm (23 February 2015).

Limited capital to invest in the cocoa farm is also mentioned by farmers in the focus group discussion:

The Swiss NGO gave us knowledge about better farming and marketing, which we consider comprehensive knowledge. However, not all farmers directly apply the lessons learnt into their daily farming practices because they lack capital. We expect to develop a kind of cooperative to help farmers in collecting capital to invest in their farms, but this is also not easy as we need more capital to establish a cooperative (10 March 2016).

\section{Lack of short-term economic profit}

For farmers, achieving a higher income is important. By targeting a productivity of at least $1,000 \mathrm{~kg} /$ ha per year, the projects offer the prospects of a higher income, which is supposed to attract farmers to participate in the activities. For farmers, however, this prospect does not resonate a short-term economic opportunity and implies the careful 
maintenance of their cocoa plants for quite some time, before they can observe an increase in productivity. Although they are attracted to the prospect of an increasing income, the deferred profit averts them from participating in the projects. For farmers, selling their crops to middlemen is still a better option to quickly earn cash money than selling it to the trader with certain requirements.

\section{The farmers are seeking the economically most attractive commodity}

Farmers do not have advanced knowledge to fully understand the causes of low productivity and quality. They also lack a sense of leadership and entrepreneurship needed to maintain farmer organizations. Many farmers easily lose their interest in their farm and instead of improving their cocoa farming they prefer to shift to other cash crops when these crops promise higher profits, as indicated in some interviews:

In Mamuju, West Sulawesi, cocoa-land areas decrease in size, because many farmers shift their land to oil palm and patchouli plantations. Many farmers also give up because they cannot fight against the pests and diseases attacking the cocoa plants (Staff of the District Forestry and Estate Agency, 2 March 2015).

Cocoa in Parigi, Central Sulawesi is a specialty of this district; however, in the last years due to old plants, the production decreased. From the farmers' point of view, a higher price is needed to maintain their cocoa farms. Because they do not have enough capital to improve their farm, it is more interesting to shift their land to other commodities (the NGO's field coordinator, 13 March 2015).

Approximately $70 \%$ of the cocoa export comes from South Sulawesi, particularly North Luwu; however, the cocoa area here is decreasing in size. A large portion of non-productive land has been transformed into rice fields or other commodities after being confronted with pests and diseases. The tendency of South Sulawesi farmers to easily shift their land results from the higher prices for other commodities in the market, such as palm oil and patchouli. When cocoa prices are good, everyone plants cocoa, but when the price goes down, farmers easily shift to other commodities (Staff of the District Forestry and Estate Agency, 31 March 2015).

Table 3.2 shows the decline in cocoa land area and production in all three regions, with the exception for productivity ( $\mathrm{kg} / \mathrm{ha}$ ) in Mamuju and Luwu where we observe an increase when comparing levels in 2010 with levels in 2014. 
Table 3.2 Cocoa land area, production and productivity in the three research areas

\begin{tabular}{cccccccccc}
\hline \multirow{2}{*}{ Year } & \multicolumn{3}{c}{ Land area (Ha) } & \multicolumn{3}{c}{ Production (Ton) } & \multicolumn{3}{c}{ Productivity (Kg/Ha) } \\
\cline { 2 - 10 } & Mamuju & Parigi & Luwu & Mamuju & Parigi & Luwu & Mamuju & Parigi & Luwu \\
\hline 2010 & 69,214 & 65,548 & 56,238 & 27,373 & 43,566 & 33,900 & 782 & 647 & 829 \\
2011 & 65,499 & 61,739 & 51,246 & 26,870 & 35,649 & 33,185 & 807 & 599 & 710 \\
2012 & 61,580 & 70,073 & 46,184 & 29,370 & 40,634 & 32,691 & 836 & 688 & 700 \\
2013 & 60,983 & 69,656 & 35,765 & 20,383 & 52,968 & 21,200 & 802 & 477 & 960 \\
2014 & - & 67,656 & 34,252 & - & $37,104 *$ & 21,238 & - & 548 & 976 \\
\hline
\end{tabular}

Source: Ministry of Agriculture (2010-2014); Central Bureau of Statistic (2010 - 2014). (-) data is not available; *) temporary data.

\section{Only a limited group of farmers reached}

The partnership projects focus on an empowerment approach through the training of trainers (ToT) and farmer field schools (FFS). ToT is targeted at key farmers (village leadfarmers of farmer groups) and extension officers. During the training, the key farmers learn about good agricultural practices, nursery management, post-harvest processing, top grafting techniques, and are given an introduction to sustainable cocoa certification and good business practices. Moreover, as they are responsible for spreading this knowledge to other farmers, they are also taught in the area of facilitation and presentation skills (Swissconta, 2012, p. 11). The activity of ToT is followed by FFS. In the FFS, farmers obtain the technical and practical skills needed to improve the farm productivity. Usually, the FFS takes place once a week for every farmer group with 25-30 farmers participating. Our research shows that not all assisted farmers in the projects can apply the newly acquired knowledge to their daily practices. This is partly due to the already mentioned capital requirements, but also to a lack of motivation. In addition, since the projects are limited to selected farmer groups, they only reach a small part of the farmers in Sulawesi, which are not the most vulnerable ones. Swisscontact began the selection process with identifying potentially motivated farmers in designated areas through village officials, and the extension offices in the sub-districts. Requirements determined by Swisscontact were a minimum land area of 0.5 ha with 300 trees, the availability of a farm for a demonstration plot, and a clear organizational structure of farmer groups. This selection procedure, however, is questioned by local actors, particularly the district Forestry and Estate Agency, as expressed in the interview with one of them:

We want the NGO to assist and develop farmers from scratch, not to assist farmers whose farms are already in a good condition. I feel that what they do in this project is looking for the better farms, establishing farmer groups, then making up and reporting it into a good publication (31 March 2015). 


\section{No changes in power structures}

As mentioned above, the projects forecasted an economic profit for participating farmers. The projects encourage farmers to establish and improve their organizational capacity to improve their position in the value chain. Strengthening farmer groups, however, is not easy due to internal and external constrains faced by the farmers. Our research indicates that the effectiveness of the farmer groups depends on the motivation of the leader and the members. However, even with a very motivated leader, as in one of our cases, it is often difficult to motivate the members to better maintain their cocoa farm. One reason for this lack of motivation is the fragmented farm land, with cocoa plots that are often far away from the village where the farmers live, which makes it difficult to practice the labor intensive farming. An external constrain relates to governmental policies. For instance, although subsidized fertilizer is available in theory, the cocoa farmers have only limited access to it in practice as the regulations are not very transparent and the majority of the government budget is attributed to rice paddies.

We see that the projects do not necessarily create a stronger bargaining position for the farmers in the value chain. Farmers in the partnership projects are still in a rather powerless position, as they hardly influence on the cocoa prices predominantly set by the buyers. Hence, farmers easily take a realistic opportunity to transform their cocoa plantations into other crops such as oil palm, corn, and patchouli, especially if fellow farmers have already done so successfully (Antara \& Effendy, 2009; Saleh, 2010).

\subsection{The second challenge: balancing public and private}

The partnership projects are part of the largest public-private cocoa partnership in Indonesia, bringing together multinationals, a research institute, an NGO and Indonesian governmental agencies at various administrative levels. In Indonesia, every project funded and implemented by foreign organizations must be formally acknowledged by the national government. However, our research reveals many challenges related to the involvement of the government.

\section{Fragmented responsibilities}

A legal basis of the partnership projects was set out in the cooperation-agreements between Swisscontact and district governments in 2012, which marked the start of the implementation. Swisscontact cooperated with two governmental bodies in every district: The Forestry and Estate Agency (Disbunhut) and The Agency of Agricultural Extension. Both governmental bodies work on cocoa on a farmer level, and can therefore support the projects. The district Disbunhut played a role as a facilitator and provided a 
database, technical staff, and funds for an assistance program. While the agency of agricultural extension played a role in assigning the extension officers to participate in the ToT of the projects.

Shortly after the formal start of the projects, the projects came to the next level of coordination following the Memorandum of Understanding (MoU) between Swisscontact and the Ministry of Home Affairs (MoHA) under the umbrella of the Community Economic Development Program, signed on June $14^{\text {th }}$ 2013. The MoU was needed since SCPP operated in areas that were spread over many districts in two large islands, which made SCPP formally become a "national project". The MoHA attempted to establish a coordination mechanism by bringing in responsibilities for provincial governments. The coordination responsibility at the provincial level was supposed to be handled by The Regional Development and Planning Agency (Bappeda), which applies also at the district level ${ }^{1}$.

In the project's scenario the MoHA played a role as a regulator and a facilitator. The regulatory role results from Indonesian regulation, in which the presence of Swisscontact, as an international NGO in Indonesia, must be in accordance with the Regulation of the Ministry of Home Affairs No. 15, 2009 regarding Guidelines for Cooperation between the Ministry of Home Affairs and Non-Governmental Organizations. Under the Ministry of Home Affairs, Swisscontact coordinates with the Directorate General of Regional Development as they have similar interests in regional economic development. The facilitation role refers to connecting Swisscontact and the projects to local governments. In the table below we summarize the roles of public and private actors in the three projects under scrutiny.

Table 3.3 The role of public and private actors in the field

\begin{tabular}{|c|c|c|}
\hline Involving actors & Institutions & Roles \\
\hline NGO & Swisscontact & $\begin{array}{l}\text { - Implementing activities related to the projects. } \\
\text { - Informing governments and partners about the } \\
\text { progress of the project. } \\
\text { - } \quad \text { Reporting to partners and publication. } \\
\text { - Coordinating the stakeholders. }\end{array}$ \\
\hline $\begin{array}{l}\text { Private } \\
\text { companies }\end{array}$ & Mars, Nestlé and Ecom & $\begin{array}{l}\text { - Funding the projects. } \\
\text { - Locating cocoa bean buying stations in the operation- } \\
\text { al regions. } \\
\text { - Providing technical staff and agronomists to support } \\
\text { the activities in the field. }\end{array}$ \\
\hline
\end{tabular}

\footnotetext{
${ }^{1}$ According to the mandate of Law No.32, year 2004 on Local Government, every provincial government is a representative of the central government in terms of coordination, guidance and supervision of the district/city area. Consequently, the role of the provincial government is crucial to connect the central government with the district/city governments.
} 


\begin{tabular}{|c|c|c|}
\hline $\begin{array}{l}\text { National } \\
\text { government }\end{array}$ & $\begin{array}{l}\text { The Ministry of Home } \\
\text { Affairs }\end{array}$ & $\begin{array}{l}\text { - Facilitating between the Swiss NGO and local gov- } \\
\text { ernments and communicating the projects to the lo- } \\
\text { cal governments' officials. } \\
\text { - Monitoring and evaluating the projects. }\end{array}$ \\
\hline \multirow[t]{2}{*}{$\begin{array}{l}\text { Provincial } \\
\text { government }\end{array}$} & $\begin{array}{l}\text { The Regional Development } \\
\text { and Planning Agency } \\
\text { (Bappeda) }\end{array}$ & $\begin{array}{l}\text { - } \text { Unclear }^{2} \\
{ }^{*} \text { Bappeda in Central Sulawesi facilitates the meeting } \\
\text { between the NGO and the district government. }\end{array}$ \\
\hline & The Estate Agency (Disbun) & $\begin{array}{l}\text { - Providing a work place for the NGO. } \\
\text { - Providing data and information required by the NGO. }\end{array}$ \\
\hline \multirow[t]{3}{*}{$\begin{array}{l}\text { District } \\
\text { government }\end{array}$} & $\begin{array}{l}\text { The Regional Development } \\
\text { and Planning Agency } \\
\text { (Bappeda) }\end{array}$ & $\begin{array}{l}\text { - Arranging the coordination meetings with other } \\
\text { government agencies. } \\
\text { - } \text { Providing officers and assistance budget. } \\
\text { - } \quad \text { Attending the opening of the project activities. } \\
\text { - Monitoring and evaluating. }\end{array}$ \\
\hline & $\begin{array}{l}\text { The Forestry and Estate } \\
\text { Agency (Disbunhut) }\end{array}$ & $\begin{array}{l}\text { - Providing technical staff. } \\
\text { - } \text { Funding the operational costs of extension officers. } \\
\text { - Providing data and information required by the Swiss } \\
\text { NGO. }\end{array}$ \\
\hline & $\begin{array}{l}\text { The Agency for Agricultural } \\
\text { Extension }\end{array}$ & $\begin{array}{l}\text { - Assigning their extension officers to participate in the } \\
\text { project activities. }\end{array}$ \\
\hline
\end{tabular}

Source: Research data, $2015 .^{3}$

With many public agencies and various private actors involved, a transparent allocation and distribution of responsibilities is crucial. As one can draw from the table, each agency has specific roles and makes specific contributions into the projects based on its competencies, capabilities and resources. However, the fragmentation of the latter is very likely to create tensions between the public and the private actors or within the public sector, e.g. between government bodies at different levels.

\section{Different organizational cultures}

Our research particularly reveals such a tension between the provincial governments and the NGO. At the provincial level and according to the MoU, two agencies are supposed to support the projects: The Regional Development and Planning Agency (Bappeda) and the Estate Crops Agency. These agencies have the same name and function as their counterparts at the district level. In the three districts, the provincial Estate

\footnotetext{
${ }^{2}$ Based on the main duty and function of Bappeda, plans (e.g. activities and budget) from local governmental agencies must go through Bappeda. It also coordinates planning between provincial and district office. It has the power to "cut" or "grant" budget for horizontal institutions. However, it has no clear competency for controlling district/regency offices (the Regulation of Government (PP) Number 41 year 2007).

${ }^{3}$ The table is based on the research data collected in the three districts. This information captures the real practices of the implementation of the $2013 \mathrm{MoU}$.
} 
Agency provided work space for the NGO's staff members. In practice, however, the role of the provincial agencies was rather unclear; although they were expected to facilitate and monitor the projects, there was no intensive communication between the NGO and these provincial governments. This was mainly due to the fact that provincial governments were involved a year later than the district governments. Therefore, the regional development and planning agency at the provincial and district levels responded quite late in fulfilling its role in the projects. This was recognized by one of the officials of this agency:

We knew that we (Bappeda) were involved when the national team visited us in October 2014. During that meeting, we were shocked to know that we should play a role based on the Memorandum of Understanding. These documents were not in our hands before, that is why we did not do anything relating to the project. They (The NGO and the district Disbunhut) were supposed to tell us in the beginning about the project. We thought that this project was between the district Disbunhut and the NGO only (2 March 2015).

In addition, all government agencies requested regular reports on the projects' activities and progress from Swisscontact. They also asked for coordination meetings in order to align the projects with government programs. Swisscontact, however, focused on the projects' achievement in terms of profit and sustainable cocoa, as mentioned by the field coordinator of the NGO during our interview:

Coordination with the governments is still weak although we have attempted to communicate and coordinate as much as possible. Our organizational culture is quite different; the government is too bureaucratic. While we focus on the work in the field, the government officials are difficult to meet since it is difficult to match with their schedule (18 February 2015).

This issue is highly representative for public-private partnerships (Brinkerhoff \& Brinkerhoff, 2011; Shapiro \& Rosenquist, 2004). Both parties face difficulties in obtaining and sharing information about progress since they have different opinions on the what's and why's of reporting due to their diverging interests. While government agencies ask for information to fulfill administrative and bureaucratic obligations, the NGO focuses on concrete project achievements. These differences in cultures of public and private organizations easily result in miscommunication.

Unclear relationships between government agencies 
The lack of coordination also applies to the public sphere itself, both between different governmental agencies, such as the Disbunhut and the Bappeda, and within each agency between the head and staff. As we observed in the second project region, the frequent change of the Head of the Disbunhut had a negative effect on the information provision. Staff members and Agency's new director were hardly informed about the projects. This personnel rotation happens frequently, as it is part of the decentralization policies, with frequent changes in political leadership and interests in the region as a result. As a consequence, the NGO staff had to explain the partnership projects to the government staff over and over again, which negatively influenced the progress made.

The Ministry of Home Affairs (MoHA), through the Memorandum of Understanding with Swisscontact, has a monitoring and evaluation system for the projects. The MoHA expected the coordination in each territory to be handled by the Bappeda. Better internal communication among government agencies would make the coordination more effective albeit to relieve Swisscontact's burden of reporting to all governmental agencies. The NGO expected this latter function to be handled by the Bappeda as stipulated in the MoU.

We built an intensive communication strategy through regular progress reports and meetings with the district governments because our implementation areas are in those districts. We expected that the district governments would disseminate the progress reports to other related governmental agencies under their authority, however, this did not happen (19 January 2015).

\section{Conflicting private and public policies}

Another tension regards conflicting policies between public and private actors. In project number three this became manifest in the different purchasing policies for cocoa beans. The implementing partner in this district prefers to purchase wet beans from farmers. This preference however, contradicts with the Regulation of the Ministry of Agriculture Number 67, year 2014, regarding quality and marketing requirements that necessitates farmers to ferment their beans before selling them, as the fermentation is supposed to create added value and a better price for the farmers. The district Disbunhut faced difficulties to get this policy internalized as farmers prefer selling wet beans. Farmers believe that they gain more profit with wet beans compared to fermented beans, as selling wet beans saves energy and time. Based on our interviews with the field coordinator of the NGO and the official of the district Disbunhut (31 March 2015), we calculate that farmers' profit from wet beans is at least $15 \%$ higher than from dry beans. Conflicting regulations like the one referred to above, still persist and may even intensify in the future as the government cannot effectively interfere with business issues. In the end, farmers risk to be mostly affected by this divergence and confusion. 


\section{Partnership objectives weakly integrated in government policies}

The involvement of Indonesian government-agencies should ensure that the partnership projects align with the government's program regarding the development of the cocoa sector. This alignment comprehends a joint problem definition, avoiding overlapping work, and ensuring long-term effects of the projects. Based on our public document analysis, we found that the projects are not (yet) integrated in the annual program of the governments. The governmental reports do not mention the projects at all. Moreover, although cocoa can be considered to be a specialty in the three regions, there are not many governmental activities focusing on the development of this sector. This is caused by the fact that the agency's attention and budget for agriculture needs to be shared with other commodities, such as food crops and livestock, which are generally prioritized over estate crops such as cocoa in national, provincial and district policies.

The first project region is an exception here as the Performance Report written by the Forestry and Estate Crops Agency in 2014 mentions two programs focusing on cocoa. The first program focusses on improving farmer welfare and provides extension, training, marketing, and the development of demonstration farms. The second program focuses on improvements in agricultural production and provides agricultural facilitation, such as fertilizer, farmer field schools for cocoa farmers to improve human resources, and to provide good quality seedlings. These programs are in accordance with the strategic plan of West Sulawesi Province, as explained by an official of the Provincial Bappeda:

The main contributor to economic welfare in our province is the plantation sector, i.e. cocoa and palm oil. As a new province, the first priority (2006-2011) is to lower the number of people in poverty, in particular cocoa farmers, because in our region cocoa farmers are dominant. By improving cocoa farmers' welfare, we expect that poverty will decrease (3 March 2015).

Furthermore, our analysis of the public documents of the three regions shows that the governments apply a technical approach to address improvements in the cocoa sector, e.g. programs providing training, field schools, and seedlings. As a consequence, and given the governments' limited budget, they only reach a small number of cocoa farmers. Therefore, one might question the effectiveness of governmental policies in solving the aforementioned problems in the cocoa sector. Engagement with private actors through the cocoa projects could potential fill the mentioned gaps in the governmental policies, but this has not been realized yet. 
The partnership projects should not be evaluated on their short-term achievements only, but also in terms of their contribution to the institutionalization of long-term changes. The involvement of local governments should ensure this institutionalization. As the projects are temporary, local governments have the responsibility to continue the spirit of the projects based on the MoU after determination of the projects. This is in accordance with the instruction of the MoHA, stating that local governments should have an exit strategy - a strategy to adopt the projects into their regional policies when the projects have expired. However, only one local governmental agency has prepared this strategy - the district Disbunhut of Mamuju, West Sulawesi (the first region). In its program for 2015, it utilizes farmers' skills gained from attending the field school meetings of the project. In 2015 the district Disbunhut changed its method from distributing seedlings towards establishing nurseries and providing equipment, so that farmers can actually apply the learnt skills in the field of top grafting the seedlings. In doing so, the government encourages farmers to take part in the process and it is expected that the farmers will feel more responsible in maintaining their farm. This may be a first sign of readiness to continue the cocoa sustainability project in the region after the SCPP project expires.

\section{Low involvement of extension officers}

In their attempt to connect the global initiative to the local level, the projects involved agricultural extension officers; staff members who are responsible for assisting farmer groups in villages related to agricultural practices. Their role can therefore be conceived as boundary workers as they transfer and translate knowledge from Swisscontact to the farmers (McMillan, 2011; Tisenkopfs et al., 2015). Their involvement seems an adequate strategy from the NGO to help them in training farmers in the field schools. It is also a strategy to ensure the sustainability of the projects, given their position as governmental officials who are supposed to continue to assist farmers (Swisscontact, 2014: 15).

However, although extension officers and local governments will continue to work with farmers in the field, there was some doubt among our respondents whether the extension officers would keep focusing on cocoa farming after expiration of the projects, because their responsibility (and therefore maybe priority) covers other crops that are regarded more important, such as rice paddies. During the FGD, cocoa farmers expressed their disappointment about the inactive role of government extension officers in their villages, particularly in providing farmers with information about governmental agricultural programs. Consequently, the cocoa farmers sensed that they already receive less attention from the government than farmers with food crops. In an attempt to fill the gap resulting from the inactive role of agricultural extension officers at the producer level, many NGOs and private companies nowadays assign their agronomists and field 
officers to train cocoa farmers about good agricultural practices. This private extension, which is embedded in many partnership programs, could help farmers to improve their cocoa farm.

\subsection{The third challenge: balancing values}

The third dilemma is to find a balance between economic, environmental, and social aspects of a change towards sustainability. As mentioned before, the Theory of Change underlying the projects frames the cocoa problem as predominantly economic problem. This problem definition shapes the activities of the projects that focus on increasing production and improving quality.

\section{The subservience of environmental issues}

Although the ToC mainly refers to the economic aspects of cocoa production, environmental issues are embedded in at least three main activities, namely training the farmers and field schools, the rehabilitation of cocoa plants, and certification schemes (Project report, 2012).

First, in the trainings and field schools, farmers participate in outdoor activities to learn about good agricultural practices. The training includes post-harvest processing to meet quality standards. One of the topics in the training and field schools is the sustainable use of fertilizer. For example, as stated by farmers in the FGD, one of the benefits of the NGO-driven training was that they learnt that certain fertilizers do not benefit cocoa plants and might even endanger the environment. Second, the rehabilitation of cocoa plants: most cocoa plants in Sulawesi are old plants, about 20-25 years old, which make them vulnerable to disease that decrease productivity. Therefore, farmers are taught grafting techniques and encouraged to establish nurseries.

Third, the projects also promote sustainability certification of cocoa. During the trainings and field schools, farmers are introduced to sustainability certification schemes, i.e., UTZ-certified, Rainforest Alliance and Fair Trade. Some principles mentioned in the certification schemes, for example good agricultural practices and the use of fertilizers, are taught to the farmers. Through certification, environmental aspects of cocoa farming can get more prominence. However, from our FGD and observations, we infer that environmental issues can only get meaning for farmers if they are framed as economic prospects. Farmers prioritize the economic aspects of farming and their social relationships (see below) over environmental issues.

This prioritization issue is also visible in palm oil and coffee certification schemes. According to Hidayat, Glasbergen and Offermans (2015), palm oil smallholders perceive certification as an economic tool to pursue a better livelihood rather than a tool to en- 
sure a more sustainable agriculture. Other values than economic ones are less appreciated by smallholders, except when they result in economic benefits. Moreover, since there are many coffee certification schemes in Indonesia, farmers prefer the ones that offer a tangible price premium (Ibnu et al., 2015). Economic prospects are therefore the single most important factor for farmers in their decision to join a specific certification scheme. Regarding Indonesian cocoa, there is no clear evidence that certification schemes create economic benefits for farmers, as many traders pay and hold the certificate, and there is no transparency on how the premium price is distributed to farmers (Abdulsamad et al., 2015; Moriarty et al., 2014). For these reasons, cocoa farmers hesitate to participate in certification schemes unless they are ensured by the economic benefits that they will receive later.

The projects are committed to facilitate farmers in the process toward certification. The NGO perceives certification as a levier to improve the competitiveness of the Indonesian cocoa sector in the global market. Certification schemes function as a guarantee for consumers that production takes place in a more sustainable way. Farmers could benefit by receiving a premium price once their farm is certified and this may improve the long term prospect of cocoa production. Moreover, as reported by the NGO, the certification process also has created job opportunities, for example in farmer organizations and the Internal Control System (ICS). Among the three locations mentioned in this chapter only the third project in North Luwu has already been certified by Rainforest Alliance (RA). Here, Rainforest Alliance (RA), together with Swisscontact and PT Mars, is supporting cocoa farmers in maintaining their cocoa farms in accordance with sustainability standards. In this district, the implementer of the Internal Control System (ICS) for RA is CV Marewa 45 which is a business unit under the "Masagena" cooperative. Since 2013, the "Masagena" cooperative, receives supportfrom VECO, PT Mars and Wasiat (a local NGO). An earlier project than SCPP has thus obtained a Rainforest Alliance certificate. This certificate is accredited to 1,074 farmers with a total land area of 1,306 hectares of cocoa plantation (VECO Indonesia, 2014, p.11). In North Luwu the holder of the RA certificate is the farmers' cooperative. In their second year of RA certification, farmers already experienced advantages from the certificate, such as access to better marketing channels, the receipt of a price premium and a formal contract that allows selling the certified beans directly to PT Mars. Being informed about the advantages of certification by their fellow farmers, many farmers are now interested in joining the cooperative to become certified, even though it is rather difficult to apply the standards of RA certification (Interview with CV Marewa, 3 April 2015). Through the SCPP projects, the representatives of CV Marewa 45 and RA actively encourage farmers to comply to the principles of good agricultural practices.

Farmers' enthusiasm in responding to certification can also be seen in the first project location in Mamuju, West Sulawesi. In this district, farmers are given information 
about sustainability certification by Swisscontact. Despite the 90 requirements, farmers are encouraged through the economic advantages that they will get later. By the end of 2015, farmers were preparing to be examined by an external auditor from UTZ certification with the idea that at least 1500 farmers can get certified (FGD, 10 March 2015; Swisscontact, 2015).

However, in the last decade, many cocoa farmers have shown less interest in cocoa cultivation and preferred transforming their cocoa farms into oil palm plantations. The projects play a role in convincing farmers to continue their cocoa plantations. Through the projects, farmers became aware that cocoa is more environmentally friendly than oil palm. Oil palm demands more water and change to other commodities is much more difficult in the case of oil palm since the soil will generally be too dry and depleted to be used for other crops.

Moreover, the government officer from the district Disbunhut provided additional information about the pros and cons of oil palm compared to cocoa for farmers:

The conversion from cocoa to oil palm has become one of the threats in West Sulawesi. We try to defend our cocoa plantations by promoting programs on cocoa. We also consider environmental issues. We realize that farmers do not have proper information about oil palm. They think that oil palm is more profitable, but this is not always true. Farmers only follow others with the idea that oil palm does not require intensive care like cocoa. However, many farmers start to regret their decision, because cultivating oil palm is costly and it is difficult to sell the fruits individually ( 9 March 2015).

\section{The value of persistent social relationships in economic transactions}

One of the projects' strategies is the creation of a shorter supply chain. By bringing trader companies in the projects farmers can directly sell their beans to these trader companies instead of middlemen or local collectors, who are by-passed. This provides farmers with an opportunity to gain better and more competitive prices. The representative of a buyer company in the first region explained the advantages of selling cocoa beans directly to traders as follows:

We create advantages for assisted farmers who sell their beans here. First, we provide a free sack with a logo of the project brand. Second, farmers receive a premium fee every three months (approximately $2 \%$ of the average price per kilo). Third, reward points are given to farmer groups based on their selling, which can be accumulated on a yearly basis and exchanged for farming tools. Fourth, farmers will get a higher price for fermented beans compared to unfermented beans. In addition, to- 
gether with the NGO we provide farmers with equipment to improve the quality of the cocoa beans and marketing (4 March 2015).

And yet, although assisted farmers are assumed to choose for the shorter chain, some of them still prefer selling to middlemen because transactions with middlemen have more value than only in economic terms. A strong social relation exists between farmers and middlemen, either through kinship or through a debt legacy. Moreover, middlemen are usually open to provide cash money whenever the farmers need it. These debts can be paid back in the future with their crops. As a consequence, the farmers in the projects face a dilemma between economic rationality and social considerations. The opportunity to increase their profit might go at the detriment of their social relations with their neighborhood middlemen.

\section{Gender concerns difficult to implement}

Similar to other typical development projects, and related to social values, the projects promote the inclusion of women in cocoa farming. The projects have targeted $20 \%$ female participation in agricultural practices (Swisscontact 2013: 14). This gender concern is integrated in the activities of the farming field schools and women receive material about family nutrition and finance. Generally, women's role in cocoa production is rarely recognized, which is also the case in Sulawesi. Although women are highly involved in pre and post-harvest work, they hardly participate in farmer groups or other public organizations. As we found in the ToT activity in the third project location, only one female representative of a farmer group attended the event among thirty male representatives. Most farmer groups are already established with a male leader. An exception we found in the FGD in the first project location where the majority of members of the "Tallusikambi" farmer group were women. The objective of women inclusion in farmer groups is that women play an important role in encouraging their husbands in maintaining their farms and in supporting the household economy. Based on the observations in the two locations above, we learned that there is a work division between women and man in cocoa farming. Mostly men take part in public activities, such as meetings and trainings, while women are more active in farming practices in the field.

\subsection{Conclusion}

This research investigated the strategic issues and dilemmas of (sustainable) cocoa production in Indonesia, focusing on three districts in three provinces in Sulawesi Island, covering the 2012 to 2015 period. While we should be careful with generalizations, the 
partnership projects we studied are similar to other projects initiated by Northern-based businesses and NGOs in the Indonesian cocoa sector.

The overall assessment of the projects depends on the scope and criteria one starts with. From a narrow interpretation one might easily conclude that the projects are doing rather well, as they reached a lot of farmers, organized training and achieved that the participating farmers are better prepared to improve their production. However, this picture changes when we take a broader scope on the problems of the cocoa sector and the opportunities for long-lasting changes. The low quality of cocoa beans and low productivity can be considered essential problems of cocoa farming in Indonesia. The Theory of Change underlying the partnership projects recognizes this problem definition, and connects to it through its emphasis on training, organizational capacity building, and building sustaining relationships with governments.

Our first observation is that our conceptualization of the three governance challenges is valuable to understand the complex problems the projects face in practice. The way in which these strategic dilemmas are handled, largely determine whether a global partnership between Northern NGOs and businesses will result in a well-functioning partnership with relevant actors at the local level, and therefore, will induce the envisioned system changes at the production level in the South. Our research revealed tensions in the search for synergy with regard to each of three governance challenges.

On the global versus local dimension we observe tensions between framings of the problem by the Northern initiators of the projects and the farmers. While the initiators stress training, the latter emphasize the need for capital and short term profit. The prioritization of economic values also plays a role in farmers' attitude towards sustainability certification.

On the public versus private dimension we observe divergent organizational cultures, miscommunication, coordination failures and problems with allocation of responsibilities. Similar coordination problems are visible among Indonesian government bodies as the various administrative layers display varying political priorities and political interests in the cocoa sector.

Regarding the reconciliation of diverging values and interests, we observe that the partnership projects tend to underestimate or even ignore the traditional relationships at the local level. While the shorter chain strategy envisages an elimination of the role of middlemen and local collectors, farmers need them to get instant money. Moreover, their relationships with middlemen are more than only economic in nature; they are an essential part of the community's social interactions.

Concerning the institutionalization of a system change our research results into a rather pessimistic conclusion. First, because the reach of the projects is limited, and only represents a small selection of cocoa farmers. Marginal farmers outside the project areas, who encompass the majority of cocoa farmers in Sulawesi, are not reached. Sec- 
ond, intuitively and from our empirical data, one can anticipate that farmers will still easily shift to other crops in the next future if the return on investment of other commodities is higher than cocoa. Third, we recognized a lack of ownership of the public actors. It is very hard to anticipate them to translate the projects' objectives in government policies. An illustration of this issue regards the future role of extension officers as they will certainly continue to work with farmers, also when the projects expire. As the extension officers' responsibilities do not solely cover cocoa, but also other agricultural commodities, their attention can be expected to shift easily to other crops, which is presently already the case.

Moreover, land area and yields in most Sulawesi regions tend to decline along with the implementation of the projects. It is hard to see how the projects could successfully intervene in this process. One can conclude that the rather managerial approach by the Northern actors, quintessentially based on the assumption that the economic problem of low productivity and low quality can be solved through training, is not sufficient to effectively handle the issue at stake. Therefore, it neglects too much that the persistent problem of land use change relates to other problems underlying the tensions in the governance dilemmas, such as the short-term economic interests of the farmers, their weak bargaining position in the economic process, the lack of commitment of government-agencies, and the institutionalized social relationships of the farmers.

The analyses based on our diagnostic framework seem to be policy relevant as they may help to localize and better understand the persistent problems regarding externally initiated partnership projects in collaboration with Southern governments and local producers.

An important issue for further research is to look for opportunities for improving the role of extension officers as intermediaries between the global projects, the national agricultural policies and the farmers, particularly regarding sustainability issues. Our research indicates a change from the traditional public extension work to private extension. This brings up the question on how to assess and evaluate this change in terms of its implications for the traditional public role in extension work and the process towards a more sustainable production of agricultural commodities.

The continuation of the researched projects, and alternatives for such types of partnership projects refer to other important issues for further research. Mid 2015, Swisscontact signed a contract with MCA-I (Millennium Challenge Account for Indonesia) for additional funding for another three years (2015 to 2018) to reach more farmers and give them better access to finance. Such a project funding seems to be rather easily available. However, we also observe the existence of rather new, bottom-up Indonesian partnership initiatives, particularly between producers, research institutes, local governments and traders that aim to improve the economic and social welfare of Indonesian farmers (Mawardi et.al., 2006; Soemarmo et.al., 2009; Virgiano, 2012). It seems 
paradoxical that these initiatives to better connect farmers to the global value chain, have to develop without large-scale funding. We suggest that a comparison between the governance challenges of the two types of partnership projects can further improve our knowledge about the pathways towards a more sustainable cocoa farming. 
Chapter

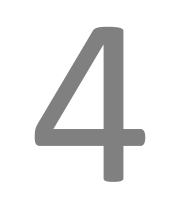

The Mediated Partnership Model for sustainable coffee production: Experiences from Indonesia 


\section{Abstract}

This chapter demonstrates how a bottom-up agricultural development project, rooted in the practices of the smallholders and their (local) networks, might relate to global sustainability standards and certification schemes. Such an initiative starts with the economic interests of the farmers and may result in sustainability certification afterwards. An approach was investigated to implement more sustainable coffee production at the local level in Indonesia - the Mediated Partnership Model (Motramed). We conceptualize this model, initiated by an Indonesian research institute, as a form of collaborative governance to create a new, more sustainable management practice. We particularly focus on four critical mechanisms in the partnering process: defining a common problem, building trust, exploring collaborative advantages, and establishing a leadership role. Empirical research was conducted in three regions: Bali, Flores, and Java. In conclusion, we define several critical factors that need to be addressed to further develop similar bottom-up partnerships for more varied agricultural commodities.

Accepted as:

Wijaya, A., Glasbergen, P., \& Mawardi, S. (forthcoming). The Mediated Partnership Model for sustainable coffee production: Experiences from Indonesia. International Food and Agribusiness Management Review 


\subsection{Introduction}

A more sustainable production of agricultural commodities is generally seen as being in the interest of the livelihood of farmers in the South (Bitzer et al., 2008; Giovannucci \& Koekoek, 2003). This interest is particularly reflected in the steady growth of sustainability standards and certification schemes initiated by Northern-based business and NonGovernmental Organizations (NGOs) or partnerships between them (Bartley, 2010; Fuchs et al., 2011; Bitzer \& Glasbergen, 2015). As external initiatives from the top of the value chain, these schemes are channeled downwards to the bottom of the chain as new conditions for production (Giovannuci \& Ponte, 2005). At the bottom of the chain, the producers need to make sense of the standards, decide on how to respond, and handle them given local socialeconomic circumstances and preferences (see also Vellema et al., 2013; Marin-Burgos et al., 2015; Schouten et al., 2016; Hatanaka, 2010; Bitzer et al., 2013). Participation in these market-based initiatives is voluntary, but it has gradually become a prerequisite for access to parts of the global market. Howeer, it is still doubtful whether Northern-based certification is the most effective way to improve farmers' livelihood (Abdulsamad et al., 2015; Van Rijsbergen et al., 2016).

This chapter shows how bottom-up agricultural development projects, rooted in the practices of the smallholders and their (local) networks, might relate to these external certifications from the North. In this chapter, we analyze such a project: Motramed (in English: Mediated Partnership Model), which is different from the former initiatives on coffee production, as certification standards are not a starting point for a change in the practices of coffee producers, but they may result from practices that are changed with the intention to improve the living conditions of the farmers first. Motramed was initiated in 2001 by the Indonesian Coffee and Cocoa Research Institute (ICCRI). ICCRI is a research center that specializes in the cultivation and processing techniques of coffee and cocoa commodities ${ }^{4}$.

Motramed is based on the following considerations (Mawardi et al., 2006; Soemarno et al., 2009; Virgioano, 2012; Hartatri and de Rosari, 2011). The first consideration is the idea that the farmers' income should be increased by improving coffee quality and shortening the marketing channel. The problems of low quality and a long supply chain are seen as interconnected, and therefore, improving both is regarded as an inseparable formula for improving the livelihood of farmers.

\footnotetext{
${ }^{4}$ ICCRI was established in 1911 and is located in Jember, East Java. Structurally, ICCRI is still part of the Indonesian government, under coordination by the Ministry of Agriculture, the Ministry of Research, Technology and Higher Education, and the Ministry of State-Owned Enterprises. However, in terms of its operational budget, ICCRI is a self-funding institution. ICCRI has a wide network, which was established from numerous collaborations and research projects with stakeholders, ranging from international to local organizations, research centers, companies and governments.
} 
Second, coffee quality should be improved through technology transfer. ICCRI has the responsibility of disseminating technology to the farmers. In Motramed, ICCRI introduces the procedure of wet processing (WP) of coffee cherries, which meets international standards. By following WP, farmers will gain added value from processed coffee that they do not gain by directly selling coffee without advanced processing (Mawardi et al., 2006).

Third, the marketing channel should be simplified by building partnerships between farmers and exporters. The long supply chain between farmers and exporters has resulted in an inefficient marketing channel. Because of this long chain, there is only small value for each player, of which farmers get the least value due to their weak bargaining position (Neilson, 2008; Astuti et al., 2015; Hartatri, 2016). Therefore, in Motramed, directly connecting farmers and exporters results in a shorter coffee supply chain. Thus, farmers will receive a higher price than they would when they sell to local traders or middlemen.

Although these considerations focus on economic improvement, Motramed also addresses social and environmental aspects in order to comply with sustainability principles. Motramed encourages farmers to work in collectivity by establishing farmer organizations. Through these organizations, it is easier to coordinate the activities of coffee processing, and collective marketing will create a stronger bargaining position for farmers (Mawardi et al., 2006). Motramed promotes shade tree applications and applies organic farming (Mawardi, 2009a). However, in the partnering process, economic aspects receive priority, as they are considered an incentive to encourage farmers and other actors to participate.

This study aims to contribute to our knowledge of the intricacies of implementing such a bottom-up partnership model to induce more sustainable production at the local level. We are particularly interested in the factors that are conducive and limit change. From our analysis, we aim to draw on lessons from similar initiatives to improve the economic position of farmers in the sustainable production of agricultural commodities at the local level. We first introduce an analytical framework. Next, we explain our research methods. In the subsequent section, we analyze a pilot project in Bali that developed into a model of change, followed by an analysis of two other Motramed cases. In the conclusion, we reflect on these findings.

\subsection{Analytical framework}

Herein, we conceptualize Motramed as a form of collaborative governance to create a new, more sustainable management practice. The term "collaborative governance" refers to the interactive process through which the changes in the production network will be realized. In the Motramed case, the actors involved in coffee production and trade need to create a new mutually beneficial relationship. In this process, they need to develop a common definition of the problems, a shared vision of the future, and com- 
mitments to activities that need to be employed. Van Tulder and Pfisterer (2013) refer to this kind of process as the creation of a "partnering space." A partnering space is a framework within which the positions and roles of actors from different societal sectors are considered in a collaborative arrangement. Through their interactions, the actors are assumed to be able to identify opportunities for aligned actions and build a synergistic relationship. In such a relationship, the actors realize more through cooperation than they are able to realize on their own. The concept of partnering space resonates with the view of Austin and Seitanidi (2012), who declared that creating value is the central justification for multi-actor partnering. They define collaborative value as transitory, and the enduring benefits are relative to the costs that are generated due to the interactions of the collaborators and those accrued by organizations, individuals, and society.

Based on these studies, we can analytically clarify the process and mechanisms that are instrumental and critical to Motramed as a partnering process. Most generally, we assume that this process includes generating the ability, desirability, and willingness to develop a new production network.

First, the actors involved in the production network must recognize a common problem. As Schruijer (1999, p. 2) observed, collaboration can only be created when a shared problem definition is developed. Regarding Motramed, there must be recognition of inefficient coffee production that is caused by existing production methods and connections to the market. A critical mechanism to create an accepted problem definition would be the transfer of knowledge and expertise regarding more promising production networks. According to Loconto (2016), mobilizing knowledge is fundamental to better linking small farmers with markets in developing countries and creating transitions to a more sustainable production network. Such knowledge transfer includes information on what to do, how to do it, when to do it, and why.

Second, the actors need to recognize their interdependent relations and the need for collaboration. Regarding Motramed, a critical mechanism is fostering trust among actors and commitment to cooperate in the change process. Trust particularly encapsulates an emotional argument, which is the reduction of feelings of risk and vulnerability in the partnering process. Trust is regarded as a significant component of collaboration in networks (Glasbergen, 2011). Trust diminishes the risk of opportunistic behavior in a relationship, increases the probability that actors will invest their resources and is supposed to stimulate learning and the exchange of information and knowledge (Klijn et al., 2010). In a trader-supplier relationship, trust includes recognition of the competence of the supplier to deliver the required quality and quantity of the product (Saad et al., 1999, p. 43). Everlasting trust for all is not instantaneously created. Building trust is a social process that needs to be managed, maintained and supported by positive experiences (Brewer and Haylarr, 2005; Glasbergen, 2011; Barroso-Méndez et al., 2016).

Third, the actors in the partnership need to recognize the advantages of cooperation, and these advantages should be regarded as long-lasting. The central mechanism should be the creation of collaborative advantage. Regarding Motramed, potential actors need 
to find advantages that they cannot achieve without the partnership (Brinkerhoff, 2002; Emerson et al., 2011). According to Glasbergen (2011), collaborative advantages must relate to resources, skills, and a balance between benefits and costs among partners. In this study, collaborative advantages will be analyzed by looking at the actors' interests in coffee production and how they distribute responsibilities among themselves in accordance to their capacity and resources.

Fourth, the functioning of an intermediary entity that fulfills a leadership role in the network is important. The leadership role denotes the capacity to bring the different actors together around the issue and to facilitate communication to take the partnership forward. Leadership is not something that comes naturally. As Huxham and Vangen (2000) observed, leadership is often thwarted by dilemmas and difficulties. Therefore, it requires abundant energy, skill, and personal attention to chaperone the cause and drive a partnering process forward. Leadership intervention tasks include appreciation or envisioning, convening, problem structuring, designing the process, reflective intervention, conflict handling, brokering and institutional entrepreneurship (Gray, 2007). Because participation in Motramed is voluntary, the leadership role occurs in a nonhierarchical context, which implies that it is mainly based on specific competences that are valued by the other actors.

The process of employing these mechanisms should be seen as an iterative and cyclical process rather than as a linear process. It is an empirical question as to how these mechanisms unfold in practice. Here, we take them as a 'lens' to study Motramed and the lessons that can be learned.

learned.

\subsection{Research methods}

This chapter applies a qualitative research approach to understand the evolvement of Motramed as a local partnership to induce more sustainable production of Arabica coffee at the producer level. We employed three main research methods.

First, semi-structured interviews were used to gain a comprehensive view of the actors in the process of collaboration to develop a new management practice through Motramed. The informants were chosen through purposive sampling. We first interviewed the initiator of Motramed, i.e., ICCRI's researchers. They led us to the key informants in each region, who were interviewed by snowball sampling in accordance with the need for data in the field (see Table 4.1). 
Table 4.1 Composition of informants

\begin{tabular}{clc}
\hline No & \multicolumn{1}{c}{ Institutions } & Number of informants \\
\hline 1. & Indonesian Coffee and Cocoa Research Institute (ICCRI) & 2 \\
2. & Farmer organization and cooperative & 12 \\
3. & The Estate Crops Agency (Dinas Perkebunan) & 5 \\
4. & Exporter & 3 \\
5. & Bank & 2 \\
6. & NGO and community organizations related to coffee & 4 \\
7. & Perhutani (State-owned enterprise on state forestry) & 1 \\
& Total & 29 \\
\hline
\end{tabular}

The semi-structured interviews were helpful to detect the informants' framing of coffee production problems. We also crosschecked the information that we had previously obtained from the informants. We sometimes conducted interviews more than once so that the informants could talk freely without interruption from other informants.

Second, we attended three meetings related to Motramed: two annual member meetings of cooperatives in Bajawa and Bondowoso and a coffee stakeholders meeting in Bondowoso. We collected information on the interaction patterns among the actors in the partnering process, focusing particularly on trust and commitment building and the role of leadership.

Third, we analyzed documents related to Motramed both from governmental bodies and ICCRI, such as the Memorandum of Understanding (MoU) in some regions, published reports of the implementation of Motramed in some regions, and the requirements books of Geographical Indications. We also analyzed statistical data for coffee production, productivity, land area and coffee prices to gather data regarding the changes that resulted from Motramed.

From 7 to 10 November 2015, we went to the Bajawa and Manggarai regions in Flores to conduct preliminary research with the aim of gaining a clearer picture of Motramed before finalizing the research framework. Then, from the end of December 2015 to March 2016, we completed our research in three different regions in Indonesia. We selected these regions based on specific features and the progress of Motramed. The first region is Kintamani, Bali, which was chosen as a pilot project that began in 2001. The second region is Bajawa, Flores, which applied Motramed in 2004. The third region is Bondowoso, East Java, which applied Motramed in 2011 with more stakeholders involved since the initiation of Motramed.

\subsection{Case 1: The pilot project of the partnering process in Kintamani, Bali}

In this section, we will analyze the partnering process based on the four mechanisms introduced in the previous section. The period of analysis covers the beginning of the partnership in 2001 until 2015. Originally, Motramed was not a model with a fixed de- 
sign, but it developed over time. The origin was closely related to the application of a Geographical Indication (GI) protection system ${ }^{5}$. A pilot project was initiated by ICCRI in cooperation with CIRAD (a French agricultural research organization) and was supported by the Provincial Estate Crops Agency of Bali (Disbun Bali). Kintamani, Bali, was chosen as the pilot project location because of its popularity as an Arabica coffee producer.

\section{Common problem definition}

Before the pilot project started, ICCRI had conducted a baseline study regarding the potential of Arabica coffee in Kintamani. This study showed that the price of Arabica coffee in Kintamani was lower than that of Robusta coffee, i.e. 5,200 IDR/kg for Arabica and 5,400 IDR/kg (USD 0.48) for Robusta (interview with the senior researcher of ICCRI), although Arabica coffee is generally regarded as being of higher quality. Consequently, farmers had lost their motivation to maintain their coffee plantations and preferred to change to tangerine trees, which offered more profit. This massive conversion became an environmental threat for Bali because Kintamani is a highland area and coffee plants have a function in preserving groundwater. The study concluded that the low prices were caused by the low quality and long supply chain at the production level. These basic problems were not only problems for farmers but also a concern of the local government. Therefore, it was necessary to attract more farmers and improve their coffee plantations through the creation of a price incentive. ICCRI concluded that this goal could be realized by building a partnership among the actors involved in coffee production. ICCRI played a role as a provider of knowledge regarding the improvement of coffee quality and disseminated this knowledge to the staff of Disbun Bali and farmers.

\section{Building trust}

It was not easy to convince farmers to participate in this partnership. At first, ICCRI and the staff of Disbun Bali purposively selected four potential Subak Abian (SA) ${ }^{6}$ - Kertawaringin, Triguna Karya, Bhaktiyasa and Ulian Murn - that showed a strong willingness to try the new technique of wet processing (WP) introduced by ICCRI. The staff of Disbun Bali explained how they tried to convince farmers to participate in the partnership:

\footnotetext{
${ }^{5}$ This system is part of Law No. 15, year 2001, regarding trademarks. Geographical indication (GI) is a sign that indicates the origin of products. Gl is important because geographical factors, including human and natural factors, result in specific characteristics and qualities. GI was created as a response against the misuse of geographical names by Japanese and Dutch companies (Mawardi, 2009a).

${ }^{6}$ Subak Abian (SA) is a traditional farmer organization that adheres to the Hindu philosophy of "Tri Hita Karana," which translates as three causes of happiness that can be obtained when one has a good relationship with God, other people and the environment. SA is involved in not only agricultural activities but also religion and social activities.
} 
Together with ICCRI, we worked on improving the understanding of farmers to change their habits from strip picking, which dominates green and yellow cherries, to fully red picking. We presented economic calculations to them showing that processing coffee will result in higher prices than directly selling coffee to local traders.

ICCRI also showed farmers how to better manage their coffee plantations. Farmers were not only persuaded by the economic advantages; the health aspects of the production process, e.g. a more hygienic process, also played a role. With more advanced knowledge, the farmers valued coffee more highly than they did before, and they even started to consume this high quality coffee themselves. Meanwhile, the government also supported farmers by establishing a processing unit for each SA and providing machines to these units. During the harvest period, ICCRI researchers and the staff of Disbun Bali intensively assisted farmers to ensure that they would comply with the standard operating procedures (SOP).

The next step was connecting farmers to exporters. Previously, farmers and exporters did not interact because exporters preferred to buy coffee beans from their suppliers. Many exporters were reluctant to directly interact with farmers. In their view, it was risky for their business because of the low quality of coffee and because farmers were reportedly unable to keep their commitment to an agreement (according to interviews with the exporter). Farmers were also anxious about trading with exporters because exporters might be deceitful in their pricing. Thus, their relationship was undermined by doubt and misunderstanding. However, the presence of ICCRI and the staff of Disbun Bali sufficiently assured both farmers and exporters of the value of initiating interaction between farmers and exporters.

ICCRI succeeded in inviting an exporter from France in 2002. However, this exporter did not buy coffee from the farmers because the quality did not yet meet the standards, as the farmers were still in the early process of learning WP. Later, in 2003, with CIRAD's network, PT Indo CafCo under the ECOM Group was willing to participate. Despite concerns about dealing with farmers, the Director of PT Indo CafCo was very interested in the Kintamani Coffee brand. ICCRI's intensive monitoring of farmers convinced him to take part in this partnership. Thus, PT Indo CafCo's trust was strongly influenced by the credibility of ICCRI as the mediator and the active role of Disbun Bali in supporting the farmers.

\section{Exploring collaborative advantage}

In partnering processes, all actors need to find long-lasting advantages that they cannot achieve without the partnership. These collaborative advantages can be analyzed by examining their interests and the distribution of responsibilities.

ICCRI, as the mediator in this partnership, had an interest in disseminating its research results to the community as part of their obligations as a research center. Their 
research results consisted of not only knowledge and skills regarding coffee but also agricultural products, ranging from seedlings to machineries. ICCRI observed an opportunity to expand its network in the coffee sector.

The local government's interest was to improve the regional economy through coffee farming, which was regarded as a potential area that could be developed. With this interest, the local government also expected that the increase in farmers' welfare would lead to the growth of other sectors, such as education and health. However, the agency did not have the ability to achieve this alone. By cooperating with ICCRI, the local government could achieve its goals. The local government also helped ICCRI disseminate its knowledge and agricultural products. The support of the government consisted of providing machines (some of which were bought from ICCRI), tools, technical assistance, and loans for farmer groups.

Farmers had an interest in earning a higher income. They were highly motivated to participate in the partnership if there was a price incentive for their work. Previously, farmers did not have much price-setting power because of the low quality of their coffee. After applying the WP technique, farmers could produce green bean coffee grade 1 with a good taste profile, as tested in the CIRAD and ICCRI laboratories ${ }^{7}$. Better quality led to a better price at the farmer level (see Figure 4.1).

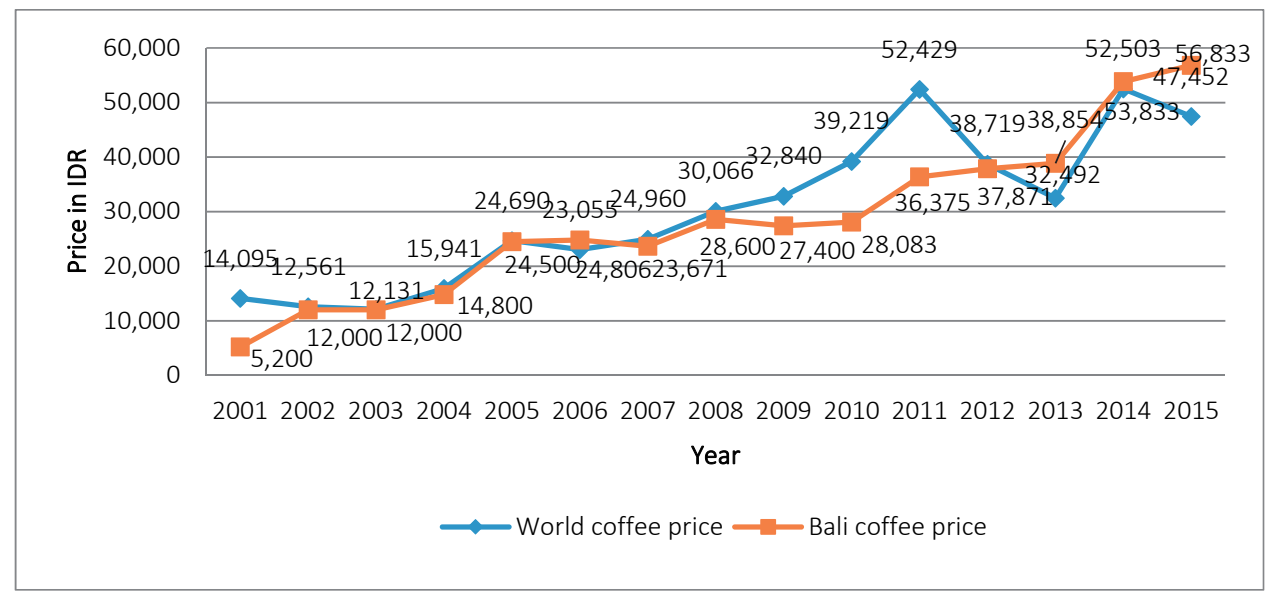

Figure 4.1 The price of Bali coffee compared with the world coffee price (Source: The Estate Crops Agency of Bali Province, 2015; Mawardi et al., 2006).

Figure 4.1 shows that in 2001, before the quality improvement program of Motramed had begun, the coffee price in Bali at the farmer gate was three times lower than the world coffee price. However, in the next few years, the Bali coffee price gradually increased and had a small margin compared to the world coffee price because of its

\footnotetext{
${ }^{7}$ Additional results from the laboratory test of Kintamani Arabica coffee can be found in Mawardi (2009b).
} 
improved quality. In 2006, the Bali coffee price was higher than the world coffee price by approximately $7 \%$, and farmers received a price premium. Although the discounted Bali coffee price fluctuated between $-0.8 \%$ at the lowest and $-30 \%$ at the highest from the world coffee price in 2002-2015 ${ }^{8}$, it still showed a large improvement since the initiation of Motramed. The price fluctuation was strongly influenced by the world coffee price and the currency exchange rate. During the partnership with PT Indo CafCo as an exporter, farmers received almost the same price as the international price ${ }^{9}$.

The increase in coffee price attracted more SA to participate in the program. They believed that by complying with the SOP of WP, farmers could earn a higher income. In the first two years, ICCRI and Disbun Bali only focused on four SA until farmers could produce better quality coffee. Afterwards, four SA were added each year for training and support in coffee quality improvement (CGIP, 2007). Although many more SA showed interest in the partnership, they could not all receive this aid due to the limited budget of the government.

The exporter's interest was to obtain a sustainable coffee supply with good quality and quantity. With this partnership, PT Indo CafCo obtained an agreed quantity that met its quality standards and the expectations from their overseas buyers. During the partnership, PT Indo CafCo contributed by allocating an assistance fee to ICCRI, offering their staff to monitor the processing in the field, and providing processing machines. In addition, PT Indo CafCo made an advanced payment if farmers had difficulties obtaining capital to start coffee processing. These contributions showed that the exporter understood the farmers' interest in obtaining a price incentive for their work. Without easy access to capital and machines, it would be difficult for farmers to improve their coffee quality.

In 2008, Kintamani Bali Arabica Coffee was awarded a Geographical Indication certificate, which was the first GI certificate in Indonesia, based on the Community of Geographical Indication Protection (CGIP) ${ }^{10}$. Although the GI certificate is not a commercial certificate for trading, it ensured that Kintamani Arabica coffee is a regional asset protected by law. The Gl certificate regulates the procedure of coffee production, processing, quality control, and marketing. This certificate added value to the Bali Kintamani Arabica coffee brand, as it became better known on national and international markets

\footnotetext{
${ }^{8} \mathrm{~A}$ more elaborate explanation of this chart is presented in Appendix A.

${ }^{9}$ The world coffee price in the chart uses the grade 1 price of the "Other Milds" coffee category from ICO (in which Indonesian Arabica coffee is part of Other Milds category), whereas the Bali coffee price is for unsorted beans at the farmer gate. If the farmer gate price is converted to grade 1, $10 \%$ needs to be added. Thus, the farmers were receiving a good price from PT Indo CafCo because they produced grade 1 Arabica coffee.

${ }^{10}$ CGIP, established in 2005, assisted in the process of obtaining a GI certificate, and it later played a role as supervisor of the quality of Bali Kintamani Arabica coffee. The members of CGIP include 61 Subak Abian (representing 3201 households) and 6 local coffee processors (with WP technique), and the local governments, ICCRI, CIRAD and PT Indo CafCo, which are are members of the advisory board (CGIP, 2007, p. 4).
} 
for its quality and unique taste. This certificate is an additional advantage of the partnership for all involved actors.

\section{On the leadership role}

Although there was no assigned leadership in this partnership, this role was taken by ICCRI. With its renowned reputation as an expert in coffee production and its understanding of the social, political and economic context within which production occurs, ICCRI could link the farmers, government and exporters and could facilitate communication among them. Leadership thus implied facilitating a partnering process based on the creation of consensus on a preferable future for all stakeholders in the coffee production process.

During the partnering process in Kintamani, several obstacles influenced the progress of the partnership. First, PT Indo CafCo decided to end its coffee trading in Bali after six years (2003-2009). Although their main reason was a change in internal policy caused by a change in director, it was also clear that the exporter no longer observed collaborative advantages that made it worthy to continue the partnership, as explained by a former staff member:

We closed our coffee trade in Bali in 2009 because the director resigned. The new director did not want to continue the partnership because it was complicated, and it did not give much profit or quantity. Another reason was that the company wanted to focus on its main area in Medan, Sumatera, which could produce a larger quantity. We may get a lot of profit through such a partnership, but it takes a long time to reach that level.

Second, after PT Indo CafCo left Bali, the local market became overly dynamic and competitive among buyers. Farmers preferred to sell their coffee to buyers with the highest offer. Consequently, farmers started to sell smaller quantities individually and this put the spirit of collectivity at risk. Meanwhile, ICCRI could not continue its work because there was no financial support from PT Indo CafCo or the local government ${ }^{11}$. As commented by a farmer representative:

When PT Indo CafCo was still here, Kintamani coffee was a leading commodity. We won a national contest in coffee taste. Unfortunately, a few farmers now no longer follow the SOP because there is no guarantee from the buyers. We think that there

\footnotetext{
${ }^{11}$ Although ICCRI formally ended its leadership role in the partnership, it still maintains an informal relationship with farmers and local governments. For example, ICCRI still consults regarding coffee quality and the coffee market through mobile phone contacts with the farmers and Disbun Bali.
} 
is no company like PT Indo CafCo, which gave us advantages as long as we produced good quality coffee.

Third, farmers hesitated to continue the spirit of Motramed through the strategy of "one-door marketing" developed by the provincial government of Bali. This strategy aimed to stabilize coffee prices, regulate supply and demand, maintain commitment to quality and control its distribution so that unfair competition could be avoided (according to an interview with the director of CGIP Cooperative). The government initiated the cooperative of CGIP, which was expected to bring back the spirit of collectivity among SA and become a representative of coffee farmers to sell Bali Kintamani Arabica Coffee. However, not all SA were willing to participate in collective marketing through the CGIP Cooperative, with one reason being that farmers were reluctant to pay fees to the cooperative, even though the members would ultimately benefit from the fees.

\section{Evaluation}

Previously, the farmers in this region were not well organized and were dependent on local collectors, and they sold unsorted, low-quality beans. The local government, i.e. Disbun Bali, did not have the knowledge to intervene. Motramed changed the old production network to a new one and created a fixed relationship between farmers and the exporter. The local government received advanced knowledge regarding coffee processing from ICCRI, and the governmental staff was able to train farmers. This partnering process was possible due to the leadership role of ICCRI and its close cooperation with the local government. After a decade of Motramed, the market in Bali is now more developed, produces better-quality coffee and is more dynamic. The positive side is that many buyers come to Bali to purchase good-quality coffee in smaller quantities than the exporter did. This creates competition among buyers, and farmers have more options to sell their coffee to the preferred buyer. However, this also has a negative side, as farmers tend to go back to an individualized system of trading. Farmers have gradually become more reluctant to participate in collective marketing through the CGIP Cooperative. A positive side effect is that the local government of Bali adopted this model and applied it to other commodities, such as cashew nuts and Robusta coffee, in other districts.

\subsection{Intermezzo: the philosophy of Motramed}

Based on the successful implementation of the pilot project in Kintamani, ICCRI conceptualized the Motramed partnering process into four stages, as shown in Figure 2 below. ICCRI also presented the model at the national level at the Ministry of Agriculture and at the national coffee symposium in August 2006. 


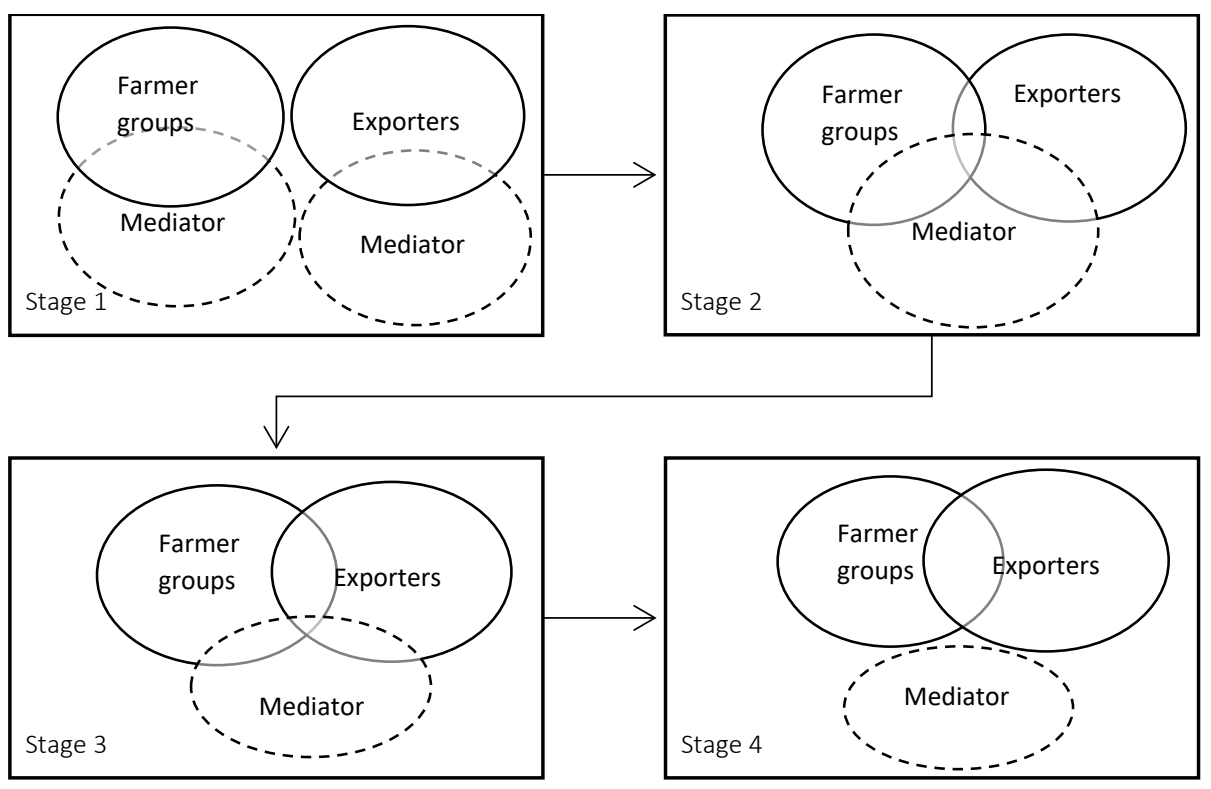

Figure 4.2 The implementation stages of Motramed (Source: Mawardi et al., 2006, p. 84).

Figure 4.2 shows three main actors in Motramed: farmer groups, coffee exporters and the mediator. In the first stage or pre-partnership, there are only relationships between the mediator and farmer groups and the mediator and exporters. Farmers and exporters do not have any relationship yet. The mediator explores the possibilities of developing a partnership. In the second stage, the mediator begins to connect farmer groups to exporters. The mediator transfers knowledge to farmers about quality improvement, while exporters can explore their advantages. In the third stage, the relation between farmer groups and the exporter is stronger. Here, the mediator plays a role as a consultant in the process. In the fourth stage, the independence stage, the mediator reduces its involvement and plays a role as a consultative actor.

The mediator plays a crucial role as a mobilizer of the other actors. The mediator should be a neutral actor who has credibility and is trusted by all actors involved in coffee production. The mediator should have expert knowledge on coffee and needs to be competent to create liaisons among the main actors in coffee production. In this model, the mediator is ICCRI, because the ICRRI has advanced agricultural technology related to coffee production and is a respected actor in the sector. Moreover, the mediator needs to fulfill several roles: conducting a baseline study to explore the possibilities of a partnership, finding exporters as a partner, building trust between farmers and exporters, providing training for farmers, monitoring the process of knowledge transfer, controlling coffee quality, and sustaining negotiations to achieve mutual agreement between farmers and exporters. In carrying out these roles, the mediator always coordinates with relevant governmental agencies. 
Although it is not stated clearly in the model, ICCRI cannot perform this work without an active supporting role of local governments through their budget allocations, human resources, and facilities. Local governments, at either the provincial or district level, can be considered a client who, due to their limited capability, asks ICCRI to be their consultant in coffee development. Their involvement in Motramed is supposed to help them develop their regional economy. However, the level and form of involvement of local governments in Motramed may vary from one region to another.

\subsection{Case 2: The operationalization of Motramed in Bajawa, Flores}

Valuable lessons obtained from the Kintamani case improved the implementation of Motramed in Bajawa, Flores. Initially, the Provincial Estate Crops Agency of East Nusa Tenggara (ENT) in 2004 asked ICCRI to explore the possibility of implementing the model in some Arabica coffee regions on Flores Island, including Bajawa and Manggarai. In its feasibility study, ICCRI found similar problems to those in Kintamani. The old management practice in Bajawa was worse than that in Kintamani, as farmers did not have any knowledge of post-harvest and coffee processing, and this lack of knowledge resulted in a much lower coffee price than that in Bali. In Bajawa, District of Ngada, farmers only received approximately 1.100-1.500 IDR, or 0.15 USD/kilogram for Arabica coffee cherries $^{12}$, which is four times less than the coffee price in Bali before the partnership was implemented. Farmers did not have any bargaining power because the quality was very low and the prices were set by local traders or collectors on the local market.

Only the District Estate Crops Agency of Ngada (Disbun Ngada) actively supported Motramed and officially started the partnership with ICCRI in 2005. The objective of Disbun Ngada was to improve coffee farmers' welfare and to protect Bajawa coffee as their regional asset ${ }^{13}$. Disbun Ngada, which was supported by the provincial government of ENT, provided two budget allocations: assistance for the operational costs of ICCRI and facilities for farmers, including assisting farmers in the process.

We observed that the new management practice in Bajawa was much better organized than the one in Kintamani. Although the same technique of coffee processing used in Kintamani was applied in Bajawa, the network of farmer groups was stronger. Farmers received training regarding coffee quality, group dynamics and the economic system of togetherness to improve the organizational capacity of the farmer groups. In Kintamani,

\footnotetext{
${ }^{12}$ Based on interviews with the senior researcher of ICCRI and the staff of the District Estate Crops Agency of Ngada.

${ }^{13}$ Previously, coffee from Bajawa was widely known as Ruteng coffee (a sub-district in Manggarai) because all the post-harvest processing was performed in Ruteng, and Bajawa was only a supplier of coffee cherries. Consequently, there was no economic advantage to process coffee in Bajawa (interview with the staff of Disbun Ngada).
} 
although ICCRI did not recognize the need for this training, improving farmers' organizational capacity resulted in the acquisition of a crucial asset. Bajawa farmers were culturally different because they were very active, open to change and eager to develop Arabica coffee.

As a start, two farmer groups that were willing to receive assistance and try something new were selected: Fa Masa and Suka Maju. Earlier, many farmers refused to participate because they did not want to become the subject of an experiment, as expressed by the staff of Disbun Ngada:

At the beginning of our work, we often heard from farmers that they did not need us, and they asked us to leave. However, we are grateful that we have indomitable leaders (i.e. ICCRI researchers and the head of Disbun Ngada) who encouraged us to continue to help farmers because of the farmers' ignorance on how to produce better coffee.

With the support and promise of ICCRI and the government, farmers were encouraged to continue the process. In fact, the farmer groups quickly improved the quality of their production. Disbun Ngada and ICCRI developed a processing unit ${ }^{14}$ in each farmer group. The training courses and the processing unit were new for Motramed, and they were developed based on the evaluation of Kintamani's experience.

As a next step, ICCRI tried to invite exporters to join Motramed. Previously, there were no exporters in this region because yields were low and transporting and shipping costs were high. The first large exporter to enter Flores Island was PT Indokom Citra Persada, which ICCRI successfully invited. Involvement with Motramed was a big decision for this company, as they used to buy coffee from a supplier, and building a partnership with farmers was something new. However, the reputation of ICCRI in the coffee sector was seen as a guarantee of success, and PT Indokom felt confident with the support of the local government in Motramed.

In addition to creating trust, all respective actors needed to explore the advantages of participating in Motramed. Applying Motramed in the Bajawa region was a challenge because of the lack of resources, such as bad infrastructure and inadequate human resources, which were common in the Eastern part of Indonesia. ICCRI's interest was to make Motramed as successful as it was in Bali despite the unfavorable conditions. This interest matched well with the interest of the local government to promote their region, improve regional income by increasing farmers' income and develop Arabica coffee. The farmers also obtained many advantages from participating in Motramed, such as new knowledge and skills in coffee processing, economic calculations, and negotiations with

\footnotetext{
${ }^{14}$ In Bahasa, this is called Unit Pengolahan Hasil, or UPH. This UPH functions as a business unit to support collective processing and trade with the exporter.
} 
buyers, and they became more aware of coffee quality. One of the farmer groups expressed this awareness of quality as follows:

When farmers process coffee based on the SOP, the prices never decline. Farmers do not want to go back to the traditional methods. "Quality is a must!" We really feel the advantages of producing good quality coffee.

PT Indokom understood the effort made by farmers to improve coffee quality. Therefore, after the farmers succeeded at producing green beans with good quality, PT Indokom gave them a better price than the local market. Table 3 below shows some remarkable coffee prices in Bajawa since Motramed was implemented.

Table 4.2 The price history of Flores Bajawa Arabica Coffee

\begin{tabular}{|c|c|c|}
\hline Year & Price & Notes \\
\hline 2004 & $\begin{array}{l}1,100 \text { IDR per } 1 \mathrm{~kg} \text { of red } \\
\text { cherries (equal to } 6,600 \mathrm{IDR} \\
\text { per kg green bean) }\end{array}$ & $\begin{array}{l}\text { Farmers directly sold red cherries at the local market, as they did } \\
\text { not yet know how to process coffee. }\end{array}$ \\
\hline 2005 & $\begin{array}{l}17,500 \text { IDR per } 1 \mathrm{~kg} \text { of green } \\
\text { beans }\end{array}$ & $\begin{array}{l}\text { Processed coffee with a better quality. While the price of green } \\
\text { beans at the local market was } 12,000 \text { IDR, Bajawa farmers re- } \\
\text { ceived a } 30 \% \text { higher price from PT Indokom. }\end{array}$ \\
\hline 2007 & 20,500 IDR per $1 \mathrm{~kg}$ & Green beans (unsorted) \\
\hline 2013 & 27,500 IDR per $1 \mathrm{~kg}$ & This was a good price, as the world coffee price fell this year. \\
\hline 2014 & $\begin{array}{l}11,750 \text { IDR per } 1 \text { liter of wet } \\
\text { parchment bean (equivalent } \\
\text { to approximately } 45,000 \text { IDR } \\
\text { per } 1 \mathrm{~kg} \text { of green beans) }\end{array}$ & $\begin{array}{l}\text { Starting this year, farmers sold wet coffee parchment to PT } \\
\text { Indokom. Wet parchment is processed coffee that has a } 30 \% \\
\text { moisture content. This solution (i.e., wet HS) was decided on } \\
\text { because of ( } 1 \text { ) high rainfall that did not support the drying pro- } \\
\text { cess and ( } 2 \text { ) farmers' limited capital, whereas aid from the gov- } \\
\text { ernment was insufficient for all farmer groups. Farmers still } \\
\text { benefited from this price because they did not have to do all the } \\
\text { processing. }\end{array}$ \\
\hline
\end{tabular}

Source: The Estate Crops Agency of Ngada District, 2015; Soemarno et al., 2009; and interviews with Bajawa actors 2015.

PT Indokom obtained advantages from Motramed as well. First, the supply chain was shorter because the company purchased directly from farmers. Second, PT Indokom acquired coffee with assured quality, which suited their consumers' standards. PT Indokom encouraged farmers by giving aid such as machines and tools to support coffee processing. At this stage, the relationship between farmers and the exporter was drawing closer over time. Frequent meetings to discuss problems and solutions were possible. For example, because of the excellent quality, PT Indokom asked for a larger quantity; however, the farmers encountered difficulties related to labor, capital and natural 
factors. The win-win solution consisted of selling dried parchment coffee (dried HS) ${ }^{15}$. By selling dried HS, farmers benefited from time savings in processing but still received a good price.

The district government showed a strong commitment and was very supportive in controlling the processes in each farmer group. In the meantime, the local government started to transfer the Motramed model to other commodities.

Moreover, other coffee actors in Bajawa made greater efforts to develop the Arabica coffee commodity by obtaining sustainability certifications and the Gl certificate, thus institutionalizing a more sustainable production process. PT Indokom helped Bajawa farmers become organic certified and send its Internal Control System (ICS) team to assist farmers in preparing their farms. In 2007, Bajawa coffee farms obtained organic certification from the USDA and next obtained Rainforest Alliances certification in 2008. According to the farmer groups, the sustainability certification not only positively impacted health and the environment but also farmers' income ${ }^{16}$. For example, when the world coffee prices fell in 2013, Bajawa coffee farmers still received a good price from PT Indokom because of its quality and the growing demand by international consumers for a sustainability guarantee.

Additionally, the Bajawa coffee stakeholders established the Community of Geographical Indication Protection (CGIP) for Bajawa Flores Arabica Coffee and prepared the requirements book to apply for the GI certificate ${ }^{17}$. In 2013, Bajawa Arabica coffee was awarded the GI certificate by the Indonesian government. With this certificate, the Flores Bajawa Arabica coffee brand is now better prepared to preserve the coffee tradition in Bajawa.

\section{The follow-up of Motramed}

After ICCRI reduced its role as a mediator, the district government, together with other stakeholders, such as PT Indokom, the CGIP Bajawa, and an NGO that became involved, further worked on the development of the coffee sector.

First, the CGIP Cooperative, which was more structured than the one in Kintamani, began to function as a one-door-marketing system of Flores Bajawa Arabica Coffee. In price negotiations, PT Indokom and the CGIP Cooperative sat together to discuss the prices and tonnages. Collective marketing through the CGIP Cooperative strengthened

\footnotetext{
${ }^{15}$ Dried HS is processed coffee beans that still contain parchment (shell horn). If the shell horn is removed with huller machines, the product is called green beans (CGIP Flores Bajawa, 2011: 89).

${ }^{16}$ Based on interviews with the director of PT Indokom and the ICS staff.

${ }^{17}$ The requirements book contains the history of Bajawa coffee, coffee processing, community, etc. By 2011, CGIP members consisted of 25 farmer groups that produced red cherries (representing 600 household farmers), 14 UPH, and 1 roaster (CGIP Flores Bajawa, 2011: 14).
} 
the farmers' position in negotiating the price with the company. The cooperative became a symbol of a shared commitment of the coffee stakeholders to develop Bajawa. For every kilogram of coffee sold through this cooperative, farmers or UPH must contribute a marketing fee of approximately 500 IDR (or 0.5 cents). With this marketing fee, the CGIP Cooperative has collected 66 million IDR that will be used to prepare the Fair Trade accreditation.

Second, a new Memorandum of Understanding (MoU) was concluded in 2015 between the district government of Ngada with the CGIP cooperative, PT Indokom, Bank of East Nusa Tenggara, VECO Indonesia and ICCRI. More actors became interested in joining this MoU due to the achievements of Motramed in Bajawa. VECO Indonesia, as an NGO, will for example play a facilitation role for farmers in preparing for the Fair Trade certificate through capacity improvement. The Bank of East Nusa Tenggara will help farmers by providing access to loans for coffee processing. With this MoU, the program was more focused on on-farm management training to increase the production and expansion of coffee land area than the previous MoU. Motramed's main focus was on post-harvest quality improvement; there was not much attention to on-farm improvements. Consequently, land area and production tended to stagnate over the past few years (see Table 4.3).

Table 4.3 Growing area, production and productivity of Bajawa Arabica coffee 2010-2014

\begin{tabular}{ccccc}
\hline No. & Year & Growing area (ha) & Production (Ton) & Productivity \\
\hline 1 & 2010 & 5677 & 1996 & 739 \\
2 & 2011 & 5651 & 2584 & 766 \\
3 & 2012 & 5627 & 3047 & 811 \\
4 & 2013 & 5510 & 3298 & 867 \\
5 & 2014 & 5720 & 3448 & 825 \\
\hline
\end{tabular}

Source: The Estate Crops Agency of Ngada District (Disbun Ngada), 2015.

Third, the District government of Ngada issued local regulation number 6, year 2016, regarding the protection of Bajawa coffee as a regional asset. This regulation aimed to further protect Bajawa coffee and to confer more benefits to the community. It covers issues such as land protection to avoid chemical farming inputs and diversion of land use, collective marketing and labor during the harvest period.

\subsection{Case 3: The further development of Motramed in Bondowoso, East Java}

Bondowoso, East Java, applied to Motramed in 2011. The partnering process in this case differs from that of the previous regions. The partnership model was introduced to the Provincial Estate Crops Agency in East Java in 2006, immediately after the development in Flores. ICCRI attempted to contact officials at the provincial level, assuming that it 
might be easier to cover many districts at once. However, this approach was never continued. Similar to what occured in Bali and Manggarai, the district governments were not willing to support a program from the provincial government. Although this was not a major constraint in the implementation of Motramed, it influenced the progress and continuation of the partnership. In this section, we particularly address what is different from the previous regions in the partnering process.

The first difference concerns the 2011 Memorandum of Understanding (MoU) of the partnership, which was signed by seven actors and is valid for five years and operationalized in annual work plans. The new actors had different interests. The Bank of Indonesia was interested in maintaining the stability of the Indonesian currency. One method to accomplish this was to increase the export of agricultural commodities, such as Arabica coffee. The Bank of East Java would profit from providing loans to farmer groups. Perhutani is a public company engaged in the protection of forests. Although Perhutani was not directly involved with coffee processing, it became involved because $99 \%$ of the coffee plantations in Bondowoso are farmed in forest areas protected under the management of Perhutani. Perhutani's interest is to ensure that the coffee plantations are managed in accordance with the principles of protected forest management. Following each actor's interests, the roles of the respective actors were clearly stated in the MoU (see Table 4.4).

Table 4.4 The roles of actors in Motramed Bondowoso

\begin{tabular}{|c|c|c|}
\hline No. & Actors & Roles \\
\hline 1. & $\begin{array}{l}\text { District Government of } \\
\text { Bondowoso }\end{array}$ & $\begin{array}{l}\text { Provides facilities and infrastructure and facilitates training and } \\
\text { mentoring. }\end{array}$ \\
\hline 2. & $\begin{array}{l}\text { Bank of Indonesia }(B \mathrm{I}) \\
\text { Jember }\end{array}$ & $\begin{array}{l}\text { - Facilitates technical aid such as research, training and the provi- } \\
\text { sion of information in order to improve farmer competency. } \\
\text { - Facilitates access to financing. }\end{array}$ \\
\hline 3. & ICCRI & $\begin{array}{l}\text { Provides coaching in all stages of coffee production, including } \\
\text { cultivation, processing and marketing. }\end{array}$ \\
\hline 4. & $\begin{array}{l}\text { PT. Regional Development } \\
\text { Bank of East Java (Bank } \\
\text { Jatim) }\end{array}$ & $\begin{array}{l}\text { Provides financing to assist with the development of Arabica coffee } \\
\text { farmers as long as doing so is in accordance with the bank's regula- } \\
\text { tions. }\end{array}$ \\
\hline 5. & "Perhutani" public company & $\begin{array}{l}\text { Provides forest area that could be used to develop Arabica coffee } \\
\text { as long as this is in accordance with principles of sustainable forest } \\
\text { management. }\end{array}$ \\
\hline 6. & PT. Indokom & Is a marketing partner, i.e., buyer. \\
\hline 7. & $\begin{array}{l}\text { Association of Bondowoso } \\
\text { coffee farmers }\end{array}$ & $\begin{array}{l}\text { - Organizes farmers and farmer groups in the area of Bondowoso } \\
\text { - Participates in a program to empower coffee farmers. }\end{array}$ \\
\hline
\end{tabular}

Source: Derived from the Memorandum of Understanding, 21 March 2011.

Based on the MoU and in contrast to the previous regions, the leadership role in Bondowoso was not handled solely by ICCRI; it was shared with the district government and $\mathrm{BI}$ Jember. 
The second difference compared to the other regions is that the quality improvement in Bondowoso showed rapid progress. This progress was made possible by the improved conditions of the old management practice in Bondowoso compared with those in Bajawa. The farmers already had some knowledge regarding post-harvest quality and the market. Unlike previous regions, where it took 1-2 years for the coffee to be exported, it only took approximately 8 months for the five selected farmer groups in Bondowoso to produce coffee with improved quality and export it through PT Indokom. These five farmer groups also had the opportunity to visit ICCRI's coffee plantation in Jember so that they could learn faster. The following was expressed by a member of a farmer cooperative:

After the first harvest period, when our coffee was exported to the Swiss and was recognized by the Mayor, PT Indokom, the Provincial government's representative and other actors, I was full of emotion. Now, I understand the benefits of good processing for the farmer and that the responsibility is in the hands of farmers; the government and other actors can only help farmers improve their production.

For farmers, the collaboration was a great advantage, as they had previously only applied traditional processing (drying in the street without a proper technique) and had only received 7,000 IDR per $\mathrm{kg}$. After they succeeded in improved coffee processing and exporting, the coffee price increased to 22,000 IDR per kg of green beans in 2011. For PT Indokom, this partnership was advantageous, as this region is located near its office headquarters in East Java, which made distribution easier and more efficient.

Despite its rapid progress, we found a few threats at the farmer level that were also discussed at the annual cooperative and coffee stakeholder meetings. First, there was an indication of dishonest behavior by a few farmers regarding profit sharing to Perhutani. According to the cooperation agreement between Perhutani and the forest village community, farmers are required to share $30 \%$ of the coffee production (i.e. red cherries) with Perhutani. However, there were a few unscrupulous individuals who misused the agreement for their personal profit. Second, there were a few farmer groups that did not return the loan to Bank Jatim at the agreed time. The Head of Disbun Bondowoso often reminded farmers of the importance of Bank Jatim's trust in the partnership for the continuation of their coffee business. Third, keeping farmers in the collective commitment was problematic. Coffee farmers in Bondowoso could achieve positive results because they applied the SOP for coffee quality introduced by ICCRI. However, we observed that a few farmers were tempted to obtain more short-term profit by inconsistently following the SOP. Some of the farmers who had participated since the beginning of Motramed became concerned about this condition (as stated in interviews with farmer groups).

These problems might not have occurred if the farmer organizations had sufficiently intervened. In Bondowoso, there are three important farmer organizations; however, 
their roles overlap, and these organizations failed to maintain the farmers' commitment to develop Arabica coffee. This is similar to the situation in Kintamani, Bali. Keeping farmers in a collective is a social problem that is difficult to solve, and it can become one of the constraining factors in the partnership. The following was stated by the senior researcher at ICCRI:

I affirm to farmers that in developing agriculture, the capital problem only plays a small part. If the problems of developing agriculture are $100 \%$, then $60 \%$ of it is a social problem, such as selfishness, internal conflicts, dishonest behavior and more. The technological problem covers approximately $30 \%$ of the problem, and the rest is a capital problem. Farmers always complain about the lack of capital as their main problem, but this is not always the case. If the farmers have good organization and are solid and united, then banks, local governments or other actors will not hesitate to give them aid and financial facilitation.

Although the new production practices are better organized, as shown by the MoU, the issue of farmer commitment needs to be noted. Nevertheless, all actors plan to continue the MoU for the second term and further address the capacity improvement of farmer organizations.

\subsection{Conclusion}

This chapter examined a bottom-up development initiative to create a new partnership for more sustainable coffee production at the local level in Indonesia. We conceptualized the partnering process of the Mediated Partnership Model (Motramed) as a form of collaborative governance to create a new management practice.

Motramed aims to change the practices common in coffee production throughout Indonesia to improve farmers' welfare. Traditional production is characterized by farmers that possess inadequate knowledge regarding quality and price setting. They directly sell their unsorted coffee beans to local traders without further processing. These farmers do not have much capital and face difficulty obtaining funding to develop their coffee farms. Moreover, coffee farmers usually work individually. Although they are sometimes members of farmer groups, these farmer groups are often incapable of assisting farmers. Furthermore, there is no close relationship between farmers, exporters and governments in the old management practice.

The new production methods that Motramed aims to bring about are quite different. The most important changes are that farmers (1) have obtained new knowledge and skills regarding coffee processing, which improves the quality and quantity of their production; (2) have applied collective marketing of coffee in better-organized farmer groups that are part of higher-level regional trading organizations; (3) have direct access to the international market through a permanent relationship with an exporter; (4) are 
sufficiently educated regarding price-setting, have acquired an improved bargaining position and can more easily obtain funding from banks; (5) have become a member in organizations that trade in sustainability certified coffee; and (6) are sustained by local governments that now recognize that coffee production can expand regional economic development and have acquired knowledge to further sustain the farmers.

In this study, we defined four mechanisms: defining a common problem, building trust, creating collaborative advantages and establishing leadership, which we used as a lens to study the changes brought about by Motramed. We analyzed the implementation of the partnerships in three different regions and particularly focused on the constraining and conducive factors that are critical to the success of Motramed. Our main conclusion is that it is particularly difficult for the process of sustainable change to continue after the initial improvement in coffee production. As we have seen, there is a great risk that tensions between individual interests and collective interests will manifest themselves. This indicates that Motramed still creates rather fragile new production practices.

A first critical factor is the scope of the problem. Motramed started with a small and localized problem definition in coffee production, i.e. low quality and inefficient marketing. This restricted definition ensured a practical approach involving only specialized actors to address the problems. Motramed thus primarily focused on the economic aspects of coffee production while the ecological and social aspects were mainly seen as a possible side effect. Only during the partnering process did the relevance of sustainability certification become clear as an important factor in new production practices. It is suggested that a more elaborate model might better balance its focus among the economic, social and environmental aspects of the production process, including the prospect of acquiring certification at the beginning.

A second critical factor is the significant role of district governments. ICCRI would not be able to implement the partnership without the support of local governments in organizing farmers, allocating operational budgets and providing staff. For the local governments, Motramed is a way to promote their regions and improve the regional economy. In the most successful cases, the district government, together with ICCRI's researchers, is continuously and intensively involved in daily practices at the farmer level. The Kintamani and Bondowoso cases in the early years show that a lack of responsiveness from the district governments towards Motramed led to the stagnation of its implementation. Therefore, the implementation of Motramed also depends on the willingness of the district governments to consider coffee production a priority.

A third critical factor is the development of a shared responsibility between the provincial and district governments for the partnership approach. As we have seen, the intention to expand more regions might not be in accordance with the political situation. Since the implementation of regional autonomy in Indonesia, each of the districts has its own priorities, which may differ from higher level government policies. The cases in our study show that the Motramed model works well with the support of the district gov- 
ernments. Nevertheless, regarding budgeting and coordination, it is suggested that the support of provincial governments is essential. Initiators of a partnership model such as Motramed should be aware of the political tensions that they might create in a multilevel governance situation.

A fourth critical factor relates to the organization of the farmers. Among the three regions, Bajawa farmers developed the strongest farmer groups and showed the strongest commitment to keep farmers in collective action. In other regions, the organizations faced the difficulty of convincing farmers that they should abide by the rules of the CGIP organization. After farmers increased their knowledge regarding quality and marketing, the market grew and more buyers became interested, and therefore, farmers had increasing options for selling their coffee. However, this also had a negative side, as some farmers tended to show opportunistic behavior and focused on their own short-term economic profits. These farmers preferred to sell in smaller quantities to many buyers rather than to only to one exporter under the CGIP organization. This may result in a decline of trust between farmers and exporters. Therefore, strengthening the capacity of farmer organizations and raising awareness regarding the virtues of collective action is an essential asset of the partnership model.

A fifth critical factor is regarding the question of how many and what type of actors to involve in the partnership. Inducting more actors may result in additional risks because of different interests and perceived problems. In the third region, we observed that Motramed involved more actors from various backgrounds as partners. The positive side of this is that with additional actors and different resources, more aspects of the coffee sector can be addressed, which might hasten progress. If there are additional participating actors, then there are additional interests that require consideration and these interests may be competing or conflicting. However, our research shows that the participation of actors who are able to secure funding, such as banks, positively influences the results of Motramed.

Recently, ICCRI has started to expand the Motramed model to many regions in Indonesia. Together with local governments, Motramed has been initiated not only for Arabica coffee but also for Robusta coffee and cocoa. Discussion is also continuing regarding the adoption of the Motramed model in a national program of the Ministry of Agriculture. This will create additional opportunities to develop a nationwide bottom-up development process to improve smallholder production of agricultural commodities, but it may also lead to bureaucratization of the approach with much red tape. Further research on the conditions of an effective national program should be the next step in advancing this type of bottom-up sustainable development of the smallholder coffee sector with a connection to global certification schemes. 


\section{Chapter}

Public agricultural extension workers as

boundary workers: Identifying sustainability perspectives in agriculture using Q-methodology 


\section{Abstract}

This chapter examines the role of public extension workers as boundary workers in Indonesia. We conceptualize good boundary work as the ability to develop a similar perspective on sustainable agriculture by extension workers and their respective farmers. A similar perspective implies that extension workers have fulfilled their function as boundary worker in translating the abstract concept of sustainability into salient knowledge for farmers. We used Q-methodology to analyze perspectives on sustainability, which resulted in two perspectives; the technologist and the environmentalist. The technologists perceive sustainable agriculture as the use of organic pesticides, and they strongly agree that the responsibility for sustainable agriculture belongs to extension workers. The environmentalists value the environmental aspects of sustainable agriculture. The chapter describes three case studies that differ in the quality of their extension work. Good boundary work needs some prerequisites; highly motivated extension workers; the ability to gain trust from farmers; willingness of farmers to adopt new knowledge from extension workers; and government support for extension.

Submitted to the Journal of Agricultural Education and Extension as:

Wijaya, A., \& Offermans, A. Public agricultural extension workers as boundary workers: Identifying sustainability perspectives in agriculture using Q-methodology 


\subsection{Introduction}

It is widely acknowledged that access to knowledge, information and education contribute positively to farmer's livelihoods and a country's agricultural production (Haug, 1999; Hunt et al., 2014). It increases yields, allows farmers to better deal with market issues (Rivera, 2011), and enhances farmer's human capital and a safer use of chemicals (Baig \& Aldosari, 2013; Feder, Murgai, \& Quizon, 2004). Knowledge and information may also be powerful tools in the process of agricultural change (Haug, 1999), for example, towards a more sustainable agricultural production system (Rivera, 2011). Information exchange aimed at farmers is often referred to as extension. In this chapter, we follow a definition by Birner et al. (2009, p. 342) stating that extension "[..] support[s] and facilitate[s] people engaged in agricultural production [in particular smallholder farmers] to solve problems and to obtain information, skills and technologies to improve their livelihood and wellbeing."

The transfer of research-based knowledge to farmers is, however, a challenging task. First, because relevant farmers significantly outnumber available experts, which involves the need to duplicate knowledge and make it available to a larger audience (Mundy, 1992). Second, because farmers are scattered geographically, while researchers are generally located in one region. Third, because research-based knowledge, which can be considered rather abstract, must be made understandable for the farmers and be adapted to the local situation (Mundy, 1992). Fourth, because extension workers are no longer considered the exclusive holders of knowledge, and farmers no longer the passive recipients of knowledge or technology (Faure, Desjeux, \& Gasselin, 2012; Haug, 1999). This trend goes together with a shift from spreading research-based knowledge to farmers towards assisting farmers to express and achieve their interests (Rivera, 2011), the so-called participatory approach towards extension. As a result, actors involved in agricultural extension change from being subject specialists towards mediators between involved parties (Faure et al., 2012; Mangnus \& Bitzer, 2015). A fifth factor contributing to the daunting task of knowledge transfer regards a decrease in governmental support for extension (Benson \& Jafry, 2013; Faure et al., 2012; Haug, 1999; Hunt et al., 2014; Lauzon, 2013; Rivera, 2011). Although governments may remain involved in the extension system in a different manifestation, like subsidizer, regulator or coordinator (Haug, 1999; Rivera, 2011) or broker (Garforth et al., 2003). With a withdrawing government, there is a trend towards greater privatization and decentralization of extension services. The former also implies that extension services are increasingly used by private firms to promote their commercial activities (Faure et al., 2012). In addition, there are fewer opportunities for public extension workers to improve their capacity and renew knowledge, which influences the quality of public extension negatively (Bitzer, 2016; Marliati et al., 2008). Finally, we see that consumer demands for more sustainable products influenced the debate on how agricultural practices need to be changed to become more sustainable. Abstract and Northern-based perspectives of sustainability are, 
however, difficult to align with expectations and realities of farmers in the field. This offers further challenges for extension workers to translate and apply abstract notions of sustainability to practices at the producer level.

Following the aim to provide farmers with access to salient knowledge on sustainability, there is a need for knowledge facilitators or -brokers who can deal with the abovedescribed challenges. In this chapter, we will focus on the role of Indonesian public extension workers as knowledge brokers (boundary workers) for linking knowledge on sustainable agriculture to practice at the producer level. We conceptualize good boundary work as the capacity to convey one's knowledge on, and perspective of, a concept to a third party in such a way that the third party develops a common understanding of the topic at stake. More concretely, and adapted to extension work in Indonesia, we conceptualize good boundary work as the existence of similar perspectives of sustainable agriculture between public extension workers and farmers.

The central research question that we will answer is: To what extent do Indonesian public extension workers fulfill the function of boundary worker in the case of sustainable agriculture? First, we elaborate on extension in the Indonesian context before we introduce our analytical framework and research methods. In the results section, we will compare farmers' and extension workers' perspectives of sustainable agriculture and answer our research question. The last section will be devoted to the conclusions.

\subsection{Extension in the Indonesian context}

Indonesia has a long history in agricultural extension and can be considered a frontrunner in the development and application of farmer field schools. Improving the agricultural production (i.e., through efficiency gains) has long been an important goal within extension activities in Indonesia. Overall, agricultural production in Indonesia increased in the period between 1960 and 1992, but decreased afterward and even became low compared to other countries and historical records in Indonesia. Several aspects explain this trend, but a decline in agricultural extension services and a decline in the number of farmers reached by agricultural extension are frequently mentioned among them (World Bank, 2007). The decentralization policies set in motion by the Suharto regime in 1998 further influenced the context of extension in Indonesia. Reductions in funding, removal of central-level guidance, and substantial changes in the structure of extension led to more uncertainties but also contributed to a more bottom-up participatory approach towards extension that is said to better suit the needs and demands of farmers in a specific region (World Bank, 2007). Independent from decentralization, Indonesian extension has undergone substantial and frequent changes in the last five-to-six decades (see World Bank, 2007 for an overview), leading to doubts and uncertainties among farmers, 
and a situation in which local governments ignored new responsibilities regarding an extension ${ }^{18}$. With regards to sustainability, the 16/2006 law on an extension for agriculture, fisheries, and forestry can be considered relevant as it aims to promote economically feasible, environmentally sustainable and socially acceptable farming practices and to increase productivity, efficiency, and farmer's income through extension. It explicitly refers to the government's obligation to arrange education in the sectors of agriculture, fisheries, and forestry, but also recognizes the involvement of private actors in the extension system, and supports a multi-provider system with increased coordination between the central, provincial and district levels. With this new law, the focus of extension activities moved from a commodity-based system towards a district-based system (Undang Undang 16, 2006; World Bank, 2007). These changes imply that public extension workers in Indonesia need to perform their tasks under the circumstances they are not used to it. This includes the fact that they have to shift their attention from one specific commodity to a diversity of commodities.

\subsection{Analytical framework}

In this chapter, we conceptualize agricultural extension services as boundary work. Knowledge and information on sustainability cannot directly evolve from knowledge producers to knowledge users as it requires the articulation of the concept into a language and practices that are understandable for farmers and applicable to their daily practices. Boundary workers may mediate between the domains of knowledge supply and knowledge use (practices) and may provide clarity to farmers on the meaning of the concept of sustainable agriculture and ways in which it can be applied to practice.

Based on literature, we identify six key characteristics of boundary work in agricultural extension:

1. Boundary work takes place at the intersection of the knowledge providing domain (i.e., experts, researchers, formal training programs for extension workers) and the knowledge receiving domain (i.e., farmers who are supposed to internalize this knowledge into their daily practices) (Clark et al., 2011; Kristjanson et al., 2009).

2. It aims to facilitate collaboration and understanding between the knowledgeproviding and knowledge-receiving domain with the aim to create results that are relevant for both domains (i.e., a more sustainable agricultural production) (Boezeman, Vink, \& Leroy, 2013; Tisenkopfs et al., 2015).

\footnotetext{
${ }^{18}$ Which was the case for Decree number 130-67/2002 explaining the functions of local governments in extension (World Bank, 2007).
} 
3. Boundary work thus requires processes of translation, coordination, and alignment of knowledge and expectations from actors in different domains (Cash et al., 2003; Wenger, 1998). It also demands a selection and integration of knowledge inputs from various actors and managing the production of knowledge (Offermans \& Glasbergen, 2015; Tisenkopfs et al., 2015).

4. Therefore, boundary work can be considered a process that needs to be facilitated and managed by a boundary worker (i.e., extension worker). Boundary workers have to manage their position carefully and need to gain legitimacy and credibility in both domains (Cash, 2001; McMillan, 2011).

5. It is not easy to facilitate and manage boundary work as it is filled with tensions, conflicting interests and contradictory impulses (including perspectives) from actors in the different domains (Clark et al., 2011).

6. Boundary workers do not represent individuals, but part of institutions. This implies that they do not only have to find their position in the knowledge providing and knowledge receiving domain, but also in their professional role, including rules and practices (McMillan, 2011).

Boundary work for sustainable agriculture requires well-functioning boundary workers. Besides challenges inherent to boundary work, extension workers are also confronted with more general challenges related to the practice of extension. These challenges include the provision of a low income for extension workers, poor incentives and facilities to provide meaningful extension to farmers, a lack of opportunities for further education and skills development (World Bank, 2007), and the fact that it is not an easy task for extension workers to facilitate farmer-based learning in an adult education perspective (Elsey \& Sirichoti, 2002). Further, more challenges may be identified that specifically apply to extension in the Indonesian context, such as the geographical focus (instead of crop focus), the fact that many farmers live in remote areas that are difficult to access, the confrontation with unclear responsibilities that lead to uncertainty regarding expectations and authority, and low levels of financial and organizational governmental support. Indonesian public extension workers have to navigate in a landscape interwoven with challenges, which we conceptualize in the following analytical framework: 


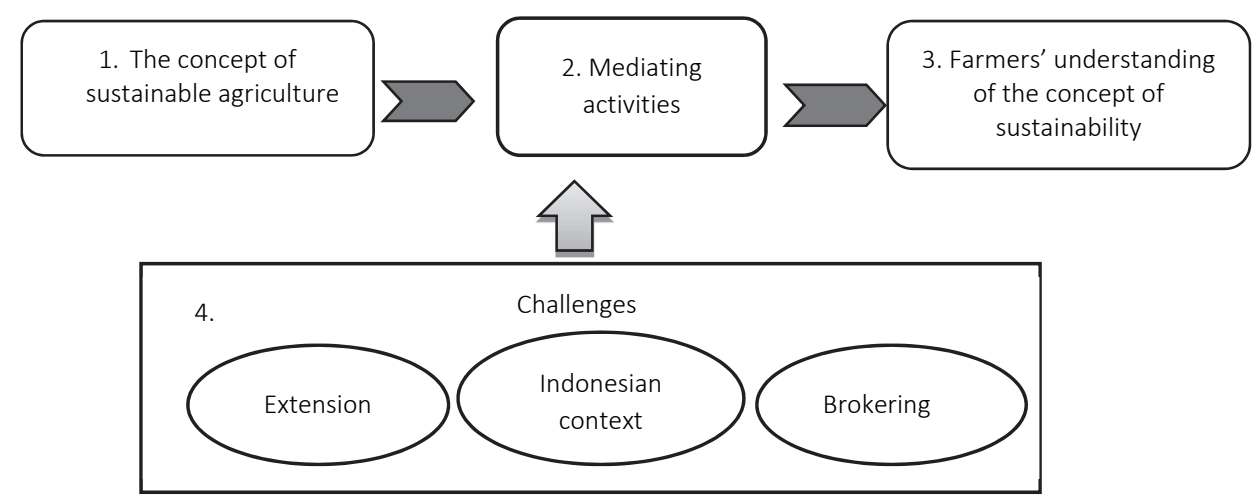

Figure 5.1 Analytical framework

We consider extension workers to perform well if their perspective of sustainability is similar to farmers' perspective of sustainability (i.e., if the extension workers' perspective in box 1 in Figure 5.1 is equal to the perspective in box 3). If farmers and extension workers have different perspectives on sustainability, then the knowledge transfer, and with it, the boundary work, may not function flawlessly.

\subsection{Method: Q-methodology}

Crucial in our approach is a comparison between farmers' perspective of sustainable agriculture and extension workers' perspective of the same concept. Different approaches towards measuring perspectives exist, including the use of pre-defined typologies informed by theory (for example, Cultural Theory) and more open-ended typologies such as Q-methodology. The latter is an innovative way to study human subjectivity from a qualitative approach in combination with a statistical, quantitative approach (Barry \& Proops, 1999; Ellis, Barry, \& Robinson, 2007; Watts \& Stenner, 2005). It was developed by the psychologist William Stephenson in 1935 and has been widely used in psychology, but also in political science, sociology, and health sciences. Q-methodology is gaining popularity in the sustainability domain and agricultural research. Examples of applications in these domains include research on sustainability and environmental discourses (Barry \& Proops, 1999; Curry, Barry, \& McClenaghan, 2013); organic farming (Mandolesi et al., 2015); and rural innovation and research (Hermans et al., 2012; Previte, Pini, \& Haslam-McKenzie, 2007). Q-Methodology allows obtaining individual perspectives on sustainability and environmental issues and analyzing differences and similarities in perspectives on these matters. It heavily relies on the identification of statements. These statements, however, are not pre-defined but obtained from interactions between researchers and respondents through interviews and from a literature 
analysis, which allows selecting, and in addition to that covering, a variety of perspectives on the topic at stake (Barry \& Proops, 1999).

\section{Procedure and sampling}

Q-methodology consists of six stages: generating the concourse, formulating a Q-set, selecting respondents, Q-sorting, analyzing Q-factors, and perspective of the results (Barry \& Proops, 1999; Cuppen, 2010; Hermans et al., 2012; Mandolesi et al., 2015).

The first stage (generating the concourse) refers to the collection of statements covering all possible prevailing views on a certain topic (Hermans et.al., 2011; Mandolesi et.al., 2015), sustainable agriculture in the case of this chapter. Wright (2013) explains that generating the concourse should be conducted under scrutiny and avoid repetitive and confusing statements. For this chapter, we collected statements through semistructured interviews with officials in the Ministry of Agriculture, the head of the Indonesian association of agricultural extension, a self-help extension worker (exemplary farmer), an exemplary public extension worker, researchers from the Agricultural Institute in Bogor, and representatives from a development organization engaged with poverty alleviation and sustainable development (UNCAPSA). The interviews took place from October to November 2016. In addition to the interviews, we collected statements about sustainable agriculture from published academic chapters in global and Southeast Asian perspectives (i.e., Indonesia). Combining these primary and secondary data, we identified 200 statements about sustainable agriculture that applicable in Indonesia.

The second stage comprises the formulation of a so-called Q-set. A concourse of 200 statements is namely too large to be handled by respondents. To be manageable by respondents, we reduced the statements by combining and grouping them into more general themes and topics (Wright, 2013). We followed a so-called unstructured, naturalistic approach to formulate our Q-set through identifying five general themes on sustainable agriculture. These five themes include definitions, economic aspects, environmental aspects, social aspects, and statements on responsible actors for sustainable agriculture. Then, we assigned the statements to one of the five themes. The number of statements in each theme varies between 5 to 11 statements in each topic (see Table 5.1).

Table 5.1 The unstructured sampling matrix with the five themes and the number of statements in each theme

\begin{tabular}{lcc}
\hline & Topic & Amount of statements \\
\hline General definition & 5 \\
Economic aspect & 8 \\
Environmental aspect & 11 \\
Social aspects & 6 \\
Responsible actors & 7 \\
\hline Total & 37 \\
\hline
\end{tabular}


These 37 statements are sufficient in representing the themes and can be handled by the respondents. All 37 statements were translated to Bahasa Indonesia (first by the researcher and later by the researchers' colleagues to verify the translation), then printed on small cards and numbered. To test the comprehension of the statements, we tested this $Q$ sample with the exemplary extension worker who participated in the interview sessions.

The third stage comprises the selection of respondents. One characteristic of Qmethodology is that it does not need a large sample as required in surveys and questionnaires. The important point in selecting respondents is considering the breadth and diversity of the perspectives represented in the sample (Hermans et al., 2012; Mandolesi et al., 2015). Our target groups are public extension workers and their assisted farmers $^{19}$. Since the number of respondents is, regarding the reliability of the results, less important than the representativeness, we tried to include farmers and extension workers with various backgrounds. Regarding extension workers, we consciously included public extension workers with less than ten years and more than ten years working experience. Meanwhile, for farmers, we distinguished between advanced farmers or certified farmers (i.e., who received additional training on sustainability issues) and nonadvanced or traditional farmers (i.e., who rarely or never receive additional training). We conducted this research in three districts in Indonesia (see Table 5.2): North Luwu (South Sulawesi), Bondowoso (East Java), and Pelalawan (Riau) as representatives of the three largest islands in Indonesia. These locations cover different agricultural commodities: palm oil, cocoa, coffee, and rice.

Table 5.2 Respondents from three districts

\begin{tabular}{lcccc}
\hline Respondents groups & $\begin{array}{c}\text { North Luwu } \\
\text { (District 1) }\end{array}$ & $\begin{array}{c}\text { Bondowoso } \\
\text { (District 2) }\end{array}$ & $\begin{array}{c}\text { Pelalawan } \\
\text { (District 3) }\end{array}$ & Total \\
\hline $\begin{array}{l}\text { Public extension workers } \\
\text { - Less than 10 years working experience }\end{array}$ & 6 & 10 & 6 & 22 \\
- More than 10 years working experience & 6 & 2 & 1 & 9 \\
Farmers & 4 & 8 & 1 & 13 \\
- Advanced/certified & 9 & 5 & 6 & 20 \\
- Non advanced/traditional & Cocoa and & Rice and & Horticulture \\
- Crops & rice & coffee & and Palm oil \\
\hline Total & 25 & 25 & 14 & 64 \\
\hline
\end{tabular}

North Luwu in South Sulawesi is well known as the largest cocoa production area in Indonesia, and part of the plantations in North Luwu are already certified by Rainforest Alliance private certification scheme. Moreover, many NGOs and other international

\footnotetext{
${ }^{19}$ To guarantee this, we selected extension workers and farmers from the same sub districts. In most cases we could guarantee the involvement of extension workers and the farmers they actually teach (allowing us to compare their loadings 1-by-1). For an overview, see appendix B.
} 
organizations locate their (development) projects in this district. Bondowoso in East Java represents Java Island which is well known for its rice and Arabica coffee production. The last district is Pelalawan in Riau. This district was chosen because of the presence of private (RSPO) and public (ISPO) palm oil certification.

\section{Data collection}

The fourth stage includes the sorting (i.e., ranking) of the statements by respondents. A total of 64 respondents were asked to rank the 37 cards, each containing one statement on sustainable agriculture. Respondents were asked to rank each statement along with a normally distributed, pyramid-shaped grid. This grid covered a nine-point scale varying from strongly disagree (-4) to neutral (0) and strongly agree (+4) (Curry et al., 2013; Mandolesi et al., 2015). In the pilot phase (i.e., in which we tested this procedure) we found that our respondents experienced difficulties in expressing disagreement to any of the statements. We reasoned that this results from Indonesian culture in which it can be considered impolite to express disagreement. We solved this by rephrasing our task towards the respondents: instead of ranking the statements from disagreement towards agreement, we asked them to rank the statements based on least agreement (-4) towards very strong agreement (+4) (see Figure 5.2).

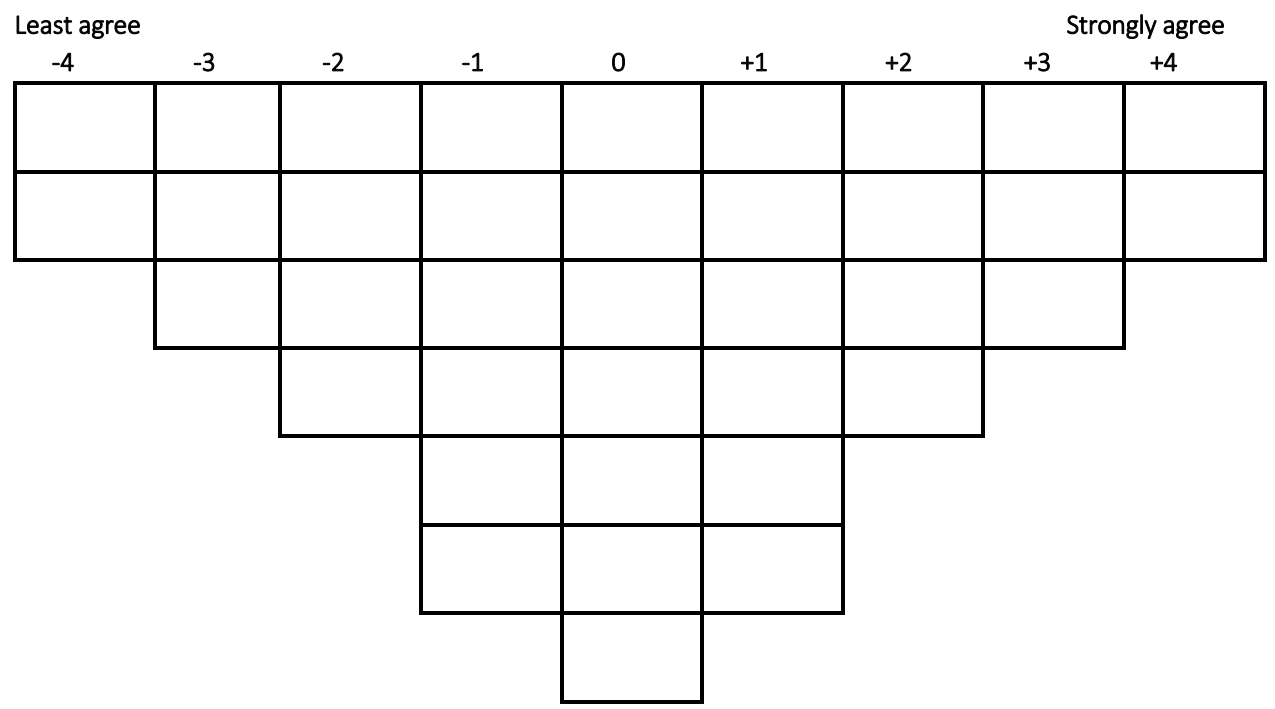

Figure 5.2 Q-grid

Before and after the Q-sorting, respondents were interviewed to explain their reasoning behind the choices made in the ranking to better understand their perspectives of sustainable agriculture. We explicitly asked whether the respondents missed a statement in the Q-sort on sustainable agriculture, which occasionally happened (an example 
includes a statement about agricultural technology and the danger of pesticides). However, we consider that these statements have already been covered with statements in the Q-set. A topic on the danger of pesticides is for example covere in statement 22 (pest management through the use of pesticides is unsustainable).

In addition to $Q$ methodology, we organized focus group discussions (FGDs) and did interviews. FGDs with extension workers were conducted in all three districts. These FGDs aimed to discuss extension workers' experiences in translating knowledge to farmers. We also conducted in-depth interview with extension workers (i.e. those who did not participate in FGDs) and farmers in three districts. The topics of the interviews related to how extension workers shape and arrange their extension activities, and the type of challenges they are confronted with regarding boundary work. The farmers were enquired on their view on the performance of extension workers. The data collection took place from November 2016 to January 2017.

\section{Analysis and perspective}

The fifth stage of Q-methodology comprises the analysis of the Q-sort, with the use of PQMethod software (Schmolck, 2002). This software was expected to analyze the data effectively and comes in a free package (Watts \& Stenner, 2005). Firstly, we transferred the results into a so-called $\mathrm{Q}$-sheet in the original bipolar scale $(-4$ to +4$)$. Then, the data were factor-analyzed to identify patterns among individuals within groups (see Previte et al., 2007 for more information). The ultimate idea is to identify several factors explaining variation in perspectives on sustainable agriculture. There are two ways to extract (unrotated) factors: centroid analysis and principal component analysis (Schmolck, 2001). In this chapter, we used the principal component analysis (PCA) with varimax (automatic) rotation, as this procedure is considered to be reliable and relatively univocal in its perspective (Wright, 2013). All 64 Q-sorts (i.e. each equaling one perspective of one respondent) were entered into the program, analyzed and distributed along eight unrotated factors. Then, we selected two factors with the largest difference in their so-called eigenvalues $^{20}$ for the varimax rotation. The basic requirement for the selection of factors is an eigenvalue of more than 1.00 (Wright, 2013, p. 81). As all eight factors meet this requirement, we selected the two factors with the largest differences in eigenvalues, i.e., 15.5564 and 5.5923. The rotation assures to find as much variation in the factors as possible. We did not distinguish between groups (extension workers and farmers) in the analysis but analyzed all Q-sorts at once to make it easier to compare between the perspectives of the extension workers and their respective farmers.

\footnotetext{
${ }^{20}$ Eigenvalue (characteristic value) is the sum of squared factor loadings for that factor (Watts \& Stenner, 2005, p. 87).
} 
The last stage comprises the perspective of the result of the factor analysis. The statistical analysis resulted in two factors (factor A and B, see table 5.3). Respondents with a similar perspective on sustainable agriculture are distributed in the same factor, and results inform us on the degree of agreement and disagreement between the factors for each statement (Curry et al., 2013).

\subsection{General perspectives of sustainable agriculture}

Although respondents in factor A and B differ in their perspective of sustainability, they also have perspectives in common. The overall, and relatively agreed-upon, perspective on sustainable agriculture perceives the use of organic pesticides as sustainable. It also implies that (grand)children have the opportunity to still experience the farms' benefits. Respondents in general strongly reject the statements that modern agriculture, mass production and industrial approaches towards agriculture would be unsustainable. They also reject that farmers who financially struggle to survive cannot act sustainably. 


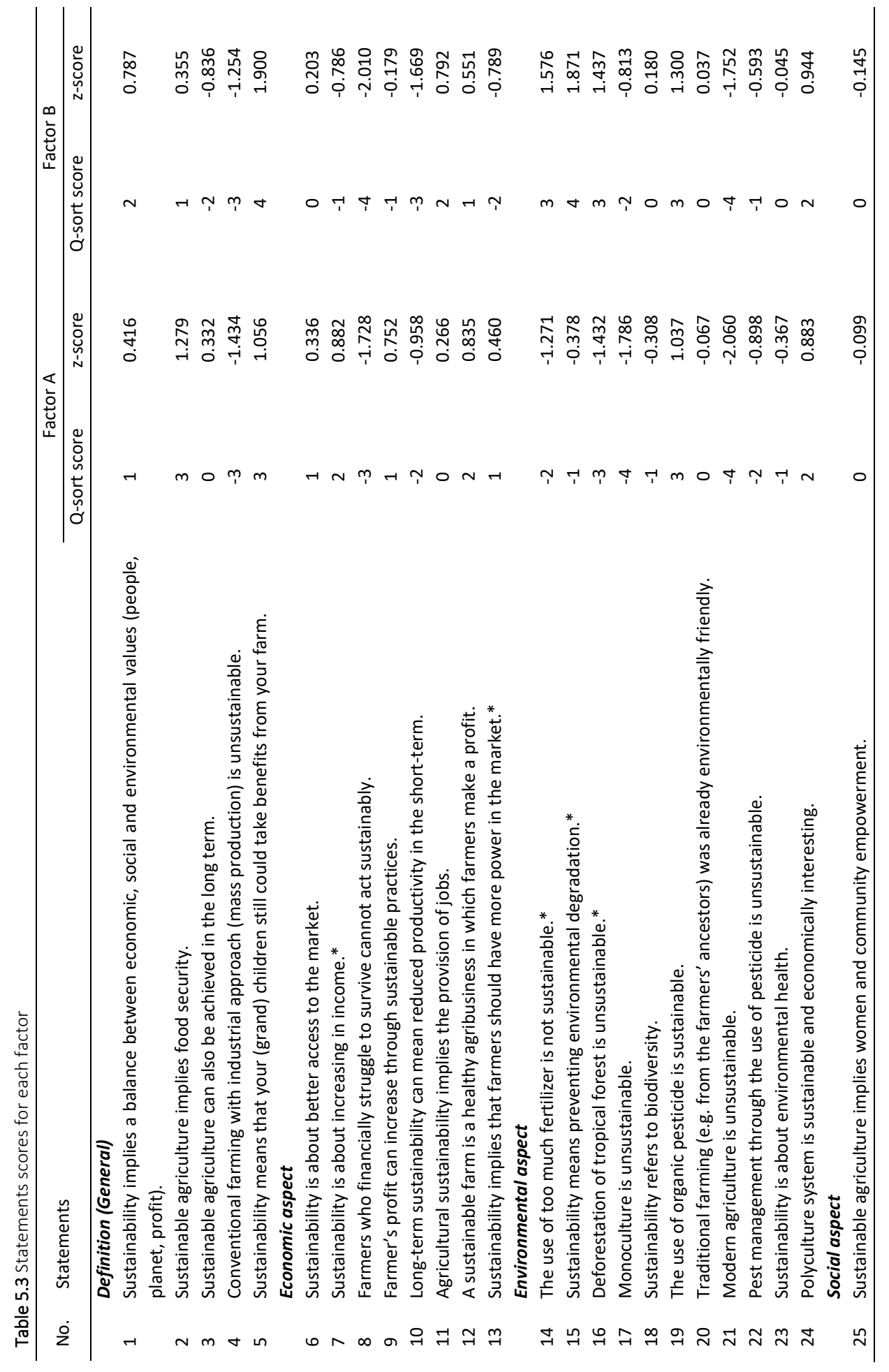




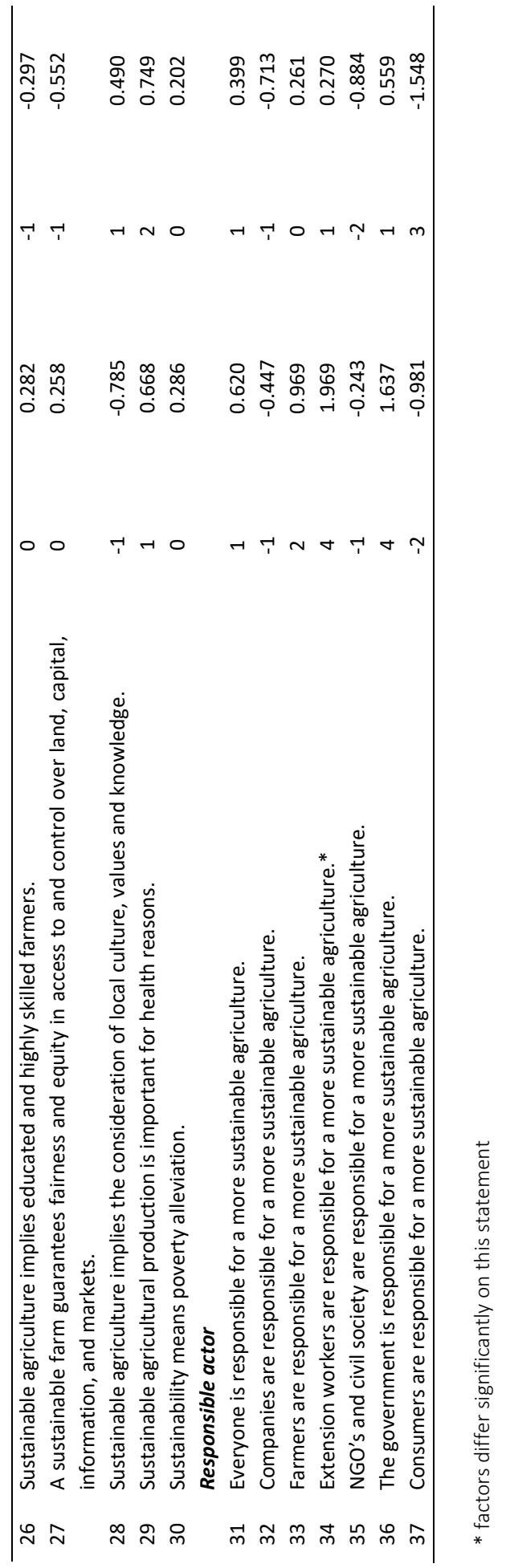


Both factors significantly differ in their perspective of 6 statements (see statements in table 3 with *). Three of these statements belong to the environmental theme: respondents in factor B strongly agree that the use of too much fertilizer and deforestation of tropical forest can both be considered unsustainable. Respondents in factor $A$, on the contrary, did not evaluate these issues to be unsustainable. Next, respondents in factor B strongly agree that sustainability means the prevention of environmental degradation, while factor A slightly disagrees with it.

Two more distinguishing statements relate to the economic theme. Respondents in factor A understand the concept of sustainable agriculture as a practice to increase farmers' income, and to provide farmers with more bargaining power in the market. On the contrary, respondents in factor B disagreed with both statements, which implies that respondents in factor $B$ do not believe that sustainability and more income can develop in parallel or that sustainability may improve farmers' bargaining power in the market. Regarding the theme of responsibility for sustainability we found that respondents in Factor A perceive extension workers as important actors to create a more sustainable agriculture, while respondents in factor $B$ agree to a much lesser extent.

\subsection{Factor A: Technologist}

The total number of respondents in factor A equals 36 (out of 64) consisting of 13 extension workers and 23 farmers from all three districts. The majority of farmers are part of this factor. Respondents in this factor largely perceive sustainable agriculture as food security and the use of organic pesticides. Further, they firmly believe that sustainable agriculture belongs to the responsibility of extension workers and also the government, and emphasize that monoculture and modern agriculture can be largely sustainable; technological and industrial approaches are not considered to be unsustainable. Deforestation is also not necessarily seen as unsustainable, and although they believe that long-term sustainability may hamper the productivity of the farm, they reject the statement that farmers who financially struggle to survive cannot be sustainable. Social aspects are the least important once according to this factor (i.e., scoring around 0). 


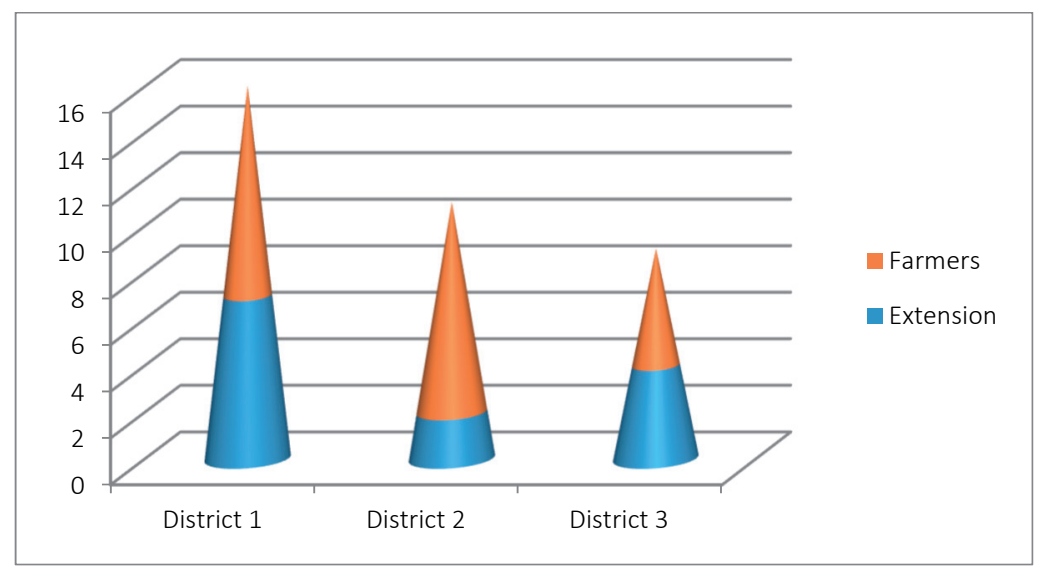

Figure 5.3 The loading of respondents in factor $A$ in the different districts

The figure above shows the distribution of respondents in factor $A$ in each district. In district 1 and 3 , the number of farmers and extension workers is quite balanced ( 9 versus 7 in district 1 and 5 versus 4 in district 3), which implies that both groups share a rather similar perspective on sustainable agriculture. In district 2, however, the majority of farmers, and only 2 extension workers, loads in this factor. From all farmers in this factor, the majority grows rice (14 out of 23) and all organic rice farmers in district 2, who are part of this study, load in factor $A$.

\subsection{Factor B: Environmentalist}

Factor B consists of 28 (out of 64) respondents, including 18 extension workers and 10 farmers in all three districts. Respondents in factor $B$ believe that deforestation and the use of too much fertilizer is unsustainable, and that the concept of sustainability implies the prevention of environmental degradation. Factor B shows a rather strong agreement on statements in the environmental theme, followed by economic and social aspects. Further, respondents in factor B do not consider specific actors to be responsible for sustainable agriculture; instead they believe that everybody should take responsibility for sustainability regardless of their title or position. 


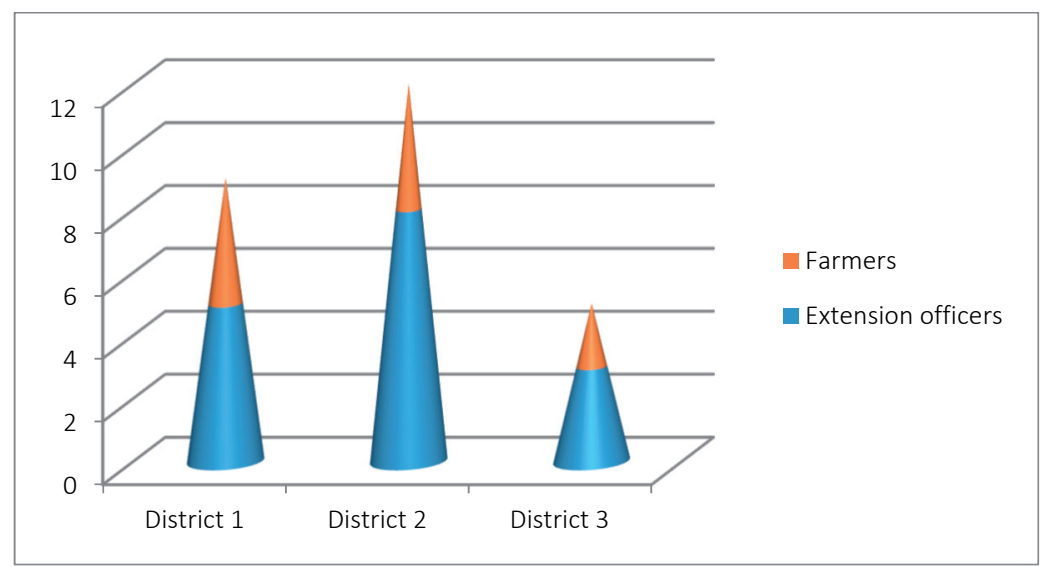

Figure 5.4 The loading of respondents in factor B in the different districts

The figure above shows the distribution of respondents in Factor B in each district. Overall, extension workers are more dominantly represented in this factor $(n=18)$ compared to farmers $(n=10)$. Here again, we see a rather equal distribution of extension officers and farmers in district 1 and 3 , and an unequal distribution in district 2 (9 extension workers and 4 farmers). Most extension workers in this factor are relatievely young and have less than 10 years of working experience.

\subsection{Boundary work}

The results identify two dominant perspectives on sustainable agriculture. Both factors include extension workers and farmers, and share some commonalities. This can be considered positive from a boundary work point of view. However, we also identified differences between the factors, and extension workers and farmers in one region are not always loaded in the same factor. This may imply differences in perspectives on sustainable agriculture between extension workers and their respective farmers, which indicating poor performing boundary work.

In the interviews and FGDs we learned that extension workers have to put quite some efforts in finding credible sources of knowledge regarding sustainability and have to proactively search for possibilities to translate this knowledge to the farmers. Extension workers' understanding of the concept of sustainable agriculture comes from various sources such as training provided by the government and private parties, literature, flyers or guidebooks from higher level governmental agencies, and from higher formal education. Extension workers, mostly the younger generation, also explore information from the internet which they currently consider more reliable than the infrequent training courses from the government. Extension workers in all districts acknowledged that they face barriers in the process of translating knowledge on sustainable agriculture to 
farmers, including language barriers, farmers' attitude (and resistance to change) and a lack of support from local governments (resulting in limited financial sources and time to fulfill the role of boundary worker).

\section{District 1: North Luwu, South Sulawesi}

In this district, we see a rather balanced distribution of extension workers and farmers over the two factors (see Figure 5.5). In at least $85 \%$ of all cases, we found a match between the extension workers' perspective on sustainable agriculture and the perspectives of the farmers taught by them (see Appendix C). Based on this, we conclude that extension workers in North Luwu perform rather well regarding boundary work, which has a few reasons.

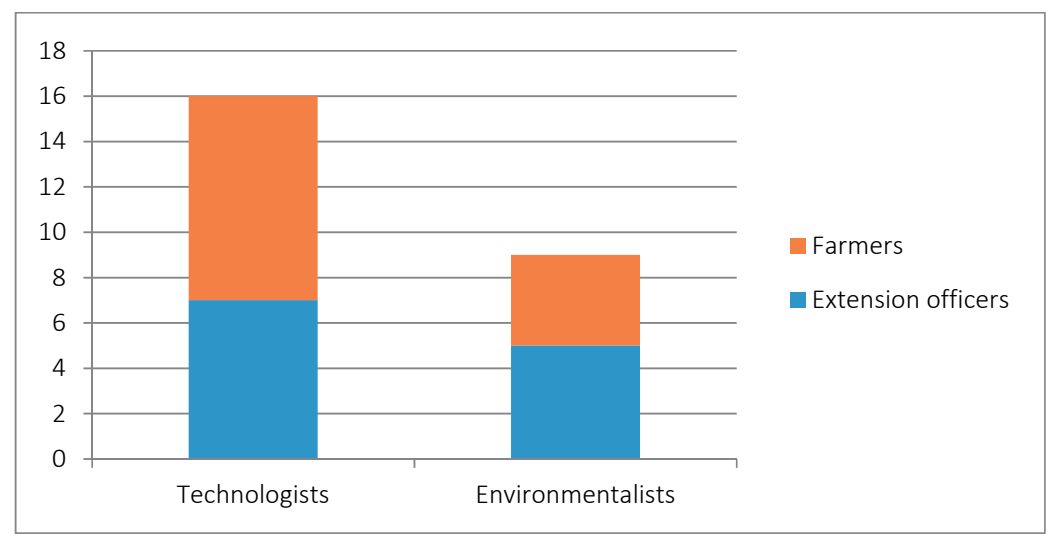

Figure 5.5 The loading of two factors in North Luwu

The first reason is that the extension workers in North Luwu can be considered very motivated. This means that the extension workers are eager to spend time on conveying information to the farmers and adapt knowledge to the (crop specific) demands and capacities of the farmers. Second, we see that extension workers in North Luwu have connected to the farmers on a personal level. Farmers and extension workers know each other very well, and strong social relations exist. As stated by one of the extension workers in this district, building strong relations with farmers can be considered a crucial step in fulfilling the role of boundary worker rightfully,

[...] we convey the information from above (governmental policies or other sources) through customizing this information to the educational background of the farmers. We use daily and practical language that is easy to understand by the farmers. This area is a transmigration area with farmers originating mostly from Java and Bali. This implies that extension workers have to learn the farmers' original, local languages to 
communicate in a meaningful way with them. It is also possible to ask village officials to help us in translating information and knowledge into local languages.

A third reason behind the successful boundary work, is that this district is an important cocoa producing region where many development projects have been implemented, and where the farmers receive training (including information on sustainability) on a regular basis. The training is often provided by private cocoa companies and NGOs, and attended by public extension workers. Although food crops, i.e., rice are the main priority for extension workers in Indonesia, the motivated extension workers in North Luwu also turned out to be knowledgeable on cocoa sustainability, which is unlikely to be the case in other districts. Moreover, development projects often already cooperated with the district government of North Luwu to improve cocoa farmers' livelihoods and the sustainability of their production. Training from private actors makes farmers more open-minded to adapt "new" knowledge and sustainability practices, as the source of information is not limited to only extension workers, but also NGOs and companies. In this district, we can therefore say that the presence of private extension in the form of development projects smoothens the boundary work of extension workers in the sense that farmers already heard about sustainability before and because development projects have employed economic incentives to persuade farmers to participate in sustainable farming which was well received by the farmers.

The fourth reason regards the support from the district government for the agriculture sector and extension. We saw that the district government provided local budgets (APBD) to extension workers as a monthly allowance and provided them with a motorcycle for operational needs. As mentioned by some extension workers, their allowance is higher than the allowance of extension workers in other districts around North Luwu. These supports further increase the extension workers' motivation and they feel responsible for working harder in assisting farmers. The district government of North Luwu, including its mayor and legislative assembly, further supports the extension agency as an independent agency in this district. As stated by the coordinator of extension workers in one sub-district in North Luwu:

In the last two months, we (extension workers) were worried about our fate because the district government planned to restructure the nomenclature of governmental organizations in line with law 23/2014 and government decree $18 / 2016$. This change affects the position of extension agencies ${ }^{21}$. However, we are

\footnotetext{
${ }^{21}$ In the last decade, the Indonesian government issued regulations related to agriculture and extension. Law $23 / 2006$ on extension for agriculture fisheries, and forestry is giving certainty on the status of extension workers as a profession and functional position in governmental organizations. However, there is no uniformity yet on the law implementation at the local level, where some regions established an Extension Agency, but other regions still incorporated extension with the Agency of Agriculture or Agency of Food Security. In addition to
} 
relieved that our (district) government, including legislative and executive boards, agreed that extension remains an independent agency and even plans to improve its status from Board into Agency, i.e., Agency of food security and extension. We heard that in other districts, the status of extension agencies is much worse.

\section{District 2: Bondowoso, East Java}

In Bondowoso, in $47 \%$ of the cases (see appendix C) the perspective of the extension worker did not match with the perspective of his farmer. Based on this we conclude that extension workers in Bondowoso do not successfully fulfill their role as boundary workers (see Figure 5.6). Although there is no local language barrier in this region as the farmers in this region are homogeneous and originating from Java, there are some conditions that may explain why boundary work in this region is not successful.

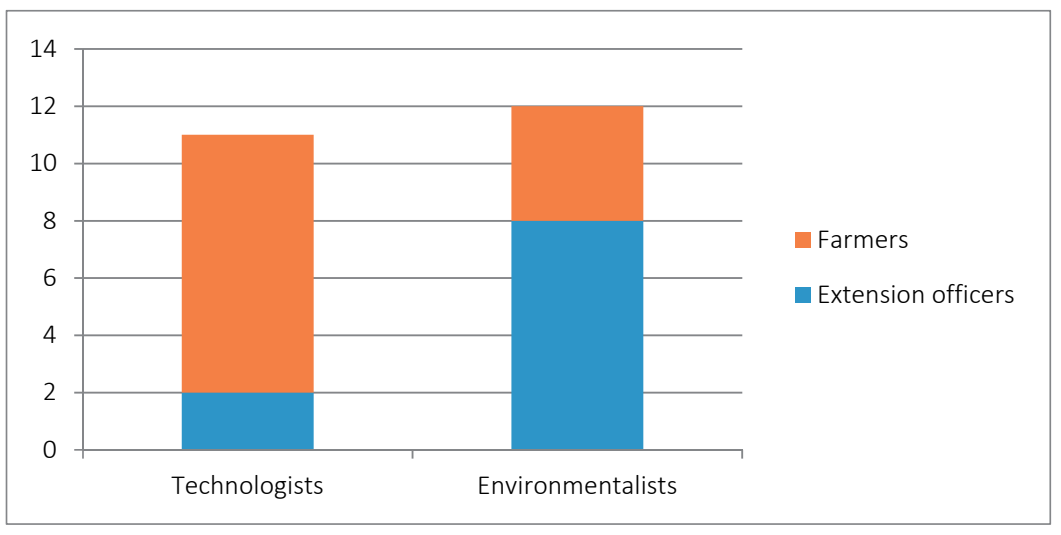

Figure 5.6 The loading of respondents in the two factors in Bondowoso

Different from district 1 , the extension workers in district 2 do not seem emotionally connected to the farmers; strong social relationships between farmers and extension workers seem an exception rather than a rule. This leads to difficulties on behalf of the extension workers to convince farmers to change their attitudes and practices and to overcome differences in perspective on sustainable agriculture.

that, the Law 23/2014 on local government and Government regulation (PP) 18/2016 on regional instruments (Perangkat Daerah) implied a restructuring of organizational local governments and budget allocations. The ways in which these restructuring actions shape, depend on the priorities set by local governments. Extension workers are worried that this might alter their rights and obligations as their "home" might be merged with other offices. During our fieldwork in the three districts, we indeed observed different conditions of the institutional restructuring of agricultural extension. 
The extension workers are generally highly interested in the topic of sustainable agriculture. This interest has been fostered by the district government of Bondowoso when they started a program to develop the region into an organic rice producing area in 2008. Within this program, extension workers received support and training to prepare the farmers to produce organically. As a result, the extension workers in this region started to value the environmental aspects of sustainable agriculture and proactively searched for additional information. From this moment onwards, their focus shifted to the environmental friendliness of agricultural production and potential benefits of this approach for human and environmental health. This approach however, stood miles away from the farmers who were mainly interested in economic benefits resulting from the adoption of organic practices. The information they received from the extension workers was not well adapted to their needs, concerns and knowledge demands, which made them rather resistant to change and to adopting organic practices. Extension workers acknowledged that they faced difficulties in convincing the farmers to adopt organic farming and reduce the use of chemical inputs. From the six areas that were targeted to become organic, only one area succeeded to receive organic certification ${ }^{22}$. The successful adoption of organic practices in this single region, can however mainly be explained through imitation behavior and the fact that farmers experience that organic agriculture can reduce the costs of production. Extension did not seem to have played an important role in the farmers' decisions to change their practices. One rice farmer said,

Organic rice farming is more cost-effective than traditional farming. At first, I did not want to apply organic practices. However, in this area more and more farmers started to adopt organic agriculture, so I decided to just follow my neighbor. Previously, I really did not believe that organic agriculture will increase our profit, but when I saw the results in my neighborhood, I thought it would not harm to try. The district government also promised to fund the operational cost (e.g., rice seedlings, fertilizer, irrigation) up to three times the harvest period (or about a year) for farmers who are willing to participate. That also helped me to decide to participate.

The mismatch between the extension workers' and farmers' perspectives on sustainable agriculture can also be recognized in the coffee sector in Bondowoso. As extension is institutionalized under the Agency of Agriculture and food crops, extension workers' focus is limited to rice. Therefore, there is no extension specifically adapted to coffee farmers in Bondowoso, and extension workers do not have much knowledge about coffee farming.

\footnotetext{
${ }^{22}$ Based on the interview with the coordinator of extension workers, 29 December 2016.
} 


\section{District 3: Pelalawan, Riau}

In Pelalawan (district 3) we cannot distinguish clear patterns as extension workers and farmers are both loaded rather equally across the two factors. In most cases (53\%) perspectives of extension workers and their farmers matched, although it also regularly happened that this was not the case (see appendix C). In terms of boundary work, we conclude that the extension workers in Pelalawan seem to perform rather well, although the system sometimes hinders their performance.

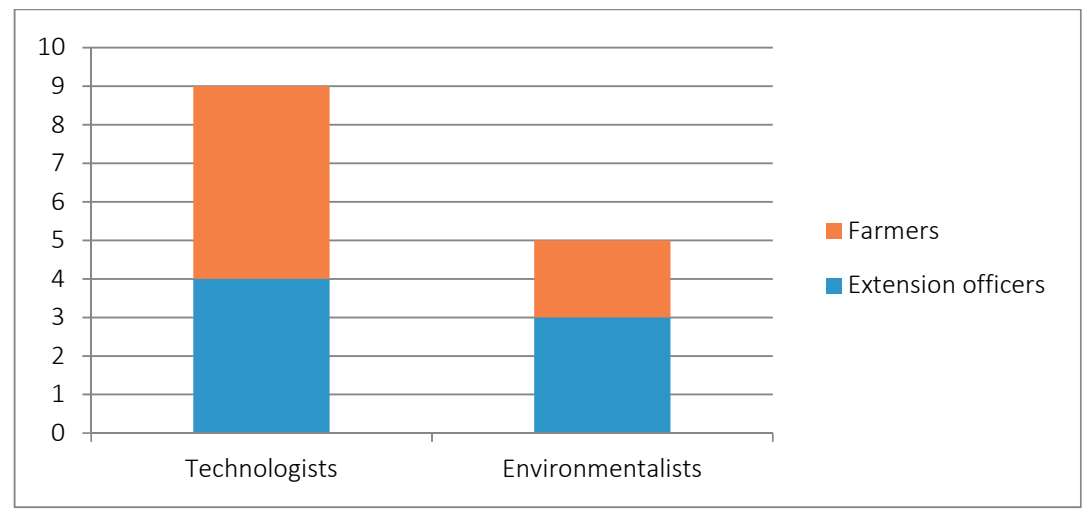

Figure 5.7 The loading of respondents in the two factors in Pelalawan.

Our general observation is that extension workers in this region can be considered highly motivated, but receive little support from the government and therefore struggle with understaffing and challenges that come along with it. Compared to the previous two districts, Pelalawan only employs one-third of the number of extension workers. Farmers' settlements in Pelalawan are also relatively scatered. This increases the extension workers' time spent, and efforts to visit farmers, which leaves less time to build strong relationships with farmers. Further, we found that extension workers in one subdistrict in Pelalawan do not even have a decent office or facilities to enable their work. Agricultural extension in general, is not a priority for the district government as the area of food crops and horticulture is relatively small compared to the vast area of palm oil. Next, the extension agency recently lost its status as an independent agency after merging with the Agency of agriculture. This caused uncertainty among extension workers and slowed down their working pace. These challenges imply that extension workers do not have a lot of time to advise and teach farmers, something that was also felt by one of the horticulture farmers,

[...] sorry to say this, but we (farmers) are stubborn. We know what we are doing. Our source of information is our experience on farm. Although some past experiences failed, we learn from that (trial and error). We tend to be reluctant in listening what other people (non-farmers) tell us. Although we say "yes", it does not mean 
that we will also act upon it (apply it). Nowadays, the farmers suffer more than they did during the previous regime as commodity prices declined and so on, but no solution comes from the government. For extension workers, well, they come to visit $[\ldots .$.$] we share experiences, but it is not much.$

Notwithstanding all challenges that make the boundary work in Pelalawan more difficult, we still find shared perspectives on sustainable agriculture among extension workers and farmers in Pelalawan. We see three reasons behind successful examples of boundary work here. The first one is that extension workers invested their scarce time to understand the farmers' local (Javanese) languages that smoothened communication and caused a feeling of connectedness. This situation subsequently provided a base of trust to get the farmers involved in a governmental program called "sustainable food home areas" that started around four years ago. This program targeted women farmer groups and aimed to grow plants in their home yards to assure self-sufficiency in food ${ }^{23}$. Through this program, extension workers introduced organic farming and taught every household in making organic fertilizer from organic waste, i.e., cattle manure. The community received this program well because of the clearly communicated economic advantages for families. Besides reduced costs, it could increase income by selling the over-supply of products.

\subsection{Conclusion}

This chapter enriches literature on boundary work by connecting the concept of boundary work to agricultural extension and focusing on the extent to which public extension workers succeed in fulfilling the role of boundary workers in sustainable agriculture. We conceptualized good boundary work as the ability to realize a similar perspective on sustainable agriculture between public extension workers and their respective farmers. Reflecting on the extent to which extension workers fulfill their roles as boundary workers in three districts, we derive some prerequisites for good boundary work.

First, motivation of extension workers. Motivation is often expressed through their satisfaction and pride after they succeed to help farmers to improve their farms, or through the attention they pay to farmers who grow cash crops that receive less attention from the government than food crops. Second, and related, extension workers should be able to connect to farmers and gain their trust. This means that extension workers should be able and willing to spend enough time to their work, and to learn the farmers' local languages. They also need to be motivated enough to be flexible and work outside office hours. Extension workers, who successfully connect to farmers, also

\footnotetext{
${ }^{23}$ Based on the interview with an extension worker, 16 January 2017.
} 
better succeed to provide knowledge that is understandable to, and useable for, farmers. A third prerequisite for good boundary work, touches upon the farmers' willingness to change their farming practices. We have seen that information provision and understanding are not sufficient to change the farmers' practices. Generally, farmers do seem to understand the danger of using chemical inputs, for example, but they keep using it in their farms (district 1, 2, and 3) as a matter of habit. Fourth, we found that government support (on the local level) is crucial for good boundary work. Support can take the form of the provision of operational allowances, or vehicles.

All these prerequisites were fulfilled in district 1 in which we also found large commonalities between the perspectives of extension workers and their respective farmers. In district 2 and 3 we found motivated extension workers who succeeded relatively well to translate abstract knowledge into salient information for the farmers. However, in these two districts it often happened that perspectives between extension workers and farmers did not align. Based on these cases, we identify three main obstacles that hinder extension workers in performing good boundary work. First, the geographical relocation of extension workers by the district government. Frequent relocations hamper boundary work in several ways. It limits the time in which extension workers can build trust with the farmers, develop social ties, and learn local languages (prerequisite 2). It also demotivates extension workers to leave regions before their plans and efforts become materialized in the field, and to leave communities to which they feel connected (prerequisite 1). Finally, it also hampers farmers' willingness to change their practices if they keep being confronted with new extension workers (prerequisite 3).

A second barrier towards good boundary work, regards the role and policies of district governments. We observed that local governments tend to prioritize profitable industry sectors over agriculture. Within agriculture, we subsequently see a prioritization of food crops (i.e. rice) over cash crops. This implies that extension workers in regions with cash crops receive little support in their work, resulting in inadequate infrastructures, minimum financial support, overload of administrative work, and severe understaffing. This constrains extension workers to connect to the farmers (pre-requisite 2), it undermines their pride (prerequisite 1 ), makes farmers more suspicious to follow the extension workers advice (prerequisite 3) and directly hampers support (pre-requisite 4).

Third, we see that Indonesia's history of the so-called green revolution seems to hamper farmers' willingness to change towards more sustainable practices (prerequisite 3). During the green revolution, the use of chemical fertilizer and technology was stimulated to achieve self-sufficiency in rice production. Consequently, many farmers still consider that governmental support in the form of fertilizers, pesticides and technologies is the only credible form of support to maintain their farms. This also makes it more difficult for extension workers to build trust (prerequisite 2).

This chapter identifies two perspectives on sustainable agriculture: the technologist and the environmentalist. Technologists pay less attention to the environmental aspects of sustainable agriculture and reflect the governmental policies during the green revolu- 
tion in the new order era. The majority of farmers load into this perspective and their attitude reveals high dependency on governmental projects and aids. Most farmers in this perspective are rice farmers. Meanwhile, the environmentalist perspective can be considered more similar to the understanding of sustainable agriculture that is prevalent among western consumers and private extension from NGOs and development organizations.

Prior to this research we expected that the characteristics of extension workers (i.e., years of experience) and farmers (i.e., certified or traditional farmers) would have an effect on people's perspective on sustainable agriculture. However, our results indicate that this is not the case. There is no evidence that certified farmers, or more experienced extension workers do value environmental aspect more than traditional farmers. All organic rice farmers, and part of the certified cocoa and palm oil farmers in our study are loaded into the technologist perspective. The extension workers in different age groups were nicely distributed along the two factors.

The results of this research imply that public extension workers remain necessary to improve the farmers' knowledge on sustainability. Private extension and training via certification schemes does not seem to result in a more environmentally friendly perspective on sustainable agriculture and their involvement is -compared to public extension worker- less certain on the long term. We furthermore found that the Indonesian government does not have a comprehensive guide on the definition or operationalization of sustainable agriculture that can be used by extension workers. Consequently, extension workers have to interpret the concept themselves. This may not only lead to confusion among farmers, but also to additional work load for the extension workers if they have to search for credible information on the concept of sustainable agriculture independently. Therefore, it is necessary for the Indonesian government to develop guidelines for extension workers about sustainable agriculture. 

Chapter

Conclusion and reflection 


\subsection{Introduction}

This dissertation studies the confrontation between a global value chain (GVC) approach and a domestic public approach in the process of realizing a more sustainable production of agricultural commodities in Indonesia. We are particularly interested in the different ways Indonesia claims its authority in the confrontation with Northern-based private standards and certifications. This process of 'claiming authority' creates many tensions as it is being realized in a decentralized and fragmented governance system through various institutional arrangements. In our research, we aim to answer the following research questions:

1. How and why is the Indonesian government involved in sustainability contestations in the agricultural production of plantation crops?

2. What challenges do these involvements create for the government and how does the government respond to these challenges?

3. What do these involvements imply for viable forms of government interference in the process of creating a more sustainable agricultural production?

The institutional arrangements we studied (see Table 6.1) unfold in a liberal market, in which governments from the South are not the most influential actors.

Table 6.1. Types of institutional arrangements studied in the dissertation

\begin{tabular}{|c|c|c|c|c|c|}
\hline \multirow[b]{2}{*}{$\begin{array}{l}\text { Institutional } \\
\text { arrangements }\end{array}$} & \multicolumn{2}{|c|}{ Chapter 2} & \multirow{2}{*}{$\begin{array}{c}\text { Chapter } 3 \\
\text { Development } \\
\text { partnership pro- } \\
\text { jects (SCPP) }\end{array}$} & \multirow{2}{*}{$\begin{array}{c}\text { Chapter } 4 \\
\text { Mediated } \\
\text { partnership } \\
\text { (Motramed) }\end{array}$} & \multirow{2}{*}{$\begin{array}{l}\text { Chapter } 5 \\
\text { Extension }\end{array}$} \\
\hline & $\begin{array}{l}\text { RSPO private } \\
\text { certification }\end{array}$ & $\begin{array}{l}\text { ISPO public } \\
\text { certification }\end{array}$ & & & \\
\hline Initiator & Top-down & Top-down & Top-down & Bottom-up & Top-down \\
\hline Scale & International & National & $\begin{array}{l}\text { - International } \\
\text { - } \text { National } \\
\text { - } \text { Regional/local }\end{array}$ & Regional/local & $\begin{array}{l}\text { - } \quad \text { National; } \\
\text { - } \text { Regional/ } \\
\text { local }\end{array}$ \\
\hline Tensions & $\begin{array}{l}\text { - Public and } \\
\text { private re- } \\
\text { sponsibility } \\
\text { - Global and } \\
\text { local values } \\
\text { - Knowledge } \\
\text { to practice }\end{array}$ & $\begin{array}{l}\text { Knowledge } \\
\text { to practice }\end{array}$ & 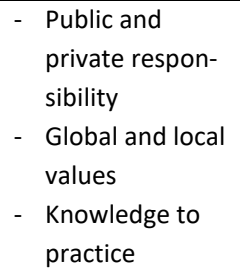 & 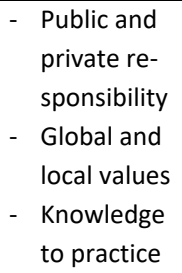 & 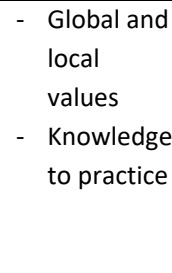 \\
\hline
\end{tabular}

Private standards, certification schemes, and (some) partnership development projects, are generally initiated by Northern-based actors at the top of the value chain. The standards of these initiatives are channeled downward as new production requirements to Southern producers. At this level, different interests and interpretations of sustainable agricultural production from public and private actors meet and need to be reconciled. 
As an example of the bottom-up institutional arrangements, we analyzed the socalled mediated partnership projects, initiated by local actors at producer's level in Indonesia. These initiatives might be seen as a feasible alternative to top-down arrangements, with the same aim of creating more sustainable agricultural production. These bottom-up arrangements focus on a restricted definition of sustainability, mainly on realizing economic profit as the first step in the process of change, and they are applied in smaller regions, for example at district level.

The first chapter of this dissertation suggested that the confrontation between a GVC approach and a domestic public approach may create three major tensions for related stakeholders, including farmers, which manifest themselves differently in top-down and bottom-up institutional arrangements.

The first tension regards the distribution of responsibilities between public and private actors on an international level. Public actors are commonly thought to be the proper authority to regulate agricultural production. The emergence of private sustainability standards and certification schemes challenges this authority. In Chapter 2 we have seen that the implementation of these schemes affects global trade as well as the policies of the Southern countries. In Indonesia, the national government reacted with the development of its own national standards and certification schemes.

The tension between public and private actors also manifests itself, but in a different way, at the local level; for example in development projects, when Northern-based actors direct farmers to comply with sustainability standards and change their practices. Such projects may create ambivalence and uncertainty for both farmers and local governments regarding who they should follow and which requirements. Our research in Chapter 3 reveals forms of miscommunication and lack of coordination between involved governmental agencies and the private initiators of the projects because of different organizational cultures. While local governments demand bureaucratic procedures and formal interactions, private actors, including non-governmental organizations (NGOs), tend to work more pragmatically to achieve sustainable change. However, in Chapter 4 we have seen a better relationship between local governments and local private actors (exporters). In these bottom-up partnerships, the responsibilities between public and private actors are fairly distributed, based on their role and resources in the partnerships.

The second and related tension regards frictions between global and local values. The top-down initiatives from the North accentuate environmental aspects of agricultural production in particular. However, this framing of a more sustainable production tends to be different from the one at the producer level. For farmers, short-term economic profit and access to capital are the most essential aspects. Our research, particularly in chapters 3 and 5, shows that farmers are willing to apply more sustainable farming practices and change their farming habits if this could improve their livelihood condi- 
tions. If not, they will generally be less interested. This is also the case with certification schemes, as it is not always evident that the schemes will bring much economic profit for farmers.

The tension between global and local values is also visible when private sustainability standards are interpreted in - and related to - domestic laws and regulations. Chapter 2 shows interpretation frictions between the principles and criteria (P\&C) of the Roundtable on Sustainable Palm Oil (RSPO) and Indonesian laws. The exclusion of local producers and their knowledge in the development of private regulations is generally considered as contributing to this tension and leading to uncertainty about conflicting guidelines due to unrepresented producers' values in the development of the standards.

The bottom-up initiatives that we studied in Chapter 4 reveal another pattern. In these initiatives, global sustainability values are introduced to the producers in an indirect way. They are introduced as part of a new coffee processing procedure which complies with exporter and consumer demands in the global coffee market. Thus, global sustainability values are wrapped in economic incentives that attract farmers to change their practices.

The third tension is related to the translation of knowledge into practice. Knowledge on sustainable production methods is quite abstract and therefore complicated and challenging for low-educated farmers to apply. Farmers even experience sustainable farming practices as burdensome. In Chapter 2, we observed why the RSPO's P\&C are hard to accept by palm oil actors in Indonesia. The P\&C are too difficult to apply for smallholders, and only palm oil companies can apply them on their plantations.

In Chapter 3 we have seen that the main activity of the partnership projects is training farmers and extension officers to translate sustainability knowledge into good agricultural practice (GAP) on cocoa plantations and also to promote cocoa sustainability certification schemes. Farmers are willing to apply the GAP only when it is proportional to its economic benefit for them. In Chapter 4, we observed that farmers became motivated to change because of the help of government staff, researchers and exporters, besides the economic incentive. The presence of a mediator who is able to bridge the different interests is crucial to the partnering process.

In Chapter 5 we explored the role of public extension workers as boundary workers translating the abstract sustainability concept into concrete farming practices. We have seen that the process of knowledge transfer does not necessarily result in knowledge adoption by farmers and changes in their daily farming practices. Although farmers understand the risks of unsustainable agriculture, we again see that their willingness to change is strongly determined by the economic prospects of sustainable farming. Extension officers are able to minimize the tension between theory and practice at the producer's level. However, they face many challenges, such as limited resources and lack of 
support from the local governments that negatively influence their performance as boundary workers.

\subsection{Forms of claiming government authority}

Regarding our first research question - forms of government involvement -, we observe a noticeable difference between the national government and local governments. At the national level, as shown in Chapter 2, the government reclaims its authority over private standards and certification through the development of alternative and competing public regulations on palm oil, coffee and cocoa. A different form of claiming national authority became apparent in our research of the partnership projects where an NGO collaborates with the district government. These partnership projects are currently being developed in many districts in Indonesia. As a reaction, the national government tried to claim its authority in these types of arrangements by indirectly regulating the activities of international civil society organizations in Indonesia. Through a Memorandum of Understanding (MoU) at the national level between the NGO and the ministries, the government strengthened its grip on these arrangements. With this $\mathrm{MoU}$, the national government involves more governmental offices at the national and provincial level, changing the flow of information and the coordination of the projects.

Our research at the local level reveals a different way of claiming government authority. In general, local governments seem to be more pragmatic in their reaction to external attempts to induce a more sustainable agricultural production. They are more inclined to consider what would serve their own interests, such as regional economic growth and resources for regional development, even though the progress of the projects differs from district to district. We also observed some animosity between district governments and provincial governments, as district officials tend to operate more or less independently of provincial policies. As shown in Chapter 4, local governments play a more active role in the mediated partnership projects, as it is ensured that the project activities fit into their regional strategy and policies. In these cases, the local governments and other actors together set the agenda to realize collective advantages, with local governments actively involved in the implementation process. These bottom-up arrangements do not necessarily depend on - or coordinate with - higher levels of government. Other than partnerships at the national level, which tend to lead to complex multi-level coordination problems, local governments can work in smaller scope projects in which all involved parties can explore their respective advantages. A similar pattern became visible in Chapter 5, which shows that the support of local governments influences the performance of agricultural extension in the region. Since the decentralization period, extension is determined by the interests of local governments in the de- 
velopment of the agricultural sector in their region. Consequently, the quality of extension services differs from region to region. With the support of local governments, extension workers are more motivated to perform their role as boundary workers than if they were not to receive any support.

\subsection{Factors impeding sustainability change}

Regarding our second research question, challenges and responses, we observe that various problematic issues hinder the process of developing government authority for a more sustainable agricultural production of plantation commodities such as coffee, cocoa, and palm oil.

First, the overly formal and bureaucratic process in governmental offices may slow down the progress. In the public-private partnership projects (Chapter 3), we have seen that the slow progress of the projects since the national MoU was issued is due to the formal and bureaucratic way that governments function. As mentioned earlier, the differing organizational cultures of governments and NGOs tend to prevent collaboration. Government also tends to work slower than NGOs because in the Indonesian context all policy issues have to be formally discussed, while in the field decisions often need to be made quickly. These issues also raise doubts about the future of public standards (see Chapter 2). The implementation of public standards requires the involvement of provincial and district level governments and ministerial level staff. A multi-level governance approach seems to be difficult to realize in Indonesia where the decentralization process is still accompanied by many uncertainties. In the current situation, decentralization encourages the local governments to develop priorities other than those at the national level. The same concern can be expressed regarding the future development of the bottom-up mediated partnership model (see Chapter 4). The positive achievements of this model seem to have encouraged the national government to consider a nation-wide program. However, the overly formal and bureaucratic procedures that the implementation of such a national program may very well imply, might only further complicate the implementation of these partnerships.

Second (and related), we observed problematic communication and coordination between governmental offices in Indonesia. Most of the cases in this dissertation show problematic communication between governmental offices at the same level and between offices at different levels. In Chapter 3, the partnership projects on cocoa sustainability engaged the Indonesian government in a multi-level governance trajectory. However, the study shows that involving many governmental offices does not necessarily result in clearer flows of information and effective coordination of the partnership. In fact, not all governmental offices were active, nor did they understand their role in the 
partnership, and this slowed down the work in the field, for example due to the NGO's field staff being required to continuously report their progress to many governmental officials. Among governmental offices at provincial and district levels, we also observed little consensus related to the integration of the partnerships into their regional policies and work plan, although the objective and mechanism of partnering is agreed in the national MoU. In Chapter 4 we have seen that the stagnant implementation of the mediated partnerships on coffee development at the provincial level is mainly due to the reluctance of certain district governments to follow the instructions of the upper-level governments. The decentralization process enables local governments to freely develop their region and to decide themselves on their resources. Consequently, it also enables the district governments not to follow the upper-level government policies and not to support the implementation of mediated partnerships. In Chapter 5, the study of extension workers shows that a lack of coordination among agricultural agencies specialized in different commodities at the district level negatively influences the extension work. In Indonesia, agricultural responsibilities are divided among offices according to commodity characteristics, for example, food crops, plantation, livestock, and horticulture. In practice, the extension system in Indonesia focuses more on food crops than on other commodities because district-level extension workers work under the agricultural agency for food crops. Moreover, the plantation offices work independently, do not communicate with each other and do not coordinate their activities.

Third, the bureaucratic process goes together with a very personalized way of governing, in the sense that it is important to know the right people to effectively find your way in the bureaucracy. In Indonesia, the vision and priorities of governmental leaders determine the implementation of - and responses to - rules and regulations in topdown and bottom-up initiatives. As we can see from chapters 3 and 4, the implementation of partnerships is only successful if it is supported by active government officials who are engaged in the process. Active involvement of the government cannot be separated from the willingness of governmental leaders to engage in such arrangements with other actors. Our research shows why governmental leaders disregard the idea of mediated partnership and purposely do not participate in such arrangements, which resulted in stagnating progress and sometimes even failure. Chapter 5 also confirms the influence of individual governmental leaders on the performance of the agricultural sector, that is via the extension system. The support from motivated governmental leaders encouraging extension workers to perform better will accelerate the change towards a more sustainable agriculture.

Fourth, the restricted definition of sustainability that Southern actors adhere to may pose a barrier to achieve a more sustainable agricultural system. Sustainability standards interpreted by the Northern actors mainly serve the consumers' interests in an environmentally friendly and socially responsible production. The Southern actors tend to 
consider these aspects as less important than economic profit. We have seen this in Chapter 3: farmers are willing to participate in training to increase cocoa sustainability because they are attracted by the short-term economic benefits. These benefits also determine the willingness of farmers to participate in private certification schemes. The bottom-up arrangements studied in Chapter 4 show that this barrier may be overcome if economic success is considered a precondition for the realization of environmental and social benefits.

Fifth, the Indonesian government gives less priority to export-oriented commodities (coffee and cocoa) compared to rice. In the current regime, the Minister of Agriculture launched a program of self-sufficiency in rice, maize, and soy, which shows that highproductivity food crop commodities are seen as an indicator of agricultural development in Indonesia. This national program disseminates into the local level and its extension system. Therefore, at the district levels that we studied extension workers only assist food crops farmers, but hardly assist plantation farmers. In fact, the lack of attention to plantation farmers is one of the reasons why the Northern actors target Indonesian plantations in their training projects and developmental aid. However, these Northern initiatives may not be very effective without a clear vision of the national government on the development of plantation agriculture.

\subsection{On potential futures}

Regarding our third research question, interference of the government in processes towards a more sustainable agriculture, we observed that the liberalization of the commodity market created asymmetric power relations between global private sustainability schemes and Southern governments. Although Indonesia originally accepted this consequence of a liberalized market, it later rejected it as an unacceptable interference in its economy. At the national level, this resulted in counter-initiatives in the form of the development of public standards and certifications. In contrast, at the local and regional levels, governments play a more active role, particularly in bottom-up institutional arrangements. In the bottom-up arrangements, the government is involved throughout the process, from the agenda-setting stage onwards, to determine a common problem and define collaborative advantages. This creates a sense of ownership regarding the arrangements, with local governments willing to be more active to achieve a more sustainable agricultural production.

Reflecting on these findings, we consider three potential futures for the Indonesian government (as well as for Southern governments in general) in their attempts to encourage more sustainable production of agricultural commodities. 


\section{A. Accommodating the global market}

The first future might be engaging with privately initiated arrangements through sustaining activities. In that case the government would accept the inevitable power of the liberal market to define production requirements. The Indonesian government has limited resources (staff, finances, and knowledge), which makes it difficult to manage the agricultural sector in a sustainable fashion without the cooperation of market actors. Table 1 in Chapter 1 illustrates the potential roles that the government might fulfill. If systematically employed and embedded in a better communication between the government and the private actors, the private standards and certifications might gain strength. In this approach the government could try to become more closely involved in the further development of the schemes and could also try to realize increased harmonization and equivalence between the standards. Regarding the roles indicated in the aformentioned table, particularly adapting the domestic legal regulations, communicating the schemes to farmers and developing a sustaining extension system seem to be crucial. However, it is questionable whether the market approach will be able to create a system change. Currently there is already an oversupply of certified products on the market. Moreover, accepting the market approach does not change the power of price setting of the products, which is currently in favour of actors further up the value chains.

\section{B. Countering the global market}

The second future might be developing and ensuring the implementation of national public sustainability standards. With the development of sustainable standards and certification schemes for palm oil (ISPO), coffee (ISCoffee) and cocoa (ISCocoa) Indonesia is a leading country in this regard. These top-down public arrangements have more legal enforcement power than the private standards. With these public standards, the attempt to create a more sustainable production nation-wide is also expected to be achieved faster. But the public standards are less strict than the private ones which could mean that a low level of sustainability is the result. Moreover, in maintaining public standards the government needs to ensure that the system to implement the standards is well prepared, with adequate human resources, certification bodies, and clear procedures to follow. Our own research and related research by members of our research team (Hidayat et al., 2017; Ibnu et al., forthcoming) indicate that the implementation capacity of the Indonesian government is still limited, particularly if it requires multi-level governance. Whether the international markets will accept the public certifications as reliable schemes is also open to doubt. We expect that the latter 
may find their way in the Asian market, yet not in the western market, which seems to prefer and trust the private schemes more.

\section{Fostering the partnership model}

The third future might be fostering the partnership model, for example through the development of bottom-up mediated partnerships in a national program. The bottomup arrangements that we discussed in Chapter 4 are quite successful in some regions. However, upscaling them to the national scale to reach more regions may also create more of the implementation problems already discussed. Successful partnership projects require a power balance between private and public actors, the integration of the partnerships into government policies, and the elimination of communication problems, both between government offices and private actors and among government offices themselves, in order to create a more coherent coordination mechanism that supports the partnerships. Besides the many implementation problems that could arise, this approach requires a decentralized system which functions better and a reformed extension system. As a result, we do not see how a sector change can be realized through thousands of very intensively orchestrated local arrangements as found in the current system.

In the period we conducted our dissertation research some new approaches were initiated that may change the roles of the government or create additional roles. Recent discussion on a more sustainable agriculture is focused on how to transcend sustainability standards and certification schemes, with several scholars arguing for an alternative model that could induce more sustainable production methods. These new approaches include the FAIR partnerships, the landscape approach, and the jurisdictional approach (Beekmans, Molenaar, \& Dallinger, 2014; Ros-Tonen, Sunderland, \& Laven, 2015; Mallet et al., 2016). In these approaches, certification schemes are considered as parts of a theory of change, not as its the main agenda. These approaches are mainly discussed in relation to palm oil. In this dissertation, we also studied other plantation commodities, that is coffee and cocoa. The three commodities have different plant and farmer characteristics. However, the basic idea of the new approaches might be suitable for all plantation commodities.

The FAIR (company-community) partnership, initiated by Oxfam Novib and palm oil stakeholders in 2014, is based on the idea of connecting smallholders and host communities as partners to oil palm companies (mills), to support existing sustainable standards, that is RSPO. The FAIR partnership is based on four principles: freedom of choice, accountability, improvement, and respect for rights (for a more detailed explanation see Verburg, 2014). The landscape approach aims to balance biodiversity and rural development through multi-stakeholder negotiations. Although such a multi-stakeholder 
initiative is not new, the landscape approach offers a more comprehensive approach, given that it is not restricted to single commodities, but engages all commodities and other related aspects within certain geographical spaces, and links to the global supply chain (see Ros-Tonen et al., 2015; Sayer et al., 2014). Both approaches are rather similar in their objective of farmer inclusion, stimulating concerted action among stakeholders, and realizing benefits for farmers, the environment, and the community. Both national and local government fulfill a crucial role in these approaches. The government should play a role in creating an enabling environment for these approaches through its policies and regulations (Beekmans et al., 2014; Verburg, 2014); for example, on land tenure regulations for farmers and on protection of natural resources. The policies should be coherent at both national and local levels. In addition, the government needs to ensure the transparent enforcement of these policies and regulations. The FAIR partnership and the landscape approach emphasize the benefits for the communities, not just farmers. Therefore, the policies also need to consider the benefits for all stakeholders, that is farmers, companies, and communities. Although certification schemes and development projects also refer to social aspects, the benefits for the surrounding communities are often not clearly addressed and evaluated. The government may stimulate the communities to participate in the agenda-setting and decision-making process. The local government could play a mediator role, facilitating the interest of communities (including farmers) and companies.

Together with the landscape approach, the recent discussion regarding sustainable palm oil is also about the jurisdictional approach. The jurisdictional approach encourages the implementation of palm oil certification at the provincial level in the form of a rural development model. This approach aims to reduce deforestation and greenhouse gas emissions, and to improve the welfare of society. The landscape approach and the jurisdictional approach have a similar idea in covering a greater scope of areas, commodities, and action. However, in the jurisdictional approach, the government adopts a role as a leader and uses the government's administrative boundaries to determine the scope of program, that is the stakeholders' role and involvement (Mallet et al., 2016).

The three approaches show the importance of the role of the Southern governments - as these are the producing countries - in ensuring the implementation of the new approaches. Up to now these approaches have been experimentally applied. It is still uncertain whether they may ever be up-scaled and become more than ad hoc attempts to change the agricultural production methods for the better. As they strongly rely on multi-level governance, they will be confronted with all the impeding factors discussed earlier in this chapter.

All of these approaches seem not to be able to transform traditional production methods in sustainable ones on their own. In our view, a viable theory of change would explore how the approaches can be related to each other as parts of a more elaborated 
approach. This approach would primarily seek connections between the strengths of the different ways forward. This, however, requires an overall national vision on the future of the production of agricultural commodities, strong strategic thinking, as well as the development of an operational implementation strategy. Such an approach cannot be developed by a single government agency, at one level, or only by public actors. It requires a national public-private multi-stakeholder platform to foster the dialogue, such as initiated by the UNFSS (United Nation Forum on Sustainability Standards) in India, and upcoming initiatives in Brazil and China (Hoffmann, 2016, p. 37). In Indonesia, the recently formed PISAgro platform, initiated by the World Economic Forum, may play a role in this area (http://www.pisagro.org). Regarding follow-up research, we suggest connecting to this integration attempt and working out the relationships between the different ways forward in scenarios based on an overall vision regarding more sustainable agricultural commodity production. 


\section{References}

Abdulsamad, A., Stokes, S., \& Gereffi, G. (2015). Public-private partnerships in global value chains: Can they actually benefit the poor? LEO Report \#8: United States Agency for International Development (USAID).

Anderson, A. A. (2005). The community builder's approach to theory of change: A practical guide to theory development. New York, United State: The Aspen Institute Roundtable on Community College. http://www.dochas.ie/Shared/Files/4/TOC_fac_guide.pdf. Accessed 27 May 2015.

Anggraini, E., \& Grundmann, P. (2013). Transactions in the supply chain of oil palm fruits and their relevance for land conversion in smallholdings in Indonesia. The Journal of Environment \& Development, 22(4), 391410.

Ansel, C., \& Gash, A. (2008). Collaborative governance in theory and practice. Journal of Public Administration Research and Theory, 18(4): 543-571.doi: 10.1093/jopart/mum032

Antara, M., \& Efffendy (2009). Karakteristik petani kakao dan produksinya di Kabupaten Parigi Moutong. Jurnal Agrisains, 10(1), 1-9.

Arifin, B. (2008). From remarkable success stories to troubling present: The case of BULOG in Indonesia. Shahidur, R. Gulati, A. and Cummings, RW; Jr.(Eds), From parastatals to private trade: Lessons from Asian agriculture, 137-164.

Arifin, B. (2010). Global Sustainability Regulation and Coffee Supply Chains in Lampung Province, Indonesia. Asian Journal of Agriculture and Development, 7(2), 67.

Astuti, E. S., Offermans, A., Kemp, R., \& Cörvers, R. (2015). The impact of coffee certification on the economic performance of Indonesian actors. Asian Journal of Agriculture and Development, 12(2).

Auld, G. (2010). Assessing certification as governance: Effects and broader consequences for coffee. Journal of Environment and Development, 19 (2): 215-241.

Auld, G., Renckens, S., Cashore, B. (2015). Transnational private governance between the logics of empowerment and control. Regulation \& Governance, 9, 108-124.

Austin, J. E., \& Seitanidi, M. M. (2012). Collaborative value creation: A review of partnering between nonprofits and businesses: Part I. Value creation spectrum and collaboration stages. Nonprofit and Voluntary Sector Quarterly, 0899764012450777.

Bäckstrand, K. (2006). Multi-stakeholder partnerships for sustainable development: rethinking legitimacy, accountability and effectiveness. European Environment, 16, 290-306.

Badrun, M. (2013). Oil palm-based agriculture: From waste towards blue economy. Jakarta, Indonesia: In collaboration with GAPKI.

Bangun, D. (2010). Memoirs "Ambassador" of the Indonesian oil palm. Jakarta, Indonesia: Kompas publisher.

Bappebti (2012). Cocoa prices fell $30 \%$ in 2011. Jakarta, Indonesia: Ministry of Trade. http://www.bappebti.go.id/en/news/commodity/detail/1744.html. Accessed 27 May 2015.

Barbour, R. S. (2007). Doing focus groups. Los Angeles, CA: Sage Publications.

Barroso-Méndez, M.J., Galera-Casquet, C., Seitanidi, M.M., \& Valero-Amaro, V. (2016). Cross-sector social partnership success: A process perspective on the role of relational factors. European Management Journal 34 (6): 674-685.

Barry, J., \& Proops, J. (1999). Seeking sustainability discourses with Q methodology. Ecological Economics, 28(3), 337-345.

Bartley, T. (2010). Certification as a mode of social regulation. Jerusalem Chapters in Regulation and Governance, Working Chapter No. 8.

Bartley, T. (2011). Transnational governance as the layering of rules: Intersections of public and private standards. Theoretical inquiries in law, 12(2), 517-542.

Bartley, T. (2014). Transnational governance and the re-centered state: Sustainability or legality? Regulation \& Governance, 8, 93-109.

Beekmans, A., Molenaar, J. W., \& Dallinger, J. (2014). Fair company - community partnerships in palm oil development. Oxfam International and AidEnvironment. 
Benson, A., \& Jafry, T. (2013). The state of agrocultural extension: an overview and new ceveats for the future. The Journal of Agricultural Education and Extension, 19(4), 381-393.

Bernstein, S., \& Hannah, E. (2008). Non-state global standard setting and the WTO: Legitimacy and the need for regulatory space. Journal of International Economic Law, 11, 575-608.

Birner, R., Davis, K., Pender, J., Nkonya, E., Anandajayasekeram, P., Ekboir, J., . . . Cohen, M. (2009). From Best Practice to Best Fit: A Framework for Designing and Analyzing Pluralistic Agricultural Advisory Services Worldwide. The Journal of Agricultural Education and Extension, 15(4), 341-355. doi:10.1080/13892240903309595

Birner, R., \& Resnick, D. (2010). The Political economy of policies for smallholder agriculture. World Development, 38(10), 1442-1452.

Bitzer, V. (2012). Partnering for change in chains: The capacity of partnerships to promote sustainable change in global agrifood chains. International Food and Agribusiness Management Review, 15 (Special Issue B).

Bitzer, V. (2016). Incentives for enhanced performance of agricultural extension system. KIT Working Paper 2016:6.

Bitzer, V., Francken, M., \& Glasbergen, P. (2008). Intersectoral partnerships for a sustainable coffee chain: Really addressing sustainability or just picking (coffee) cherries? Global Environmental Change 18(2): 271-284.

Bitzer, V., \& Glasbergen, P. (2010). Partnerships for sustainable change in cotton: An Institutional analysis of African cases. Journal of Business Ethics, 93(2), 223-240.

Bitzer, V., Glasbergen, P., \& Arts, B. (2013). Exploring the potential of intersectoral partnerships to improve the position of farmers in global agrifood chains: findings from the coffee sector in Peru. Agricultural Human Values 30: 5-20. Doi: 10.1007/s10460-012-9372-z

Bitzer, V., Glasbergen, P., \& Leroy, P. (2012). Partnerships of a feather flock together? An analysis of the emergence of networks of partnerships in the global cocoa sector. Global Networks: A Journal of Transnational Affairs, 12(3), 355-374.

Bitzer, V., \& Glasbergen, P. (2015). Business-NGO partnerships in global value chains: Part of the solution or part of the problem of sustainable change? Current Opinion in Environmental Sustainability, 12(0), 35-40.

Boezeman, D., Vink, M., \& Leroy, P. (2013). The Dutch Delta Committee as a boundary organisation. Environmental Science \& Policy, 27, 162-171. doi:https://doi.org/10.1016/j.envsci.2012.12.016

Boons, F., Baumann, H., \& Hall, J. (2012). Conceptualizing sustainable development and global supply chains. Ecological Economics, 83, 134-143.

Brandi, C., Cabani, T., Hosang, C., Schirmbeck, S., Westermann, L., \& Wiese, H. (2015). Sustainability standards for palm oil: Challenges for smallholder certification under the RSPO. Journal of Environment \& Development, 24(3), 292-314.

Brewer, B., \& Haylarr, M.R. (2005). Building public trust through public-private partnerships. International Review of Administrative Sciences 71(3): 475-492. doi:10.1177/0020852305056825

Brinkerhoff, J.M. (2002). Government-nonprofit partnership: a defining framework. Public Administration and Development 22(1): 19-30. doi:10.1002/pad.203

Brinkerhoff, D. W., \& J. M. Brinkerhoff. (2011). Public-Private Partnerships: Perspectives on purposes, publicness, and good governance. Public Administration and Development, 31: 2-14.

Bureau, J-C., Jean, S., \& Matthews, A. (2005). The consequences of agricultural trade liberalization for developing countries: Distinguishing between genuine benefits and false hopes. CEPII Working Paper No 2005-13.

Busch, L. (2014). Governance in the age of global markets: challenges, limits, and consequences. Agriculture and Human Values : Journal of the Agriculture, Food, and Human Values Society, 31(3), 513-523.

Bush, S. R., Oosterveer, P., Bailey, M., \& Mol, A. P. J. (2014). Sustainability governance of chains and networks: a review and future outlook. Journal of Cleaner Production, 107, 8-19.

Bush S.R., Oosterveer P., Mol A.P.J., Kusumawati R., Belton B., Hall D., ... Ha T.T.T. (2013). Certify sustainable aquaculture? Science, 341(6150), 1067-1068.

Caroko, W., Komarudin, H., Obidzinski, K., \& Gunarso, P. (2011). Policy and institutional framworks from the development of palm-oil based biodiesel in Indonesia. Bogor, Indonesia: CIFOR. 
Cash, D. W. (2001). "In order to aid in diffusing useful and practical information": Agricultural extension and boundary organizations. Science, Technology \& Human Values, 26(4), 431-453.

Cash, D. W., Clark, W. C., Alcock, F., Dickson, N. M., Eckley, N., Guston, D. H., . . Mitchell, R. B. (2003). Knowledge systems for sustainable development. Proceedings of the National Academy of Sciences, 100(14), 8086-8091.

Cashore, B., Auld, G., Newsom, D. (2004). Governing through markets: Forest certification and the emergence of non-state authority. Yale University Press, New Haven.

Central Bureau of Statistic of Indonesia. (2014). The statistic of cocoa plantation in Sulawesi. Sulawesi: Indonesia.

CGIP, Community of Geographical Indication Protection of Bali Kintamani Coffee. (2007). The requirements book of Geographical Indication. Bali: Indonesia.

CGIP, Community of Geographical Indication Protection of Bajawa Flores Arabica Coffee. (2011). The requirements book of Geographical Indication. Flores: Indonesia.

Cheyns, E. (2014). Making "minority voices" heard in transnational roundtables: the role of local NGOs in reintroducing justice and attachments. Agriculture and Human Values, 31(3), 439-453.

Chiputwa, B., Spielman, D. J., \& Qaim, M. (2015). Food Standards, Certification, and Poverty among Coffee Farmers in Uganda. World Development, 66, 400-412. doi:https://doi.org/10.1016/j.worlddev. 2014.09.006

Clark, W. C., Tomich, T. P., van Noordwijk, M., Guston, D., Catacutan, D., Dickson, N. M., \& McNie, E. (2011). Boundary work for sustainable development: Natural resource management at the Consultative Group on International Agricultural Research (CGIAR). Proceedings of the National Academy of Sciences, 200900231.

Cuppen, E. (2010). Putting perspective into participation: Constructive conflict methodology for problem structuring in stakeholder dialogues. (Doctoral), Vrije Universiteit Amsterdam, Rotterdam: The Netherlands.

Curry, R., Barry, J., \& McClenaghan, A. (2013). Northern Visions? Applying Q methodology to understand stakeholder views on the environmental and resource dimensions of sustainability. Journal of environmental planning and management, 56(5), 624-649.

Coe, N.M., Dicken, P. \& Hess, M. (2008). Global production networks: realizing the potential. Journal of Economic Geography 8(3): 271-295. doi:10.1093/jeg/lbn002

Dijk, M. P. van, Trienekens, J., \& European Association of Development Research and Training Institutes. (2012). Global value chains: Linking local producers from developing countries to international markets. Amsterdam: Amsterdam University Press. http://site.ebrary.com/id/10537748

Dingwerth, K., \& Pattberg, P. (2009). World politics and organizational fields: The case of transnational sustainability governance. European Journal of International Relations, 15(4), 707-743.

Directorate General of Estate Crops. (2011). A Strong determination to implement ISPO announced on the celebration of 100 years oil palm industry. Retrieved from http://ditjenbun.pertanian.go.id/tanhun/ berita-173-tekad-untuk-menerapkan-ispo-telah-dicanangkan-pada-peringatan-semarak-100-tahunindustri-kelapa--saw.html.

Directorate General of Estate Crops. (2012). Pedoman Umum Gerakan Nasional Peningkatan Produksi dan Mutu Kakao. Jakarta: Ministry of Agriculture.

Directorate General of Estate Crops. (2013). The importance of ISCOffee (Indonesian Sustainable Coffee). Retrieved from http://ditjenbun.pertanian.go.id/pascapanen/berita 214-pentingnya-iscoffee-indonesiansustainable-coffee.html.

Directorate General of Estate Crops. (2015, December). Data statistik pertanian 2015. Retrieved from http://aplikasi.pertanian.go.id/bdsp/index.asp

Djohan, D. (2014). Merajut otonomi daerah pada era reformasi : kasus Indonesia / Djohermansyah Djohan; editor, Zumrizal Labolo. Jakarta Pusat: Ikatan Keluarga Alumni Pendidikan Tinggi Kepamongprajaan.

Douma, M., \& van Wijk, J. (2012). ASC certified shrimp: Can extensive shrimp farming benefit? A case study of Indonesia. Working chapter No. 2012/46. Maastricht School of Management.

Ellis, G., Barry, J., \& Robinson, C. (2007). Many ways to say 'no', different ways to say 'yes': applying Qmethodology to understand public acceptance of wind farm proposals. Journal of environmental planning and management, 50(4), 517-551. 
Elsey, B., \& Sirichoti, K. (2002). The Learning Facilitation Role of Agricultural Extension Workers in the Adoption of Integrated Pest Management by Tropical Fruit Growers in Thailand. Studies in Continuing Education, 24(2), 167-180. doi:10.1080/0158037022000020974

Emerson, K., Nabatchi, T. \& Balogh, S. (2011). An Integrative Framework for Collaborative Governance. Journal of Public Administration Research and Theory 22(1): 1-29. doi:10.1093/jopart/mur011

European Palm Oil Alliance. (2016). Palm oil production 2016. http://www.palmoilandfood.eu/en/palm-oilproduction.

Fahmid, I. M. (2013). Cocoa farmers performance at highland area in South Sulawesi, Indonesia. Asian Journal of Agriculture and Rural Development, 3(6), 360-370.

FAO. (2014). Impact of international voluntary standards on smallholder market participation in developing countries - A Review of the Literature. Rome.

Faure, G., Desjeux, Y., \& Gasselin, P. (2012). New Challenges in Agricultural Advisory Services from a Research Perspective: A Literature Review, Synthesis and Research Agenda. The Journal of Agricultural Education and Extension, 18(5), 461-492. doi:10.1080/1389224x.2012.707063

Feder, G., Murgai, R., \& Quizon, J. B. (2004). The Acquisition and Diffusion of Knowledge: The Case of Pest Management Training in Farmer Field Schools, Indonesia. Journal of Agricultural Economics, 55(2), 221243. doi:10.1111/j.1477-9552.2004.tb00094.x

Fuchs, D., Kalfagianni, A., Clapp, J., \& Busch, L. (2011). Introduction to symposium on private agrifood governance: values, shortcomings, and strategies. Agriculture and Human Values, 28(3), 335-344. doi:10.1007/s10460-011-9310-5

Fuchs, D., Kalfagianni, A., \& Havinga, T. (2011). Actors in private food governance: The legitimacy of retail standards and multistakeholder initiatives with civil society participation. Agriculture and Human Values, 28(3), 353-367.

GAPKI. (2013). About GAPKI. Retrieved from the Indonesian palm oil association website http://www.gapki.or.id/Page/About.

Garforth, C., Angell, B., Archer, J., \& Green, K. (2003). Fragmentation or creative diversity? Options in the provision of land management advisory services. Land Use Policy, 20(4), 323-333. doi:http://dx.doi.org/ 10.1016/S0264-8377(03)00035-8

Giessen, L., Burns, S., Sahide, A., \& Wibowo, A. (2016). From governance to government: The strengthened role of state bureaucracies in forest and agricultural certification. Policy and Society, 35(1), 71-89.

Gillespie, P. (2012). Participation and power in Indonesian oil palm plantations. Asia Pacific Viewpoint, 53(3), 254-271.

Giovannucci, D. \& Koekoek, F.J. (2003). The state of sustainable coffee: A study of twelve major markets. Conducted for the International Coffee Organization (ICO), United Nations Conference on Trade and Development (UNCTAD), and International Institute for Sustainable Development (IISD).

Giovannucci, D. \& Ponte, S. (2005). Standards as a new form of social contract? Sustainability initiatives in the coffee industry. Food Policy 30(3): 284-301. doi:10.1016/j.foodpol.2005.05.007

Giovannucci, D., Von Hagen, O., \& Wozniak, J. (2013). Corporate Social Responsibility and the role of voluntary sustainability standards. In Schmitz-Hoffmann C, et al. Eds., Voluntary Standards Systems - A Contribution to Sustainable Development, Springer Publishing: Berlin.

Glasbergen, P. (2010). Global Action networks: Agents for collective action, Global Environmental Change, 20, $130-141$.

Glasbergen, P. (2011). Mechanisms of private meta-governance. An analysis of global private governance for sustainable development. International Journal of Strategic Business Alliances, 2(3), 189-206.

Glasbergen, P. (2011). Understanding partnerships for sustainable development analytically: the ladder of partnership activity as a methodological tool. Environmental Policy and Governance 21(1): 1-13.

Glasbergen, P. (2013). Legitimation of Certifying Partnerships in the Global Market Place. Environmental Policy and Governance, 23(6), 354-367, doi:10.1002/eet.1625.

Glasbergen, P., \& Miranda, M. (2003). The sustainability treaty between the Netherlands and Costa Rica: a new perspective on environmental and development cooperation. Sustainable Development, 11(1), 1-16. 
Glasbergen, P. \& Schouten, G. (2015). Transformative capacities of global private sustainability standards: A reflection on scenarios in the field of agricultural commodities. The Journal of Corporate Citizenship, 58, 85-101.

Gray, B. (2007). The process of partnership construction: anticipating obstacles and enhancing the likelihood of successful partnerships for sustainable development. In: Partnerships, governance and sustainable development. Reflections on theory and practice, edited by P. Glasbergen, F. Biermann and A.P.J. Mol. Edward Elgar, pp. 29-48.

Gulbrandsen, L. H. (2012). Dynamic governance interactions: Evolutionary effects of state responses to nonstate certification programs. Regulation \& Governance, 8(1), 74-92.

Ha, T.T.T., Bush, S.R., Mol, A.P.J., \& Dijk, H. van. (2012). Organic coasts? Regulatory challenges of certfying integrated shrimp-mangrove production systems in Vietnam. Journal of Rural Studies, 28(4), 631-639.

Hatanaka, M. (2010). Certification, Partnership, and Morality in an Organic Shrimp Network: Rethinking Transnational Alternative Agrifood Networks. World Development, 38(5), 706-716.

Haug, R. (1999). Some leading issues in international agricultural extension, a literature review. The Journal of Agricultural Education and Extension, 5(4), 263-274. doi:10.1080/13892249985300061

Heckman, J. (2006). A history of organic farming: Transitions from Sir Albert Howard's War in the Soil to USDA National Organic Program. Renewable Agriculture and Food Systems, 21(3), 143-150. doi:10.1079/RAF2005126

Henderson, J., Dicken, P., Hess, M., Coe, N., \&. Yeung, HWC. (2002). Global production networks and the analysis of economic development. Review of International Political Economy 9(3): 436-464. doi:10.1080/09692290210150842

Henry, A. D., \& Vollan, B. (2014). Networks and the challenge of sustainable development. Annual Review of Environment and Resources, 39, 583-610.

Henson, S., \& Humphrey, J. (2010). Understanding the complexities of private standards in global agri-food chains as they impact developing countries. The journal of development studies, 46(9), 1628-1646.

Hermans, F., Kok, K., Beers, P. J., \& Veldkamp, T. (2012). Assessing Sustainability Perspectives in Rural Innovation Projects Using Q-Methodology. Sociologia ruralis, 52(1), 70-91.

Hidayat, N.K., Glasbergen, P., \& Offermans, A. (2015). Sustainability certification and palm oil smallholders' livelihood: A comparison between scheme smallholders and independent smallholders in Indonesia. International Food and Agribusiness Management (IFAMA) Review, 18(3), 25-48.

Hidayat, N. K., Offermans, A., \& Glasbergen, P. (2017). Sustainable palm oil as a public responsibility? On the governance capacity of Indonesian standard for sustainable palm oil (ISPO). Agriculture and Human Values. doi: 10.1007/s10460-017-9816-6

Hoebink, P., Ruben, R., Elbers, W., \& van Rijsbergen, B. (2014). The impact of coffee certification on smallholder farmers in Kenya, Uganda, and Ethiopia.

Hoffmann, U. (2016). Business-as-usual is insufficient against the scale of required fundamental changes. In: UNFSS Report: Meeting sustainability goals voluntary sustainability standards and the role of the government. United Nations.

Hospes, O. (2014). Marking the success or end of global multi-stakeholder governance? The rise of national sustainability standards in Indonesia and Brazil for palm oil and soy. Agriculture and Human Values, 31(3), 425-437.

Hospes, O., \& Kentin, A. (2012). Sustainability governance and scale framing: the case of palm oil. Chapter presented at the The 19th annual conference on multi-organisational partnerships, alliances and network, Wageningen University.

Hunt, W., Birch, C., Vanclay, F., \& Coutts, J. (2014). Recommendations arising from an analysis of changes to the Australian agrocultural research, development and extension system. Food Policy, 44, 129-141.

Huxham, C. \& Vangen, S. (2000). Leadership in the shaping and implementation of collaborative agendas: How things happen in a (not quite) joined-up world. The Academy of Management Journal 43(6): 1159-1175.

Ibanez, M. \& Blackman, A. (2016). Is eco-certification a win-win for developing country agriculture? Organic coffee certification in Colombia. World Development 82: 14-27. Doi: 10.1016/j.worlddev.201601.004. 
Ibnu, M., Glasbergen, P., Offermans, A., \& Arifin, B. (2015). Farmer preferences for coffee certification: A conjoint analysis of the Indonesian smallholders. Journal of Agricultural Science, 7(6), 20-35.

ICCO (2015). Production of cocoa beans 2012-2014. The International Cocoa Organization.

ICOI (2014). April trade statistics. International Coffee Organization. (ICO). Retrieved from http://www.ico.org/trade_statistics.asp?section=Statistics.

ICO (2016). Production of coffee 2011-2016. The International Coffee Organization.

IDH (2013). Cost-benefit analysis of farmer field schools and certification for smallholder tea farmers in Kenya. The Sustainable Trade Initiative.

ISPO (2013). About ISPO. Indonesian Sustainable Palm Oil (ISPO). Retrieved from http://www.ispo-org.or.id/

ITC (2011). The interplay of public and private standards: Literature review series on the impacts of private standards (Vol. Part III). Geneva: International Trade Centre (ITC).

Kalfagianni, A., \& Pattberg, P. (2013a). Global fisheries governance beyond the State: Unraveling the effectiveness of the Marine Stewardship Council. Journal of Environmental Studies and Sciences, 3(2), 184-193.

Kalfagianni, A., \& Pattberg, P. (2013b). Fishing in muddy waters: Exploring the conditions for effective governance of fisheries and aquaculture. Marine Policy, 38, 124-132.

Karns, M. P., \& Mingst, K. A. (2010). International organizations: The politic and process of global governance (2nd ed.). USA: Lynne Rienner.

Klapwijk, C. J., van Wijk, M. T., Rosenstock, T. S., van Asten, P. J. A., Thornton, P. K., \& Giller, K. E. (2014). Analysis of trade-offs in agricultural systems: current status and way forward, Current Opinion in Environmental Sustainability, 6, 110-115.

Klein, E-H, Edelenbos, J., \& Steyn, B. (2010). Trust in governance networks; its impacts on outcomes. Administration and Society, 42(2): 192-221.

Kolk, A. (2011). Mainstreaming sustainable coffee. Sustainable Development. 21(5), 324-337.

Kolk, A. (2012). Towards a sustainable coffee market: paradoxes faced by a multinational company. Corporate Social Responsibility and Environmental Management, 19(2), 79-89.

KPMG, Advisory N.V. (2012). Certification and biodiversity: Exploring improvements in the effectiveness of certification schemes on biodiversity Climate change and sustainability services. The Netherlands.

KPMG, Advisory N. V. (2013). Moving the bars: Sustainability brought to the forefront in the cocoa chain. KPMG Evaluation of the 2008-2012 Cocoa Improvement Program. The Netherlands: KPMG, IDH, Solidaridad and UTZ Certified.

Kristjanson, P., Reid, R. S., Dickson, N., Clark, W. C., Romney, D., Puskur, R., . . Grace, D. (2009). Linking international agricultural research knowledge with action for sustainable development. Proceedings of the National Academy of Sciences, 106(13), 5047-5052.

Kuepper, G. (2010). A brief overview of the history and philosophy of organic agriculture. Kerr Center for Sustainable Agriculture, Poteau, OK: USA.

Kusumadewi, R. (2008). Trade liberalization and Indonesian agricultural products: The importance of special products and special safeguard mechanism. Dissertation: Institute of Social Studies. The Hague, The Netherlands.

Lauzon, A. (2013). From agricultural extension to capacity development: exploring the foundations of an emergent form of practice. International journal of lifelong education, 32(2), 247-266.

Lestari, D. (2010). Palm oil entrepreneurs criticized the role of RSPO. Retrieved from http://www.bumn.go.id/ptpn4/berita/642/Pebisnis.Sawit.Gugat.Peran.RSPO

Li, T. M. (2002). Local histories, global markets: Cocoa and class in upland Sulawesi. Development and Change, 33(3), 415-437.

Lindblad, J. T. e. (1996). Historical foundations of a national economy in Indonesia, 1890s-1990s. Amsterdam [etc.]: North-Holland.

Loconto, A. (2016). The role of knowledge in transitions to sustainable food systems: examples from institutional innovations. Knowledge and Information for Sustainable Food Systems, 203.

Luttikholt, L. W. M. (2007). Principles of organic agriculture as formulated by the International Federation of Organic Agriculture Movements (IFOAM). NJAS - Wageningen Journal of Life Sciences, 54, 347-360. 
Mallet, P., Maireles, M., Kennedy, E., \& Devisscher, M. (2016). ISEAL Report: How sustainability standards can contribute to landscape approaches and zero deforestation commitments. London: ISEAL Alliance.

Mandolesi, S., Nicholas, P., Naspetti, S., \& Zanoli, R. (2015). Identifying perspectives on innovation in low-input and organic dairy supply chains: A Q-methodological study. Food Policy, 54, 25-34.

Mangnus, E., \& Bitzer, V. (2015). Extension in motion. KIT Working Paper 2015:4.

Manning, S., Boons, F., Von Hagen, O., \& Reinecke, J. (2012). National contexts matter: The co-evolution of sustainability standards in global value chains. Ecological Economics, 83, 197-209.

Manning, S., \& Von Hagen, O. (2010). Linking local experiments to global standards: How project networks promote global institution-building. Scandinavian Journal of Management, 26(4), 398-416.

Marin-Burgos, V., Clancy, J.S., \& Lovett, J.C. (2015). Contesting legitimacy of voluntary sustainability certification schemes: Valuation languages and power asymmetries in the Roundtable of Sustainable Palm Oil in Colombia. Ecological Economics 117: 303-313.

Marliati, Sumardjo, Asngari, P. S., Tjitropranoto, P., \& Saefuddin, A. (2008). Faktor-faktor penentu peningkatan kinerja penyuluh pertanian dalam memberdayakan petani (Kasus di Kabupaten Kampar Provinsi Riau). Jurnal Penyuluhan, 4(2), 92-99.

Martinez, M. G., \& Poole, N. (2004). The development of private fresh produce safety standards: implications for developing Mediterranean exporting countries. Food Policy, 29(3), 229-255.

Marx, A., Maertens, M., Swinnen, J., \& Wouters, J. (Eds.). (2012). Private standards and global governance. UK: Edward Elgar.

Matzdorf, B. \& Müller, K. (2010). Environmental economic and social trade-offs, International Conference and Workshop Salzau Castle and Kiel University.

Mawardi, S. (2009a). Advantages, constraints and key success factors in establishing origin-and tradition-linked quality signs: the case of Kintamani Bali Arabica coffee geographical indication, Indonesia Case study on quality products linked to geographical origin in Asia carried out for FAO, Indonesian Coffee and Cocoa Research Institute. Retrieved from http://www.fao.org/fileadmin/templates/olq/documents/documents/ Kintamani.pdf

Mawardi, S. (2009b). Establihment of geographical indication protection system in Indonesia, case in coffee. Chapter presented at the Worlwide Symposium on Geographical Indications Sofia, 10-12 June 2009.

Mawardi, S., Ismayadi, C., Wibawa, A., Sulistyowati, \& Yusianto. (2006). Model kemitraan bermediasi (Motramed) untuk pengembangan agribisnis kopi melalui perbaikan mutu dan sistem pemasaran di tingkat kelompok tani. Prosiding coffee symposium, p.78-99.

Mayer, F., \& Gereffi, G. (2010). Regulation and Economic Globalization: Prospects and Limits of Private Governance. Business and Politics, 12(3), chapter11.

Mayne, J., \& Johnson, N. (2015). Using theories of change in the CGIAR Research Program on Agriculture for Nutrition and Health. Evaluation, 21(4), 407-428.

McCarthy, J.F., Gillespie, P., \& Zen, Z. (2012). Swimming upstream: Local Indonesian production networks in "Globalized" palm oil production. World Development, 40(3), 555-569.

McCarthy, J.F. (2010). Processes of inclusion and adverse incorporation: oil palm and agrarian change in Sumatra, Indonesia. The Journal of Peasant Studies, 37(4), 821-850.

McMillan, J. (2011). What happens when the university meets the community? Service learning, boundary work and boundary workers. Teaching in Higher Education, 16(5), 553-564.

Meadowcroft, J. (2007). Who is in charge here? Governance for sustainable development in a complex world. Journal of Environmental Policy and Planning, 9: 299-314.

Media Perkebunan. (2013, March 25). Standardization as a proof of identity. Retrieved from http://mediaperkebunan.net/index.php?option=com_content\&view=chapter\&id=421:standarisasi-buktijatidiri\&catid=17: berita.

Ministry of Agriculture. (2013). Palm oil exports per destination country. Data center and agricultural information system. Retrieved from http://aplikasi.deptan.go.id/eksim2012/hasileksporKomoditi.asp

Ministry of Agriculture. (2014). Cocoa plantation area, production an productivity in Indonesia 2010-2014. http://aplikasi.pertanian.go.id/bdsp/hasil_lok.asp. Assessed 25 April 2015. 
Moriarty, K., Elchinger, M., Hill, G., Katz, J., \& Barnett, J. (2014). Cacao intensification in Sulawesi: A green prosperity model project. Colorado: National Renewable Energy Laboratory. http://www.nrel.gov/docs/ fy140sti/62434.pdf. Accessed 21 July 2015.

Moses, J., \& Knutsen, T. (2012). Ways of knowing: Competing methodologies in social and political research: Palgrave Macmillan.

Mundy, P. (1992). Information sources of agricultural extension specialists in Indonesia. (PhD PhD thesis), University of Wisconsin-Madison. Retrieved from http://www.mamud.com/Docs/dissertation_paulmundy.pdf

Neilson, J. (2007). Global markets, farmers and the State: Sustaining profits in the Indonesian cocoa sector. Bulletin of Indonesian Economic Studies, 43(2), 227-250.

Neilson, J. (2008). Global Private Regulation and Value-Chain Restructuring in Indonesian Smallholder Coffee Systems. World Development, 36(9), 1607-1622.

Nur Aini, F., \& Soetanto, A. (2013). Cocoa sustainability certification in Indonesia. Indonesian Coffee and Cocoa Research Institute (ICCRI).

OECD. (2012). OECD Review of Agricultural Policies: Indonesia 2012: OECD Publishing.

Offermans, A. (2012). The perspectives method: Towards socially robust river management. Ph.D. Thesis: Maastricht University, the Netherlands.

Offermans, A. \& Glasbergen, P. (forthcoming 2017 in Development and Practice).

Oosterveer, P. (2014). Promoting sustainable palm oil: Veiwed from a global networks and flows perspective. Journal of Cleaner Production, 107, 146-153.

Overdevest C., Zeilin, J. (2014). Assembling an experimentalist regime: Transnational governance interactions in the forest sector. Regulation \& Governance 8, 22-48.

Pajaro, M.G., Mulrennan, M.E., \& Vincent, A.C.J. (2010). Toward an integrated marine protected areas policy: connecting the global to the local. Environment, Development, and Sustainability, 12, 945-965, doi: 10.1007/s10668-010-9233-0

Palmujoki, E. (2006). Public-private governance patterns and environmental sustainability. Environment, Development and Sustainability, 8, 1-17, doi: 10.1007/s10668-004-6145-x

Pattberg, P. (2006). Private Governance and the South: Lessons from Global Forest Politics. Third World Quarterly, 27(4), 579-593.

PBL Netherlands Environmental Assessment Agency. (2010). Roles of governments in multi-actor sustainable supply chain governance systems and the effectiveness of their interventions: An exploratory study. Universiteit Utrecht: the Netherlands.

Perez-Aleman, P., \& Sandilands, M. (2008). Building value at the top and the bottom of the global supply chain: MNC-NGO partnerships. California management review, 51(1), 24-49.

Pesqueira, L., \& Glasbergen, P. (2013). Playing the politics of scale: Oxfam's intervention in the Roundtable on Sustainable Palm Oil. Geoforum, 45, 296-304.

Pichler, M. (2013). "People, Planet \& Profit": Consumer-oriented hegemony and power relations in palm oil and agrofuel certification. Journal of Environment \& Development, 22(4), 370-390.

Ponte, S. (2008). Greener than thou: The political economy of fish ecolabelling and its local manifestations in South Africa. World development, 36(1). 159-175.

Ponte, S., \& Cheyns, E. (2013), Voluntary standards, expert knowledge and the governance of sustainability networks. Global Networks, 13: 459-477.

Potts, J., Lynch, M., Wilkings, A., Huppé, G., Cunningham, M., \& Voora, V. (2014). The state of sustainability initiatives review 2014: Standards and the green economy. International Institute for Sustainable Development (IISD) and the International Institute for Environment and Development (IIED), 332.

Previte, J., Pini, B., \& Haslam-McKenzie, F. (2007). Q methodology and rural research. Sociologia ruralis, 47(2), 135-147.

Rainforest Alliance. (2016, December). Our history: Highlights from 30 years of conservation. Retrieved from http://www.rainforest-alliance.org/about

Reinecke, J., Manning, S., von Hagen, O. (2012). The emergence of a standards market: Multiplicity of sustainability standards in the global coffee industry. Organization Studies, 33(5-6), 791-814.

Rivera, W. M. (2011). Public Sector Agricultural Extension System Reform and the Challenges Ahead. The Journal of Agricultural Education and Extension, 17(2), 165-180. doi:10.1080/1389224X.2011.544457 
Robinson, J. (2004). Squaring the Circle? Some thoughts on the idea of sustainable development. Ecological Economics, 48:369-384.

Ros-tonen, M. A., Van Leynseele, Y-P. B., Laven, A., \& Sunderland, T. (2015). Landscapes of social inclusion: Inclusive value-chain collaboration through the lenses of food sovereignty and landscape governance. The European Journal of Development Research, 27, 523-540.

RSPO. (2007). RSPO-principles and criteria for sustainable palm pil production. Retrieved from the Roundtable on Sustainable Palm Oil website http://www.rspo.org/files/resource

RSPO. (2008). National interpretation of RSPO principles and criteria for sustainable palm oil production, Republic of Indonesia. Retrieved from http://www.rspo.org/file/PDF/RSPO_national\%20interpretation/ ghana/indonesia/NI_INANIWG_Final_English_May2008_ver01.pdf.

Ruben, R., \& Fort, R. (2012). The impact of fair trade certification for coffee farmers in Peru. World Development, 40(3), 570-582.

Saad, M., Rowe, K., \& James, P. (1999). Developing and sustaining effective partnerships through a high level of trust. In: Public and private sector partnetships: Furthering development, edited by L. Montanheiro et al. SHU Press, Sheffield.

Sahide, M.A., Nurrochmat, D.R., Giessen, L. (2015). The regime complex for tropical rainforest transformation: Analysing the relevance of multiple global and regional land use regimes in Indonesia. Land Use Policy, 47, 408-425.

Saleh, A. (2012). Motivasi Petani dalam Menerapkan Teknologi Produksi Kakao: Kasus Kecamatan Sirenja, Sulawesi Tengah. Pelita Perkebunan, 26(1), 42-56.

Sawit Watch. (2013). Petition of guarantee fairness, transparency and balance in the RSPO grievance mechanism. Retrieved from http://sawitwatch.or.id/2013/11/1445/.

Sawyer, E. N., Kerr, W. A., \& Hobbs, J. E. (2008). Consumer preferences and the international harmonization of organic standards. Food Policy, 33(6), 607-615.

Sayer, J., Margules, C., Boedhihartono, A. K., . . ., \& Saryanthi, R. (2014) Landscape approaches; what are the pre-conditions for success? Sustainability Science. DOI: 10.1007/s11625-014-0281-5

Schouten, G, \& Bitzer, V. (2015). The emergence of Southern standards in agricultural value chains: A new trend in sustainability governance? Ecological Economics, 120, 175-184.

Schouten, G., \& Glasbergen, P. (2011). Creating legitimacy in global private governance: The case of the Roundtable on Sustainable Palm Oil. Ecological Economics, 70(11), 1891-1899.

Schouten, G., Leroy, P., \& Glasbergen, P. (2012). On the deliberative capacity of private multi-stakeholder governance: The roundtables on responsible soy and sustainable palm oil. Ecological Economics, 83, 4250.

Schouten, G., Vellema, S., \& Van Wijk, J. (2016). Diffusion of global sustainability standards: The institutional fit of the ASC-shrimp standards in Indonesia. Rev. adm. Empres. 56(4): 411-423.

Schruijer, S.G. (1999). Leadership and organizational change: An introduction. European Journal of Work and Organizational Psychology 8(1): 1-8.

Schuler, D.A., \& Christmann, P. (2011). The effectiveness of market-based social governance schemes: The case of fair trade coffee. Business Ethics Quarterly 21(1): 133-156.

Schwartz-Shea, P. \& Yanow, D. (2012). Interpretative Research Design. Concepts and Processes. New York and London: Routledge.

Shapiro, H.-Y., \& E. M. Rosenquist. (2004). Public/Private Partnerships in Agroforestry: The Example of Working Together to Improve Cocoa Sustainability. Agroforestry Systems, 61: 453-462.

Smith, T. M., \& Fischlein, M. (2010). Rival private governance networks: Competing to define the rules of sustainability performance. Global Environmental Change, 20(3), 511-522.

Soemarmo, D., Mawardi, S., Maspur \& Prayuginingsih, H. (2009). Peningkatan nilai tambah pengolahan kopi Arabika metode basah menggunakan model kemitraan bermediasi (Motramed) pada unit pengolahan hasil di Kabupaten Ngada - NTT. Pelita Perkebunan, 25(2), 38-55.

Steering Committee of the State-of-Knowledge Assessment of Standards and Certification. (2012). Towards sustainability: The roles and limitations of certification. Washington, D.C.: Resolve, Inc. 
Stein, D. \& Valters, C. (2012). Understanding Theory of Change in International Development. JSRP Chapter 1. ISSN 2051-0926.

Subagyo. (2014, March 20). ISPO certified palm land reaches 378 thousand hectares., Antaranews. Retrieved from http://www.antaranews.com/berita/425158/lahan-sawit-tersertifikasi-ispo-378-ribu-ha.

Sudarsono. (2014, Maret 3). Palm oil companies will get the incentive, Sindonews. Retrieved from http://ekbis.sindonews.com/read/840614/34/perusahaan-sawit-akan-dapat-insentif-1393818001.

Suharto, R. (2010, December 2). Indonesia needs ISPO, The Jakarta Post. Retrieved from http://www.thejakartapost.com/news/2010/12/02/why-indonesia-needs-ispo.html

Suryatin, E., \& Beatrice (2013). Inside story from an Indonesian cocoa farmer organization: Lessons learned from collective marketing for the cocoa sector Amanah cooperative, Polewali Mandar, West Sulawesi. In I. Suharto, \& P. V. I. Agustiyanto (Eds.). Indonesia: VECO Indonesia.

Susanto, F. X. (1994). Tanaman Kakao Budidaya dan Pengolahan Hasil. Jakarta, Indonesia: Kanisius.

Swisscontact. (2012). Sustainable cocoa production program. Annual report. http://www.swisscontact.org/ fileadmin/images/Country_Subpages/Indonesia/publications/SCPP_Annual_Report_2012.pdf. Accessed 10 September 2014.

Swissconcact. (2013). Sustainable cocoa production program Indonesia. Annual report. http://www.swisscontact.org/fileadmin/images/Country_Subpages/Indonesia/publications/SCPP_Annual _Report_2013.pdf. Accessed 21 October 2014.

Swisscontact. (2014). Sustainable cocoa production program Indonesia. Annual Report. http://www.swisscontact.org/fileadmin/images/Country_Subpages/Indonesia/SCPP_Biannual_Report_09 _2014.pdf. Accessed 15 February 2015.

Swisscontat. (2015). Sustainable cocoa production program Indonesia. Annual Report. http://www.swisscontact.org/fileadmin/images/Country_Subpages/Indonesia/publications/Brochure_SC PP_2015-ENG.pdf. Accessed 1 June 2016.

Tallontire, A., Opondo, M., Nelson, V., \& Martin, A. (2011). Beyond the vertical? Using value chains and governance as a framework to analyse private standards initiatives in agri-food chains. Agriculture and Human Values, 28(3), 427-441.

Tisenkopfs, T., Kunda, I., šūmane, S., Brunori, G., Klerkx, L., \& Moschitz, H. (2015). Learning and Innovation in Agriculture and Rural Development: The Use of the Concepts of Boundary Work and Boundary Objects. The Journal of Agricultural Education and Extension, 21(1), 13-33. doi:10.1080/1389224x.2014.991115

Todaro, M.P., \& Smith, S.C. (2003). Economic Development (8th ed.). UK: Pearson Education Limited.

TSPN, Trade Standards Practitioners Network. (2011). Food-related voluntary sustainability standards: A strategy guide for policy makers. Draft for discussion. www.tradestandards.org.

UNDANG UNDANG REPUBLIK INDONESIA 16/2006 TENTANGSISTEM PENYULUHAN PERTANIAN, PERIKANAN, DAN KEHUTANAN [law 16/2006 on extension for agriculture, fisheries and forestry], (2006).

UNFSS. (2016). Meeting sustainability goals: Voluntary sustainability standards and the role of the government. $2^{\text {nd }}$ Flagship report of the United Nations Forum on Sustainability Standards (UNFSS).

UNDP. (2013, November 1). ISPO and RSPO enter into strategic co-operation. Press release. Retrieved from http://www.id.undp.org/content/indonesia/en/home/presscenter/press releases/2013/11/01/ispo-andrspo-enter-into-strategic-co-operation-/.

Vaast, P., \& Somarriba, E. (2014). Trade-offs between crop intensification and ecosystem services: the role of agroforestry in cocoa cultivation. Agroforest Systems, 88, 947-956.

van de Fliert, E. (2015). Assessing the impact of rural advisory services on smallholders' sustainable farm management. CAPSA Palawija Newsletter, 32(1).

Van der Geest, P., \& Unno, A. (2012). A new extraterritoriality? Aquaculture certification, sovereignty, and empire. Political Geography, 31(6), 358-367.

Van Dijk, M. P., \& Trienekens, J. (2012). Global value chains: Linking local producers from developing countries to international markets. Amsterdam University Press. 
Van Rijsbergen, B., Elbers, W., Ruben, R., \& Njuguna, S.N. (2016). The Ambivalent Impact of Coffee Certification on Farmers' Welfare: A Matched Panel Approach for Cooperatives in Central Kenya. World Development, 77: 277-292. http://dx.doi.org/10.1016/j.worlddev.2015.08.021.

Van Tulder, R. \& Pfisterer, S. (2013). Creating Partnering Space. Social Partnerships and Responsible Business: A Research Handbook, 105.

VECO Indonesia (April 2014). Koperasi tani Masagena: Agar petani berjaya. In LONTAR quartely newsletter. Accessed 7 Februari 2015

Vellema, S., Ton, G., de Roo, N., \& van Wijk, J. (2013). Value chains, partnerships and development: Using case studies to refine programme theories. Evaluation, 19(3), 304-320.

Vellema, S., \& van Wijk, J. (2015). Partnerships intervening in global food chains: the emergence of co-creation in standard-setting and certification. Journal of Cleaner Production, 107, 105-113.

Vellema, W., Buritica Casanova, A., Gonzalez, C., \& D'Haese, M. (2015). The effect of specialty coffee certification on household livelihood strategies and specialization. Food Policy, 57, 13-25. doi:https://doi.org/10.1016/j.foodpol.2015.07.003

Verburg, J. (2014). Based on the Oxfam Discussion paper "Fair company - community partnership in palm oil development" by AidEnvironment. UK: Oxfam International.

Vermeulen, W. J. V., \& Kok, M. T. J. (2012). Government interventions in sustainable supply chain governance: Experience in Dutch front-running cases. Ecological Economics, 83, 183-196.

Virgiano, L. (2012). Development communication in agriculture: A retrospective study of Motramed (in English: Mediated Partnership Model) program for Arabica coffee farmers in Bondowoso, Indonesia. Thesis: Malmo University.

Visseren-Hamakers, I. J., Arts, B., \& Glasbergen, P. (2007). Partnership as a governance mechanism in development cooperation: Intersectoral North-South partnerships for marine biodiversity: Edward Elgar: Northampton, MA.

Visseren-Hamakers, I. J., \& Glasbergen, P. (2007). Partnerships in forest governance. Global Environmental Change, 17(3-4), 408-419. doi:10.1016/j.gloenvcha.2006.11.003

von Geibler, J. (2013). Market-based governance for sustainability in value chains: conditions for successful standard setting in the palm oil sector. Journal of Cleaner Production, 56, 39-53. doi: https://doi.org/10.1016/j.jclepro.2012.08.027

Vogel, I. (2012). Review of the use of "theory of change" in international development. United Kingdom: commissioned by the UK Department for International Development (DFID).

Waddock, S. A. (1989). Understanding social partnerships: An evolutionary model of partnership organizations. Administration \& Society, 21(1), 78-100.

Wahyudi, T., \& Jati, M. (2012). Challenges of sustainable coffee certification in Indonesia Chapter presented at the Seminar on the Economic, Social and Environmental Impact of Certification on the Coffee Supply Chain: International Coffee Council 109th Session, London, UK. Retrieved from http://www.ico.org/ event_pdfs/seminar-certification/certification-iccri-chapter.pdf.

Watts, S., \& Stenner, P. (2005). Doing Q methodology: theory, method and perspective. Qualitative research in psychology, 2(1), 67-91.

Wenger, E. (1998). Communities of practice: Learning, meaning and identity. Cambridge: Cambridge University Press.

Wijaya, A., \& Glasbergen, P. (2016). Towards a new scenario in agricultural sustainability certification? The response of the Indonesian national government to private certification. Journal of Environment and Development, 25(2), 219-246, doi: 10.1177/1070496516640857.

World Bank. (2007). Agricultural Extension Services in Indonesia: new approaches and emerging issues (38468). Retrieved from Washington D.C.: http://www-wds.worldbank.org/external/default/WDSContentServer/ WDSP/IB/2010/03/23/000333038_20100323010352/Rendered/PDF/384680ESWOWhit10Box345622B01 PUBLIC1.pdf

World Growth. (2011). The economic benefit of palm oil to Indonesia. Arlington, VA: World Growth.

Wright, P. N. (2013). Is Q for you?: using Q methodology within geographical and pedagogical research. Journal of Geography in Higher Education, 37(2), 152-163. 


\section{REFERENCES}

Yanow, D. \& Schwartz-Shea, P. Eds. (2014). Interpretation and Method. Empirical research methods and the interpretative turn. Armonk: M.E. Sharpe.

Yanuardy, D. (2014). The Business of world cocoa beans and smallholders in Central Sulawesi. Bogor, Indonesia: Sajogyo Institute.

Zadek, S. (2010). Emerging Nations and Sustainability. Chimera or Leadership. Notizie di POLITEIA, XXVI, 89. ISSN 1128-2401, pp. 153-167.

Zanden, J. L. v., \& Marks, D. (2012). An economic history of Indonesia 1800-2010. London: Routledge. 


\section{Appendix A}

The price history of Bali coffee compared with the world coffee price

\begin{tabular}{ccccc}
\hline Year & $\begin{array}{c}\text { World Coffee Price } \\
\text { (USD/kg) }\end{array}$ & $\begin{array}{c}\text { World coffee price } \\
(\text { IDR)** }\end{array}$ & $\begin{array}{c}\text { Bali coffee price at } \\
\text { farmer gate (IDR)*** }\end{array}$ & $\begin{array}{c}\text { Discounted/ } \\
\text { premium to } \\
\text { world price }\end{array}$ \\
\hline 2001 & 1.37 & $14,095.02$ & 5,200 & $-63.1 \%$ \\
2002 & 1.36 & $12,560.65$ & 12,000 & $-4.5 \%$ \\
2003 & 1.42 & $12,131.23$ & 12,000 & $-1.1 \%$ \\
2004 & 1.77 & $15,940.51$ & 14,800 & $-7.2 \%$ \\
2005 & 2.53 & $24,690.45$ & 24,500 & $-0.8 \%$ \\
2006 & 2.52 & $23,054.80$ & 24,806 & $7.6 \%$ \\
2007 & 2.72 & $24,959.85$ & 23,671 & $-5.2 \%$ \\
2008 & 3.08 & $30,066.30$ & 28,600 & $-4.9 \%$ \\
2009 & 3.17 & $32,840.42$ & 27,400 & $-16.6 \%$ \\
2010 & 4.32 & $39,219.26$ & 28,083 & $-28.4 \%$ \\
2011 & 5.98 & $52,429.02$ & 36,375 & $-30.6 \%$ \\
2012 & 4.11 & $38,719.01$ & 37,871 & $-2.2 \%$ \\
2013 & 3.08 & $32,491.60$ & 38,854 & $19.6 \%$ \\
2014 & 4.42 & $52,503.32$ & 53,833 & $2.5 \%$ \\
2015 & 3.53 & $47,451.93$ & 56,833 & $19.8 \%$ \\
\hline
\end{tabular}

Source: The Provincial Estate Crops Agency of Bali (Disbun Bali), 2015 and Mawardi et al., 2006.

Notes:

* Annual average price for other milds Arabica (ICO data 2016). Other Milds is a one of group indicator prices made by International Coffee Organization (ICO) next to other groups: Columbian Milds, Brazilian Naturals and Robustas. Arabica coffee from Indonesia is part of Other Milds group.

** Conversion to IDR based on annual average rate issued by Bank Indonesia (Central Bank, 2016).

*** Unsorted coffee contains about $13 \%$ moisture. 


\section{Appendix B}

Table of rotated factor loadings for 64 respondents in three districts

\begin{tabular}{|c|c|c|c|}
\hline No Q sort & ID Q sort & F1 & F2 \\
\hline 1 & E01-Lut & 0.2630 & $0.6738 *$ \\
\hline 2 & E02-Lut & $0.5501^{*}$ & 0.2242 \\
\hline 3 & E03-Lut & $0.6176^{*}$ & 0.0257 \\
\hline 4 & E04-Lut & $0.5094 *$ & 0.2747 \\
\hline 5 & E05-Lut & $0.6489 *$ & 0.2138 \\
\hline 6 & E06-Lut & $0.4311^{*}$ & 0.3108 \\
\hline 7 & E07-Lut & 0.4157 & $0.4694 *$ \\
\hline 8 & E08-Lut & 0.0323 & $0.5199 *$ \\
\hline 9 & E09-Lut & 0.2528 & $0.4783^{*}$ \\
\hline 10 & E10-Lut & $0.5041^{*}$ & 0.2720 \\
\hline 11 & E11-Lut & 0.2698 & $0.3331^{*}$ \\
\hline 12 & E12-Lut & $0.4025^{*}$ & 0.1380 \\
\hline 13 & F01-Lut & $0.6652^{*}$ & 0.1838 \\
\hline 14 & F02-Lut & $0.4632^{*}$ & -0.1631 \\
\hline 15 & F03-Lut & $0.4471^{*}$ & 0.3182 \\
\hline 16 & F04-Lut & $0.6068^{*}$ & 0.2875 \\
\hline 17 & F05-Lut & $0.3870 *$ & 0.2218 \\
\hline 18 & F06-Lut & $0.5567^{*}$ & 0.4632 \\
\hline 19 & F07-Lut & 0.2032 & $0.5602 *$ \\
\hline 20 & F08-Lut & $0.6252^{*}$ & 0.0747 \\
\hline 21 & F09-Lut & 0.2032 & $0.5602 *$ \\
\hline 22 & F10-Lut & 0.1831 & $0.4326^{*}$ \\
\hline 23 & F11-Lut & 0.0147 & $0.5702^{*}$ \\
\hline 24 & F12-Lut & $0.5045^{*}$ & 0.0140 \\
\hline 25 & F13-Lut & $0.3557^{*}$ & -0.0813 \\
\hline 26 & E01-Bon & 0.2737 & $0.7077^{*}$ \\
\hline 27 & E02-Bon & -0.3616 & $0.6848 *$ \\
\hline 28 & E03-Bon & 0.0468 & 0.0632 \\
\hline 29 & E04-Bon & 0.0936 & $0.7907^{*}$ \\
\hline 30 & E05-Bon & -0.0001 & $0.8094 *$ \\
\hline 31 & E06-Bon & 0.1044 & $0.6485^{*}$ \\
\hline 32 & E07-Bon & 0.3091 & $0.4344^{*}$ \\
\hline 33 & E08-Bon & 0.3112 & 0.1593 \\
\hline 34 & E09-Bon & $0.4080^{*}$ & 0.3917 \\
\hline 35 & E10-Bon & -0.0880 & $0.6188^{*}$ \\
\hline 36 & E11-Bon & 0.0384 & 0.2452 \\
\hline 37 & E12-Bon & -0.0069 & $0.4397^{*}$ \\
\hline 38 & F01-Bon & -0.0066 & $0.3680^{*}$ \\
\hline 39 & F02-Bon & $0.3658^{*}$ & 0.0606 \\
\hline 40 & F03-Bon & $0.3792 *$ & -0.1009 \\
\hline 41 & F04-Bon & $0.7368^{*}$ & -0.0739 \\
\hline 42 & F05-Bon & 0.2508 & 0.1996 \\
\hline 43 & F06-Bon & $0.4610^{*}$ & 0.3309 \\
\hline 44 & F07-Bon & $0.3853^{*}$ & 0.1078 \\
\hline 45 & F08-Bon & $0.4826^{*}$ & 0.1619 \\
\hline 46 & F09-Bon & $0.4469 *$ & 0.4049 \\
\hline 47 & F10-Bon & 0.1356 & $0.4613^{*}$ \\
\hline 48 & F11-Bon & $0.7069 *$ & -0.1792 \\
\hline 49 & F12-Bon & 0.2384 & $0.5022 *$ \\
\hline
\end{tabular}




\begin{tabular}{lccc}
\hline 50 & F13-Bon & -0.1135 & $0.6557^{*}$ \\
51 & E01-Pel & $0.5893^{*}$ & 0.0679 \\
52 & E02-Pel & $0.6683^{*}$ & 0.0042 \\
53 & E03-Pel & 0.3028 & $0.3755^{*}$ \\
54 & E04-Pel & 0.0841 & $0.3378^{*}$ \\
55 & E05-Pel & 0.4723 & $0.5700^{*}$ \\
56 & E06-Pel & $0.4417^{*}$ & 0.2935 \\
57 & E07-Pel & $0.5795^{*}$ & 0.1787 \\
58 & F01-Pel & 0.2878 & $0.4966^{*}$ \\
59 & F02-Pel & $0.6120^{*}$ & 0.2796 \\
60 & F03-Pel & 0.2840 & $0.4417^{*}$ \\
61 & F04-Pel & $0.4852^{*}$ & 0.3637 \\
62 & F05-Pel & $0.6713^{*}$ & 0.1996 \\
63 & F06-Pel & $0.5444^{*}$ & 0.4279 \\
64 & F07-Pel & $0.3754^{*}$ & 0.2556 \\
\hline$\%$ & Expl. Var. & 17 & 16 \\
\hline
\end{tabular}




\section{Appendix C}

Tables of extension workers who are loaded in the same factor as their farmers

Region 1: LUT (North Luwu)

\begin{tabular}{|c|c|c|c|}
\hline $\begin{array}{l}\text { Extension workers Q- } \\
\text { sort ID }\end{array}$ & Extension workers & $\begin{array}{l}\text { Farmers belonging to the } \\
\text { extension worker on the } \\
\text { left }\end{array}$ & Farmers Q-sort ID \\
\hline \multicolumn{4}{|l|}{ Sub-district A: } \\
\hline E01-Lut & $B$ & $A$ & F01-Lut \\
\hline E02-Lut & $A$ & $A$ & F02-Lut \\
\hline E03-Bon & $A$ & - & - \\
\hline E04-Bon & $A$ & - & - \\
\hline E05-Bon & $A$ & - & - \\
\hline E07-Bon & B & - & - \\
\hline \multicolumn{4}{|l|}{ Sub-district B: } \\
\hline \multirow[t]{2}{*}{ E06-Bon } & \multirow[t]{2}{*}{ A } & $A$ & F05-Lut \\
\hline & & $A$ & F06-Lut \\
\hline \multirow[t]{3}{*}{ E08-Bon } & \multirow[t]{3}{*}{ B } & B & F07-Lut \\
\hline & & $A$ & F08-Lut \\
\hline & & $\mathrm{B}$ & F09-Lut \\
\hline \multirow[t]{2}{*}{ E09-Bon } & \multirow[t]{2}{*}{$B$} & $\mathrm{~B}$ & F10-Lut \\
\hline & & B & F11-Lut \\
\hline \multirow[t]{2}{*}{ E10-Bon } & \multirow[t]{2}{*}{$A$} & $A$ & F12-Lut \\
\hline & & $A$ & F13-Lut \\
\hline E11-Bon & $\mathrm{B}$ & - & - \\
\hline \multirow[t]{2}{*}{ E12-Bon } & \multirow[t]{2}{*}{$A$} & $A$ & F03-Lut \\
\hline & & $A$ & F04-Lut \\
\hline
\end{tabular}

Region 2: Bondowoso, East Java

\begin{tabular}{|c|c|c|c|}
\hline $\begin{array}{l}\text { Extension workers Q- } \\
\text { sort ID }\end{array}$ & Extension workers & $\begin{array}{l}\text { Farmers belonging to the } \\
\text { extension worker on the } \\
\text { left }\end{array}$ & Farmers Q-sort ID \\
\hline \multicolumn{4}{|l|}{ Sub-district A: } \\
\hline E01-Bon & $B$ & B & F01-Bon \\
\hline \multirow[t]{2}{*}{ E02-Bon } & \multirow[t]{2}{*}{$B$} & $\mathrm{~A}$ & F02-Bon \\
\hline & & A & F03-Bon \\
\hline \multirow[t]{2}{*}{ E03-Bon } & \multirow[t]{2}{*}{ B } & $A$ & F11-Bon \\
\hline & & $B$ & F12-Bon \\
\hline E04-Bon & B & $B$ & F13-Bon \\
\hline E05-Bon & $B$ & - & - \\
\hline E06-Bon & $B$ & - & - \\
\hline \multicolumn{4}{|l|}{ Sub-district B: } \\
\hline E07-Bon & B & - & - \\
\hline \multirow[t]{2}{*}{ E08-Bon } & \multirow[t]{2}{*}{ A } & A & F04-Bon \\
\hline & & A & F05-Bon \\
\hline E09-Bon & $A$ & $A$ & F06-Bon \\
\hline
\end{tabular}




\begin{tabular}{|l|c|c|l|}
\hline E10-Bon & B & - & - \\
\hline E11-Bon & \multirow{2}{*}{ B } & A & F07-Bon \\
\cline { 3 - 4 } & & A & F08-Bon \\
\hline E12-Bon & \multirow{2}{*}{ B } & A & F09-Bon \\
\cline { 3 - 4 } & & B & F10-Bon \\
\hline
\end{tabular}

Region 3: Pelalawan

\begin{tabular}{|c|c|c|c|}
\hline $\begin{array}{c}\text { Extension workers Q- } \\
\text { sort ID }\end{array}$ & Extension workers & $\begin{array}{c}\text { Farmers belonging to the } \\
\text { extension worker on the } \\
\text { left }\end{array}$ & Farmers Q-sort ID \\
\hline \multicolumn{4}{|l|}{ Sub-district A: } \\
\hline \multirow[t]{2}{*}{ E01-Pel } & \multirow[t]{2}{*}{$A$} & B & F01-Pel \\
\hline & & $A$ & F02-Pel \\
\hline E02-Pel & A & - & - \\
\hline E03-Pel & $B$ & - & - \\
\hline E04-Pel & B & $\mathrm{B}$ & F03-Pel \\
\hline \multicolumn{4}{|l|}{ Sub-district B: } \\
\hline \multirow[t]{2}{*}{ E05-Pel } & \multirow[t]{2}{*}{ B } & A & F04-Pel \\
\hline & & A & F05-Pel \\
\hline E06-Pel & A & A & F06-Pel \\
\hline E07-Pel & $A$ & A & F07-Pel \\
\hline
\end{tabular}





\section{Summary}

\section{Contested sustainability standards in Indonesian agriculture:}

On the process of claiming government authority

Over the last twenty years, we have seen a proliferation of private sustainability standards and certification schemes addressing the production of agricultural commodities in Southern countries. Most of these approaches are developed by Northern-based businesses and nongovernmental organizations (NGOs) or by partnership arrangements between them. In the meantime, a very complex and often confusing system of sustainability standards and certifications has materialized. In this dissertation, we argue that Southern governments, such as Indonesia, need to reconsider their authority in the market system. This process of 'claiming authority' creates many tensions, as it is being realized in a decentralized and fragmented government system through various institutional arrangements. We also observed that in recent years, Southern governments developed public alternatives as a form of reclaiming public authority over private standards and certification schemes.

This dissertation explores how the Indonesian government positions itself in the sustainability contestations and the different ways Indonesia claims its authority in the confrontation with Northern-based private standards and certifications. Therefore, this dissertation aims to answer the following three main questions:

1. How and why is the Indonesian government involved in sustainability contestations in the agricultural production of plantation crops?

2. What challenges do these involvements create for the government and how does the government respond to these challenges?

3. What do these involvements imply for viable forms of government interference in the process of creating a more sustainable agricultural production?

In our research, we particularly focused on the different ways through which the Indonesian government claims its authority in various institutional arrangements. See the table below. 


\begin{tabular}{|c|c|c|c|c|c|}
\hline \multirow[b]{2}{*}{$\begin{array}{l}\text { Institutional } \\
\text { arrangements }\end{array}$} & \multicolumn{2}{|c|}{ Chapter 2} & \multirow{2}{*}{$\begin{array}{c}\text { Chapter } 3 \\
\text { Development } \\
\text { partnership } \\
\text { projects (SCPP) }\end{array}$} & \multirow{2}{*}{$\begin{array}{c}\text { Chapter } 4 \\
\text { Mediated } \\
\text { partnership } \\
\text { (Motramed) }\end{array}$} & \multirow{2}{*}{$\begin{array}{l}\text { Chapter } 5 \\
\text { Extension }\end{array}$} \\
\hline & $\begin{array}{l}\text { RSPO (private } \\
\text { certification) }\end{array}$ & $\begin{array}{l}\text { ISPO (public } \\
\text { certification) }\end{array}$ & & & \\
\hline Initiator & Top-down & Top-down & Top-down & Bottom-up & Top-down \\
\hline Scale & International & National & $\begin{array}{ll}\text { - } & \text { International } \\
\text { - } & \text { National } \\
\text { - } & \text { Regional/local }\end{array}$ & Regional/local & $\begin{array}{ll} & \text { National; } \\
\text { - } & \text { Regional } \\
& \text { /local }\end{array}$ \\
\hline Tensions & $\begin{array}{l}\text { - Public and } \\
\text { private re- } \\
\text { sponsibility } \\
\text { - Global and } \\
\text { local values } \\
\text { - Knowledge } \\
\text { to practice }\end{array}$ & $\begin{array}{l}\text { Knowledge } \\
\text { to practice }\end{array}$ & 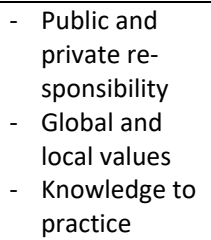 & 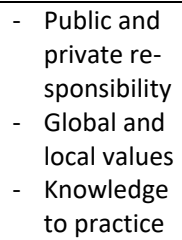 & $\begin{array}{ll}\text { - } & \text { Global and } \\
\text { local values } \\
\text { - } & \text { Knowledge } \\
\text { to practice }\end{array}$ \\
\hline
\end{tabular}

Chapter 2, 'Toward a new scenario in agricultural sustainability certification? The response of the Indonesian national government to private certification', analyzes a new development in the relationships between private sustainability standards and governments; one in which southern governments reclaim the authority from mainly northernbased businesses and NGOs. It examines how the Indonesian government, a forerunner in this field, responds to the private certification of palm oil (RSPO). The results of this indepth study are compared with similar trends in the coffee and cocoa sector in Indonesia. The chapter observes that a change takes place from a nonresponsive stance, a modest involvement in terms of sustaining the implementation of private certifications, to an active development of alternative public national standards and certifications. The chapter defines some factors that facilitate the development of Southern public standards as an addition or alternative to private regulations and reviews the implications for the future of private standards and certifications.

Chapter 3, 'Governance challenges of cocoa partnership projects in Indonesia: Seeking synergy in multi-stakeholder arrangements for sustainable agriculture, ' gives a clearer illustration of the claiming process in the decentralized and fragmented governance system in Indonesia. This chapter investigates multi-stakeholder arrangements initiated by businesses and NGOs from the North that aim to enhance a more sustainable agricultural production at specific localities in Southern countries. We aim to better understand the search for concerted action in multi-actor arrangements. Therefore, this chapter presents a diagnostic framework with three strategic challenges the partnership projects are facing: linking global economic objectives to local needs, values and interests; bridging public and private interests and responsibilities; and seeking trade-offs between social, environmental and economic values. Starting from the partnerships' Theory of Change, this diagnostic framework is applied to comparative case-studies of partnership projects in the cocoa sector in Indonesia, which are part of a Northern-based publicprivate partnership to improve farmers' prospective. It is concluded that the economic reality faced by the farmers differs from that of the Northern actors; collaboration with 
governments is difficult because of different organizational cultures; and the partnership projects underestimate the strength of vested social relations the smallholders are part of. Overall, the initiators of the partnerships seem to work with a too restricted economic interpretation of the local reality.

Chapter 4, 'The mediated partnership model for sustainable coffee production: Experiences from Indonesia', investigates how a bottom-up agricultural development project, rooted in the practices of the smallholders and their (local) networks, might relate to global sustainability standards and certification schemes. Such an initiative starts with the economic interests of the farmers and may result in sustainability certification afterwards. The chapter particularly investigates an approach to implement a more sustainable coffee production at the local level in Indonesia - the Mediated Partnership Model (Motramed). We conceptualize this model, initiated by an Indonesian research institute, as a form of collaborative governance to create a new, more sustainable management practice. We particularly focus on four critical mechanisms in the partnering process: defining a common problem, building trust, exploring collaborative advantages and the leadership role. Empirical research was conducted in three regions; Bali, Flores and Java. In the conclusion, we define several critical factors that need to be addressed to further develop similar bottom-up partnerships for more varied agricultural commodities.

The last empirical chapter, Chapter 5, 'Public agricultural extension workers as boundary workers: Identifying sustainability perspectives in agriculture using Qmethodology', examines the role of public extension workers as boundary workers in Indonesia. We conceptualize good boundary work as the ability to develop a similar perspective on sustainable agriculture by extension workers and their respective farmers. A similar perspective implies that extension workers have fulfilled their function as boundary worker in translating the abstract concept of sustainability into salient knowledge for farmers. We used Q-methodology to analyze perspectives on sustainability, which resulted in two perspectives; the technologist and the environmentalist. The technologists perceive sustainable agriculture as the use of organic pesticides, and they strongly agree that the responsibility for sustainable agriculture belongs to extension workers. The environmentalists value the environmental aspects of sustainable agriculture. The chapter describes three case studies that differ in the quality of their extension work. Good boundary work needs some prerequisites; highly motivated extension workers; the ability to gain trust from farmers; willingness of farmers to adopt new knowledge from extension workers; and government support for extension.

Regarding our first research question - government involvement - we observe a noticeable difference between the national government and local governments. At the national level, the government reclaims its authority over private standards and certifi- 
cation through the development of alternative and competing public regulations on palm oil, coffee and cocoa. A different form of claiming national authority became apparent in our research of the partnership projects where an NGO collaborates with the district government. These partnership projects are currently being developed in many districts in Indonesia. As a reaction, the national government tried to claim its authority in these types of arrangements by indirectly regulating the activities of international civil society organizations in Indonesia. Through a Memorandum of Understanding (MoU) at the national level between the NGO and the ministries, the government strengthened its grip on these arrangements. Our research at the local level reveals a different way of claiming government authority. In general, local governments seem to be more pragmatic in their reaction to external attempts to induce a more sustainable agricultural production. They are more inclined to consider what would serve their own interests, such as regional economic growth and resources for regional development, even though the progress of the projects differs from district to district. We also observed some animosity between district governments and provincial governments, as district officials tend to operate independently of provincial policies. Local governments play a more active role in the mediated partnership projects, as it is ensured that the project activities fit into their regional strategy and policies. In these cases, the local governments and other actors together set the agenda to realize collective advantages, with local governments actively involved in the implementation process. Different from partnerships at the national level, which tend to lead to complex multi-level coordination problems, local governments can work in smaller scope projects in which all involved parties can explore their respective advantages. A similar pattern became visible in our research on the performance of agricultural extension. Since the decentralization period, extension is determined by the interests of local governments. Consequently, the quality of extension services differs from region to region. With the support of local governments, extension workers are more motivated to perform their role as boundary workers than if they were not to receive any support.

Regarding our second research question, challenges and responses, we observe that various problematic issues hinder the process of developing government authority for a more sustainable agricultural production of plantation commodities such as coffee, cocoa, and palm oil. First, the overly formal and bureaucratic process in governmental offices may slow down the progress. Second (and related), we observe problematic communication and coordination processes between governmental offices in Indonesia. Third, the bureaucratic process goes together with a very personalized way of governing, in the sense that it is important to know the right people to effectively find your way in the bureaucracy. Fourth, the restricted definition of sustainability that Southern actors adhere to may pose a barrier to achieve a more sustainable agricultural system. Sustainability standards interpreted by the Northern actors mainly serve the consumers' 
interests in an environmentally friendly and socially responsible production. The Southern actors tend to consider these aspects as less important than economic profit. Fifth, the Indonesian government gives less priority to export-oriented commodities (coffee and cocoa) compared to rice which results in generally poor extension services.

Regarding our third research question, interference of the government in processes toward a more sustainable agriculture, we consider three potential futures for the Indonesian government. We defined them as Accommodating the global market; Countering the global market; and Fostering the partnership model. Regarding the last-mentioned future, we discuss some new approaches that were initiated during our dissertation research: the FAIR partnerships, the landscape approach, and the jurisdictional approach. We argue that none of these approaches seems to be able to transform traditional production methods in sustainable ones on their own. In our view, a viable theory of change would explore how the approaches can be related to each other as parts of a more elaborated approach. This approach would primarily seek connections between the strengths of the different ways forward. This, however, requires an overall national vision on the future of the production of agricultural commodities, strong strategic thinking, as well as the development of an operational implementation strategy. Such an approach cannot be developed by a single government agency, at one level, or only by public actors. It requires a national public-private multi-stakeholder platform to foster the dialogue. Regarding follow-up research, we suggest working out the relationships between the different ways forward in scenarios based on an overall vision regarding a more sustainable production of agricultural commodities. 



\section{Ringkasan}

\section{Standar keberlanjutan yang diperdebatkan di pertanian Indonesia:}

Dalam proses mengklaim kewenangan pemerintah

Dalam kurun dua puluh tahun terakhir, kita telah melihat pertumbuhan standar keberlanjutan swasta dan skema sertifikasi yang membicarakan tentang produksi komoditas pertanian di negara-negara Selatan. Sebagian besar pendekatan tersebut dikembangkan oleh perusahaan dan organisasi non-pemerintah (Ornop) yang berbasis di Utara atau melalui pengaturan kemitraan diantara keduanya. Sementara itu, sistem dan standar keberlanjutan yang sangat kompleks dan sering membingungkan telah terwujud. Dalam disertasi ini, kami berpendapat bahwa pemerintahan dari Selatan, seperti Indonesia, perlu mempertimbangkan kembali kewenangan mereka dalam sistem pasar. Proses 'claiming authority' ini menciptakan banyak ketegangan, karena direalisasikan dalam sistem pemerintahan yang terdesentralisasi dan terfragmentasi melalui berbagai pengaturan kelembagaan. Kami juga mengamati bahwa dalam beberapa tahun terakhir, pemerintah-pemerintah Selatan mengembangkan alternatif publik sebagai bentuk mengklaim kembali kewenangan publik dari standar swasta dan skema sertifikasi.

Disertasi ini membahas bagaimana posisi pemerintah Indonesia dalam kontestasi keberlanjutan dan berbagai cara Indonesia mengklaim kewenangannya dalam konfrontasi dengan standar dan sertifikasi swasta yang berbasis dari Utara. Oleh karena itu, disertasi ini bertujuan untuk menjawab tiga pertanyaan utama berikut ini:

1. Bagaimana dan mengapa pemerintah Indonesia terlibat dalam kontestasi keberlanjutan dalam produksi pertanian tanaman perkebunan?

2. Tantangan apa yang dihasilkan melalui keterlibatan tersebut bagi pemerintah dan bagaimana pemerintah menanggapi tantangan tersebut?

3. Apa implikasi keterlibatan tersebut dalam bentuk campur tangan pemerintah yang layak dalam proses menciptakan produksi pertanian yang lebih berkelanjutan?

Dalam penelitian kami, kami secara khusus fokus pada berbagai cara di mana pemerintah Indonesia mengklaim kewenangannya dalam berbagai pengaturan kelembagaan. Lihat tabel di bawah ini. 


\begin{tabular}{|c|c|c|c|c|c|}
\hline \multirow[b]{2}{*}{$\begin{array}{l}\text { Bentuk } \\
\text { pengaturan } \\
\text { kelemba- } \\
\text { gaan }\end{array}$} & \multicolumn{2}{|c|}{ Bab 2} & \multirow[b]{2}{*}{$\begin{array}{c}\text { Bab } 3 \\
\text { Proyek } \\
\text { kemitraan } \\
\text { pembangunan } \\
\text { (SCPP) }\end{array}$} & \multirow[b]{2}{*}{$\begin{array}{c}\text { Bab } 4 \\
\text { Model } \\
\text { Kemitraam } \\
\text { Bermediasi } \\
\text { (Motramed) }\end{array}$} & \multirow{2}{*}{$\begin{array}{c}\text { Bab } 5 \\
\begin{array}{c}\text { Penyuluhan } \\
\text { pertanian }\end{array}\end{array}$} \\
\hline & $\begin{array}{l}\text { RSPO (sertifikasi } \\
\text { swasta kelapa } \\
\text { sawit) }\end{array}$ & $\begin{array}{c}\text { ISPO } \\
\text { (sertifikasi } \\
\text { publik } \\
\text { kelapa } \\
\text { sawit }\end{array}$ & & & \\
\hline Pengusul & Top-down & Top-down & Top-down & Bottom-up & Top-down \\
\hline Cakupan & Internasional & Nasional & $\begin{array}{ll}\text { - } & \text { Internasional } \\
\text { - } & \text { Nasional } \\
\text { - } & \text { Regional/lokal }\end{array}$ & Regional/lokal & $\begin{array}{ll}\text { - } & \text { Nasional; } \\
\text { - } & \text { Regional } \\
& \text { /lokal }\end{array}$ \\
\hline Ketegangan & $\begin{array}{l}\text { - Tanggung } \\
\text { jawab publik } \\
\text { dan swasta } \\
\text { - Nilai-nilai } \\
\text { global dan } \\
\text { lokal } \\
\text { - Pengetahuan } \\
\text { dan praktik }\end{array}$ & $\begin{array}{l}\text { Pengetahu- } \\
\text { an dan } \\
\text { praktik }\end{array}$ & $\begin{array}{l}\text { - } \text { Tanggung } \\
\text { jawab publik } \\
\text { dan swasta } \\
\text { - } \\
\text { Nilai-nilai } \\
\text { global dan } \\
\text { lokal } \\
\text { - } \\
\text { Pengetahuan } \\
\text { dan praktik }\end{array}$ & 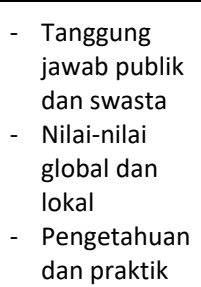 & $\begin{array}{ll}\text { - } & \text { Nilai-nilai } \\
& \text { global dan } \\
& \text { lokal } \\
\text { - } & \text { Pengetahuan } \\
& \text { dan praktik }\end{array}$ \\
\hline
\end{tabular}

Bab 2, 'Menuju skenario baru dalam sertifikasi keberlanjutan pertanian? Tanggapan pemerintah nasional Indonesia terhadap sertifikasi swasta ', menganalisis perkembangan baru dalam hubungan antara standar keberlanjutan swasta dan pemerintah; di mana pemerintah selatan mengklaim kembali kewenangan dari sebagian besar actor bisnis dan Ornop berbasis utara. Bab ini mengkaji bagaimana pemerintah Indonesia, pelopor dalam bidang ini, menanggapi sertifikasi kelapa sawit swasta (RSPO). Hasil studi mendalam ini dibandingkan dengan tren serupa di sektor kopi dan kakao di Indonesia. Bab ini mengamati bahwa perubahan terjadi mulai dari sikap yang tidak responsif, keterlibatan yang sederhana dalam hal pelaksanaan sertifikasi swasta, hingga pengembangan alternatif standar dan sertifikasi nasional. Bab ini mengidentifikasi beberapa faktor yang memfasilitasi pengembangan standar publik dari negara Selatan sebagai tambahan atau alternatif terhadap peraturan swasta dan meninjau implikasinya untuk masa depan standar dan sertifikasi swasta.

Bab 3, 'Tantangan tata kelola proyek kemitraan kakao di Indonesia: Mencari sinergi dalam pengaturan multipihak untuk pertanian berkelanjutan,' memberikan ilustrasi yang lebih jelas mengenai proses klaim dalam sistem tata pemerintahan yang terdesentralisasi dan terfragmentasi di Indonesia. Bab ini menyelidiki pengaturan multipihak yang diprakarsai oleh perusahaan dan Ornop dari Utara yang bertujuan untuk meningkatkan produksi pertanian yang lebih berkelanjutan di daerah tertentu di negaranegara Selatan. Kami bertujuan untuk lebih memahami pencarian tindakan bersama dalam pengaturan multi-aktor. Oleh karena itu, bab ini menyajikan kerangka diagnostik dengan tiga tantangan strategis yang dihadapi proyek kemitraan: menghubungkan tujuan ekonomi global dengan kebutuhan, nilai, dan kepentingan lokal; menjembatani kepentingan dan tanggung jawab publik dan swasta; dan mencari keseimbangan antara 
nilai sosial, lingkungan dan ekonomi. Berawal dari Teori Perubahan dari kemitraan, kerangka diagnostik ini diterapkan pada studi kasus komparatif mengenai proyek kemitraan di sektor kakao di Indonesia, yang merupakan bagian dari kemitraan publikswasta berbasis Utara untuk meningkatkan prospektif petani. Disimpulkan bahwa kenyataan ekonomi yang dihadapi petani berbeda dengan yang dibayangkan oleh aktor dari Utara; kerja sama dengan pemerintah sulit karena budaya organisasi yang berbeda; dan proyek kemitraan meremehkan kekuatan relasi sosial dimana para petani kecil berada. Secara keseluruhan, penggagas kemitraan tampaknya bekerja dengan pemaknaan ekonomi yang terbatas terhadap realitas lokal.

Bab 4, 'Model kemitraan yang dimediasi untuk produksi kopi berkelanjutan: Pengalaman dari Indonesia', menyelidiki bagaimana sebuah proyek pengembangan pertanian bottom-up (pendekatan dari bawah ke atas), yang berakar pada praktik petani kecil dan jaringan lokal mereka, mungkin terkait dengan standar keberlanjutan global dan skema sertifikasi. Inisiatif semacam itu dimulai dengan kepentingan ekonomi petani dan selanjutnya dapat menghasilkan sertifikasi keberlanjutan. Bab ini secara khusus menyelidiki sebuah model untuk merealisasikan produksi kopi yang lebih berkelanjutan di tingkat lokal di Indonesia - Model Kemitraan Bermediasi (Motramed). Kami mengkonseptualisasikan model ini, diprakarsai oleh lembaga penelitian Indonesia, sebagai bentuk tata kelola kolaboratif untuk menciptakan praktik manajemen baru yang lebih berkelanjutan. Kami secara khusus berfokus pada empat mekanisme penting dalam proses kemitraan: mendefinisikan masalah umum, membangun kepercayaan, mengeksplorasi keuntungan kolaboratif dan peran kepemimpinan. Penelitian empiris dilakukan di tiga wilayah; Bali, Flores dan Jawa. Pada kesimpulan, kami mendefinisikan beberapa faktor penting yang perlu ditangani untuk mengembangkan kemitraan bottom-up serupa untuk komoditas pertanian yang lebih bervariasi.

Bab empiris terakhir, Bab 5, 'Penyuluh pertanian masyarakat sebagai pekerja batas: Mengidentifikasi perspektif keberlanjutan di bidang pertanian dengan menggunakan Qmetodologi', memeriksa peran penyuluh publik sebagai pekerja batas di Indonesia. Kami mengkonseptualisasikan kerja batas yang baik dengan kemampuan untuk mengembangkan perspektif yang sama mengenai pertanian berkelanjutan oleh para penyuluh dan petani binaannya masing-masing. Perspektif yang sama menyiratkan bahwa penyuluh telah memenuhi fungsinya sebagai pekerja batas dalam menerjemahkan konsep abstrak tentang keberlanjutan menjadi pengetahuan yang penting bagi petani. Kami menggunakan Q-metodologi untuk menganalisis perspektif tentang keberlanjutan, yang menghasilkan dua perspektif; Teknologi dan Lingkungan. Perspektif teknologi mengasosiasikan pertanian berkelanjutan dengan penggunaan pestisida organik, dan mereka sangat setuju bahwa penyuluh bertanggung jawab untuk mewujudkan pertanian berkelanjutan. Perspektif lingkungan menghargai aspek lingkungan dalam pertanian berkelanjutan. Bab ini menjelaskan tiga studi kasus yang 
berbeda dalam kualitas pekerjaan penyuluhan mereka. Pekerjaan batas yang baik membutuhkan beberapa prasyarat; penyuluh yang bermotivasi tinggi; kemampuan untuk mendapatkan kepercayaan dari petani; kesediaan petani untuk mengadopsi pengetahuan baru dari penyuluh; dan dukungan pemerintah untuk bidang penyuluhan.

Mengenai pertanyaan penelitian pertama dalam disertasi ini - keterlibatan pemerintah - kami mengamati perbedaan yang nyata antara pemerintah nasional dan pemerintah daerah. Pada tingkat nasional, pemerintah mengklaim kembali kewenangannya atas standar dan sertifikasi swasta melalui pengembangan peraturan publik alternatif yang bersaing pada kelapa sawit, kopi dan kakao. Bentuk lain dari klaim kewenangan nasional menjadi jelas dalam penelitian kami tentang proyek kemitraan dimana sebuah Ornop bekerja sama dengan pemerintah kabupaten. Proyek kemitraan ini saat ini sedang dikembangkan di banyak kabupaten di Indonesia. Sebagai reaksi, pemerintah nasional mencoba untuk mengklaim kewenangannya dalam pengaturan semacam ini dengan secara tidak langsung mengatur kegiatan organisasi nonpemerintah asing di Indonesia. Melalui Nota Kesepahaman (Memorandum of Understanding / MoU) di tingkat nasional antara Ornop dan kantor kementrian, pemerintah memperkuat cengkeramannya dakam skema pengaturan ini. Penelitian kami di tingkat lokal menunjukkan cara yang berbeda untuk mengklaim otoritas pemerintah. Secara umum, pemerintah daerah tampaknya lebih pragmatis dalam reaksi mereka terhadap upaya eksternal untuk menginduksi produksi pertanian yang lebih berkelanjutan. Pemerintah daerah lebih cenderung mempertimbangkan apa yang dapat memenuhi kepentingan mereka, seperti pertumbuhan ekonomi daerah dan sumber daya untuk pembangunan daerah, walaupun kemajuan proyek berbeda dari kabupaten ke kabupaten. Kami juga mengamati adanya pertentangan antara pemerintah kabupaten dan pemerintah provinsi, karena pejabat kabupaten cenderung bertindak secara independen dari kebijakan provinsi. Pemerintah daerah memainkan peran yang lebih aktif dalam proyek kemitraan yang dimediasi, karena memastikan bahwa kegiatan proyek sesuai dengan strategi dan kebijakan regional mereka. Dalam kasus ini, pemerintah daerah dan aktor lainnya bersama-sama menyusun agenda untuk mewujudkan keuntungan kolektif, dengan pemerintah daerah terlibat aktif dalam proses pelaksanaan. Berbeda dengan kemitraan di tingkat nasional, yang cenderung menimbulkan masalah koordinasi multi-level yang kompleks, pemerintah daerah dapat bekerja dalam lingkup proyek yang lebih kecil di mana semua pihak yang terlibat dapat mengeksplorasi keuntungan prospektif. Pola serupa terlihat dalam penelitian kami tentang kinerja penyuluhan pertanian. Sejak masa desentralisasi, penyuluhan pertanian ditentukan oleh kepentingan pemerintah daerah. Akibatnya, kualitas layanan penyuluhan berbeda dari satu daerah ke daerah lainnya. Dengan dukungan pemerintah daerah, penyuluh lebih termotivasi untuk menjalankan peran mereka sebagai pekerja batas daripada jika mereka tidak menerima dukungan apapun. 
Mengenai pertanyaan penelitian kedua, tantangan dan tanggapan pemerintah, kami mengamati bahwa berbagai masalah menghambat proses pengembangan wewenang pemerintah untuk produksi pertanian perkebunan seperti kopo, kakao dan kelapa sawith yang lebih berkelanjutan dari komoditas perkebunan. Pertama, proses birokrasi yang terlalu formal dan birokratis di kantor pemerintahan yang dapat memperlambat kemajuan. Kedua (dan terkait), kami mengamati proses komunikasi dan koordinasi yang bermasalah antara kantor-kantor pemerintahan di Indonesia. Ketiga, proses birokrasi berjalan bersamaan dengan tata pemerintahan yang sangat personal, dalam artian penting untuk mengetahui orang-orang yang tepat untuk secara efektif menemukan jalan di birokrasi. Keempat, definisi keberlanjutan yang terbatas yang dapat dimainkan oleh aktor-aktor Selatan dapat menjadi penghalang untuk mencapai sistem pertanian yang lebih berkelanjutan. Standar keberlanjutan yang ditafsirkan oleh aktor Utara terutama yang melayani kepentingan konsumen dalam produksi yang ramah lingkungan dan bertanggung jawab secara sosial. Aktor Selatan cenderung menganggap aspek ini kurang penting daripada keuntungan ekonomi. Kelima, pemerintah Indonesia kurang mengutamakan komoditi berorientasi ekspor (kopi dan kakao) dibandingkan beras yang berakibat pada penyuluhan yang berkualitas rendah pada umumnya.

Mengenai pertanyaan penelitian ketiga, campur tangan pemerintah dalam proses menuju pertanian yang lebih berkelanjutan, kami mempertimbangkan tiga potensi masa depan bagi pemerintah Indonesia. Kami mendefinisikannya sebagai Mengakomodasi pasar global; Melawan pasar global; dan Membina model kemitraan. Mengenai masa depan yang disebutkan terakhir, kami membahas beberapa pendekatan baru yang dikembangkan selama penelitian disertasi kami: kemitraan FAIR, pendekatan lansekap, dan pendekatan yurisdiksi. Kami berpendapat bahwa tidak satu pun dari pendekatan ini dapat mengubah metode produksi tradisional secara berkelanjutan dengan sendirinya. Menurut pandangan kami, teori perubahan layak akan mengeksplorasi bagaimana pendekatan tersebut dapat dikaitkan satu sama lain sebagai bagian dari pendekatan yang lebih terperinci. Pendekatan ini terutama mencari hubungan antara kekuatan dari berbagai cara ke depan. Namun, ini memerlukan visi nasional secara keseluruhan mengenai masa depan produksi komoditas pertanian, pemikiran strategis yang kuat, serta pengembangan strategi operasional. Pendekatan semacam itu tidak dapat dikembangkan oleh satu lembaga pemerintah, pada satu tingkat, atau hanya oleh aktor publik. Ini membutuhkan platform multi-pihak publik-swasta nasional untuk mendorong dialog. Mengenai penelitian lanjutan, kami menyarankan untuk focus pada hubungan antara berbagai cara ke depan dalam skenario berdasarkan visi keseluruhan mengenai produksi komoditas pertanian yang lebih berkelanjutan. 



\section{Valorization}

This dissertation discusses the different ways the Indonesian government claims its authority in contestations regarding sustainability standards in the agricultural production sector. People outside the agricultural sector are often not aware of these contestations. Even actors who are closely related to the agricultural sector, such as farmers and local governments are (as we have seen in some cases in the empirical chapters) often not fully aware of the content and implications of sustainability standards and certification schemes. This dissertation intends not only to contribute to scientific knowledge, but also to a more sustainable practice. This valorization will describe how our findings could be of value, and how they could be made accessible for the actors involved in a more sustainable production of agricultural communities. In addition to that, my background as a lecturer who adheres to the three principles of Higher Education or "Tri Dharma Perguruan Tinggi" (education and teaching, research, and community service), will be incorporated in this valorization.

\section{Relevance}

This dissertation offers insights into governance practices aimed at creating a more sustainable agriculture in producing countries. The research is motivated by the trend of private sustainability standards and certification schemes that mainly work 'top-down' from Northern actor's demands and prerequisites to the farming practices of producers. The position of producers and their working conditions at the farm level seem to be frequently neglected in the development of these standards.

We understand that this kind of institutional arrangement is part of a neoliberal trend in which the government reduces its intervention in the market system. Nevertheless, we argue that southern governments have an influential position regarding the implementation of the private sustainability standards at the producer level. However, these governments are not yet fully aware that through their public authority (i.e., law and regulations), they might support or hinder the implementation of private sustainability standards in the producing countries. Therefore, this dissertation focuses on the process of claiming authority of the Indonesian government in different institutional arrangements on sustainability. This dissertation aims to raise awareness of these institutional arrangements and offers information that could be used by public and private actors to create better-formulated policies that fit the interests at the producer level.

Chapter 2 provides information regarding the new development of southern public sustainability standards as a way the Indonesian government reclaims its authority over private sustainability standards and certification schemes. Chapter 3 gives information about the process of claiming authority in the decentralized and fragmented governance 
system in Indonesia through the involvement of the government in multi-stakeholder arrangements. Chapter 4 provides information about a different way of claiming authority through the bottom-up mediated partnership model, which may be more successful in the fragmented governance system than top-down arrangements would be. In this chapter, we determine critical factors that need to be addressed in order to further develop such bottom-up partnerships in other regions and with regards to other commodities. The last empirical chapter, chapter 5, provides information regarding the perspectives on sustainable agriculture among extension workers and their farmers.

Not only is this dissertation scientifically relevant, but it is also socially relevant, as it provides information to improve governance in the agricultural sector. Although the focus of this dissertation is on the Indonesian government, it also provides valuable findings for other actors, such as businesses, NGOs, development organizations and farmers' organizations that are also concerned with improving farmer welfare and more sustainable agricultural production.

\section{Target groups and activities}

Awareness of more sustainable agricultural production has become increasingly important in the last two decades due to the emergence of private sustainability standards and certification schemes. Many actors who worked in the agricultural sector are now more aware of the demand for more sustainable products. This dissertation is relevant for the academic community and specific groups related to the agricultural sector. In the following, we list the groups that may be interested in the results of this research and how we aim to communicate our findings to them.

\section{Government officials}

The main actors studied in this dissertation are Indonesian governments, within a broader focus on fragmented and layered levels of government (national, provincial, and district level). It started with the issue of private certification on palm oil in chapter 2 , which has become a hot topic in the last decade and has affected Indonesia's trade. The new development of a public standard for palm oil (ISPO) is a major step for Indonesia and the palm oil sector in general. It indicated that the national government has become more aware and is starting to play an active role in the discussion on sustainability claims. Involvement of the government has become inevitable as it has the authority to regulate the agricultural sector by issuing laws and regulations. Legality is something that private actors cannot deliver. For southern governments, the dissertation shows the different ways of claiming authority and their implications for attempts to create a more sustainable agriculture. 
The cases in the dissertation may help national and local governments be better informed when determining their role in various institutional arrangements and when formulating viable policies that accommodate farmers' interests. The results may help the government to better formulate public policy in the agricultural sector. To communicate the findings, we will arrange meetings with governmental agencies and urge them to reflect upon ways they could stimulate agricultural sustainability while increasing farmers' income at the same time. First, we will establish communication with the district government of Semarang and the provincial government of Central Java, where my university is located, to inform them about the findings of this dissertation. Besides, we could apply for government grants to conduct further research with regards to the various types of government involvement in sustainable institutional arrangements and the ways to improve the agricultural sector in Central Java in general.

Another issue that my research shows to be of importance is the agricultural extension system (Chapter 5), which aims to improve farmer welfare and their knowledge about sustainable agriculture. However, the quality of this extension varies between the different regions in Indonesia. The results in chapter 5 offer insights that can help the national government to better formulate a comprehensive extension policy that applies to all regions.

\section{Science community and research center}

This dissertation is sure to be of interest and value for research centers and the science community as a whole. Its contribution to the governance literature and the empirical insights regarding the claiming process provide a basis for further discussion and research. In chapter 4, we saw that a research center on coffee and cocoa (the Indonesian Coffee and Cocoa Research Institute, ICCRI) developed a model to increase farmers' coffee production capacity. Together with ICCRI, we at the Center for Study and Development of Rural Communities at the Semarang State University Faculty of Social Science will help to scale up and stimulate wider adoption of this model for other agricultural commodities in more regions in Indonesia. We suggest applying for a multi-year grant from the Indonesian government to conduct this action research.

\section{Private actors (business and NGOs)}

For business actors, this dissertation provides information on the capabilities of partners and on strategies for developing partnerships with public actors and farmers. As we have seen in chapter 3 and 4 , the results identify critical factors that need to be addressed in order to develop public-private partnerships for more sustainable agricultural production. Each actor could achieve its objectives by better exploring the collaborative advantages a partnership has to offer. This study might be of interest to business actors in better developing their policy or business strategy and it offers information on how to 
deal with farmers. This dissertation is also relevant for NGOs, as it provides information about potential strategies and challenges faced by actors in such partnerships. We could disseminate the findings in the dissertation through the organization of a seminar or workshop, and inviting business actors and NGOs that are involved in the sustainability standards on agricultural plantation commodities.

\section{Farmers' organizations}

For farmer groups in general, this dissertation may yield lessons that were derived from the experiences of other farmers that participated in the many training and development projects arranged by the government or private actors. The research in this dissertation mainly took place in regions outside Java island, such as Sulawesi, Bali and Flores, as many NGOs and development organizations have opted to specifically assist farmers in those regions to improve their capacity. However, these NGOs are hardly present on Java, as little attention is paid to cash crop farmers there. This dissertation could encourage cash crop farmers in Java to adopt the experiences of their fellow farmers outside Java. For example, with the support of the local governments, coffee farmers in Central Java could be motivated to follow in the steps of farmers in Bajawa and Bali through Motramed. Communicating the findings in this dissertation to farmers' organizations will be done through community service in the form of a workshop with the representatives of the farmers' organizations, with the aims to raise awareness on sustainability standards and to introduce certification schemes among Javanese farmers. Further research will be embedded in the Center for Study and Development of Rural Communities at the Department of Sociology and Anthropology of Semarang State University, and aim to identify the potential and social and economic aspects of institutional arrangements in some regions in Java (such as Motramed). This research can be done in cooperation with the local governments as part of the government's agenda in improving agricultural sector.

\section{Teaching}

The last empirical chapter examines the role of public extension workers as boundary workers in Indonesia using Q-methodology. We are interested in using Q-methodology because it is rarely used among scholars in Indonesia or in relation to agriculture in general. This chapter contributes specifically to the principle of teaching and education in the higher education system. Q-methodology could be a good alternative the qualitative approach that students often use for their final theses at the Department of Sociology and Anthropology. In this regard, students will receive step-by-step training in the use of Q-methodology during a methodology workshop, and it is also possible to include Qmethodology training in the Research Methodology course. The use of Q-methodology in further research on the agricultural and rural community at the Center for Study and 
Development of Rural Communities in the department will also be encouraged. Furthermore, Q-methodology could be used to enrich research on gender and environmental conservation as well. As such, the Q-methodology training will not be restricted to students from the Sociology and Anthropology department, and could be shared with students from the Department of Politics, Psychology and Public Health at Semarang State University.

\section{Schedule and implementation}

The dissemination of the findings of this dissertation to target groups will be incorporated into the teaching, research, and community service performed by the researcher, soon after her return to the University. Furthermore, some dissemination of the findings has already taken place. Two articles based on the first and second empirical studies have been published in international journals and cited by other scholars, and research results have been presented at international conferences in Singapore and Indonesia in 2016. To widen the impact of the research, in the short term, we will present the results in a newsletter, policy briefs and articles in various media and magazines, including a local newspaper and Media Perkebunan. Other activities, such as multi-stakeholder workshops and community services, can be done as part of the program of the Center for Study and Development of Rural Communities at the Department of Sociology and Anthropology of Semarang State University. For that, an annual grant from the University and the Indonesian Ministry of Research and Technology is available. 



\section{Acknowledgements}

Writing a dissertation was not my priority at the time that I was as a junior lecturer and newlywed. However, the many encouragements to continue my study abroad I could not ignore. My most challenging journey began in 2013 and was completed in 2017 in Maastricht, the Netherlands. Meeting with so many inspiring people during my PhD time helped me to finish this dissertation. Therefore, I would like to thank all the people who played an important role and made all these things possible.

First, I would like to express my deepest gratitude to Prof. Pieter Glasbergen who kept his trust in me so that I could finish this dissertation in four years. The first two years were the hardest time for me as I had to adjust my Javanese character to accept your straightforwardness and critics. Later, I admired your commitment and dedication to your work. I have never seen a supervisor like you who intensively supervises and reads thoroughly students' work. Thank you for your guidance, valuable inputs, and enthusiasm. I would also like to send my gratitude to my co-supervisors Prof. Purwo Santoso and Prof. Pieter Leroy. Although we met each other occasionally, you always enlightened me and we had lively discussions when we met. I have learned a lot from you. Special thanks to the wonder woman, Dr. Astrid Offermans, for always having your door open to answer my questions and your quick replies to my emails. I really appreciate your detailed comments and warm words. I am glad that you were part of this project.

As this PhD was under the umbrella of SPIN (Scientific Programme Indonesia Netherlands) project 'Social and Economic effects of partnering for sustainable change in agricultural commodity chains in Indonesia' I would like to thank the Ministry of Research, Technology and Higher Education (Kemenristek-DIKTI) of the Republic Indonesia and the Royal Netherlands Academy of Arts and Sciences (KNAW) for the financial support. This project was possible because of the bilateral cooperation between ICIS - Maastricht University and Lampung University. I would like to thank all the important people who were involved in this project. Prof. Bustanul Arifin, our Indonesian leader, thank you for your valuable inputs and guidance. Thanks also for connecting me with your contacts to help me with the fieldworks. Dr. Ari Darmastuti, my advisor, thank you for accompanying me in Mamuju, West Sulawesi during my fieldwork. Thanks also for your valuable inputs, guidance, and words of encouragement. It was a pleasure to spend time with you to share my problems and concerns related to my research. Very special thanks to Dr. Surip Mawardi for your big help during my fieldwork in Bali and Bajawa on Motramed research and your inputs to the draft of the Motramed article. I have learned a lot from your dedication to coffee farmers, your humbleness, and your value of life. Special thanks to Anja van Bogaert and Ron Cörvers for your sup- 
port. To the PhD SPINers, Mbak Esa, Nia, and Mas Ibnu, thank you for the knowledge exchange, cooperation, and friendship in the last four years. Hopefully, this is not the end and we can meet each other at different events.

I want to thank all colleagues at ICIS. Thank you very much, Annet Grol, our best secretary for accommodating every time I needed help. My roommates in the last few months: Bingtao, Laura, and Nia. It was a great time we spend together in the girls' room. Thanks for the laugh, spirit, discussion, and even food. Thank you Julia, Ceren, Jing, Alex, Bram, Lukas, and all ICIS PhDs for a nice working environment and international dinner. I want to thank also Saskia, Annemarie, Veronique, Marc, Verena, Christian, Joop, Maud and all other ICIS colleagues that I cannot mention one by one.

This dissertation would not have completed without the help of informants and respondents who have spent their time to share information with the researcher during the fieldwork in Indonesia. I want to thank the informants for RSPO-ISPO research in Jakarta: the officials and staff of the Directorate of Estate Crops at the Ministry of Agriculture (Bu Frida, Bu Irmia and Pak Pras), NGO (Mas Aryo - BWI, Pak Mangga FP2SB), IDH (Mas Joko), ISPO Council (Pak Suhar), and Askindo (Pak Zulhefi). Thanks also for the Informants for cocoa partnerships research in Mamuju, Parimo, and North Luwu: ICCRI's researher (Pak Soetanto), the staff of district governmental agencies (Pak Busman, Pak Ridho, Pak Abas, Pak Herman, Pak Idrus, Pak Irman, Pak Muchtar, and Pak Andi), staff of the SC NGO (Pak Man, Pak Suharman, Pak Passen, Pak Agus, and Pak Baso), CV Marewa (Pak Idhin), farmer group (Pak Mang Ngoy), BT Cocoa Mamuju (Pak Dwi), IDH (Pak Imam), and CSP (Bu Rini). I want to thank also the Informants for Motramed research in Bali, Bajawa, and Bondowoso: the staff of the Estate Crops Agency (Pak Dewa, Bu Oka, Pak Latif, Pak Igil and Pak Ignas), coffee farmer representatives (Pak Made, Pak Wayan, Pak Jaman, Pak Jati, Om Frans, Om Leo, and Bu Lina, Pak Marhum, Pak Mat, Pak Karjo, and Pak Nanang), NGOs (Pak Adam - VECO and Rikardus - LAPMAS), exporter (Pak Asnawi and Pak Soeharman - Indokom), ICCRI's researcher (Mas Djoko), and staff of BI Jember (Pak Yuli). Moroever, thanks to the informants for extension research in North Luwu, Bondowoso, and Pelalawan: the officials of Extension Agency and Agricultural Human Resources Development of the Ministry of Agriculture (Bu Ranny, Bu Rusmini and Pak Mul), extension workers (Pak Basrul, Bu Niar, Pak Wakino, Bu Irianti, Pak Bunasin, Mba Evita, Bu Yuli, and Pak Indra), and all kind people that I met during my fieldwork in many regions in Indonesia.

Living abroad to study without family is hard, but the presence of Indonesian families and friends helped me to feel Maastricht as a second home. Many thanks to Tante Ine and Om Iwan who always opened their door for me and spoiled me with delicious Indonesian food. Thanks to the members of Pengajian Keluarga Muslim Maastricht: Teh Upi and fam, Uni Upi and fam, Mas Ferdi and Mba Nia, Tante Riyani, Mbak Eli, Kang Aep 
and fam, Kang Dani and Teh Arin, Mas Ariyanto and fam, Mas Arip and Mba Mei, Mba Novita, Mba Farida, Louise, and all Indonesian friends that I cannot mention one by one.

My journey as a PhD student could not have been started without the permission and support from my superiors at Semarang State University. My gratitude goes to the Rector, the Dean of the Social Science Faculty, and the Head of the Sociology and Anthropology Department. Many thanks to all my colleagues and family of the Sociology and Anthropology Department for their support and readiness to give me some work when I am back. Ayo giliran siapa selanjutnya untuk rehat dari rutinitas kampus?! Semangat teman-teman!

Teruntuk keluargaku, Papa dan Mama, terima kasih untuk kasih sayang dan doadoanya. Maaf, anakmu ini tidak sering-sering telpon untuk bertukar kabar. Untuk kakakkakakku, terima kasih atas dukungannya. Untuk Fina yang selalu setia menunggu Ate-nya pulang. Untuk Bapak dan Ibu, maaf dan terima kasih atas pengertiannya terhadap menantunya ini. Untuk adik-adikku, makasih dukungannya. Last but not least, my biggest supporter and life companion, my husband, Adib Amrillah, thank you for supporting me to continue my study, for listening to my stories, and for your never ending patience. Now, I that have finished my study let us start another chapter of our life. 


\section{About the author}

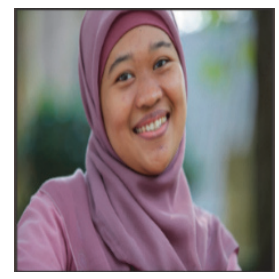

Atika Wijaya was born on the $23^{\text {rd }}$ of May 1984 in Surakarta, Indonesia. In 2001, she started her bachelor study in Public Administration at Brawijaya University and graduated in 2005. She continued her Master study in Sociology at Gadjah Mada University, with a specialization in Development Studies and graduated in 2007.

In June 2009, she started her professional career as a junior lecturer in the Sociology and Anthropology Department at Semarang State University until now. She taught a few courses: sociology of rural and urban society and sociology of development. She participated in research projects with internal grants. Some of the research topics were about community empowerment and community perceptions of environmental conservation. She is also a co-author of articles that resulted from the research. She is the main author of two articles in 2009 entitled "Pembangunan pertanian sebagai upaya meningkatkan perekonomian di pedesaan (Agricultural development as an effort to improve rural economics)" in the Journal of Social Science Forum and "Respon masyarakat terhadap perkembangan pariwisata Selo di Desa Samiran Kecamatan Selo Kabupaten Boyolali (The societal response to Selo tourism development in Samiran village Selo sub-district Boyolali district)" in the Journal of Community. Both are internal journals. Besides research, she also participated in community service in 2010 and 2011, as part of the three pillars of activity of the university. Community services regarded developing societal participation in community-based waste management, improving teachers' competency in character-based education, and developing an integrated social science laboratory in high schools.

In May 2013, she started as a PhD researcher at the International Centre for Integrated assessment and Sustainable development (ICIS) at Maastricht University under the umbrella of SPIN (Scientific Programme Indonesia - Netherlands). She participated in the project on 'Social and economic effects of partnering for sustainable change in agricultural commodity chains in Indonesia'; which is a bilateral cooperation between Maastricht University and Lampung University, with the financial support from the Ministry of Research, Technology and Higher Education (Kemenristek-DIKTI) of the Republic Indonesia and the Royal Netherlands Academy of Arts and Sciences (KNAW). In this project, she focuses on the role of Indonesian governments related to private sustainability standards and certifications schemes on agricultural commodities. During her time at ICIS, she had a lot of opportunities to participate in courses and joint SPIN workshops. She could present her work at international conferences in 2016 and published two articles in international journals. Her research interests include sustainable agriculture, governance systems, and governmental policies. 


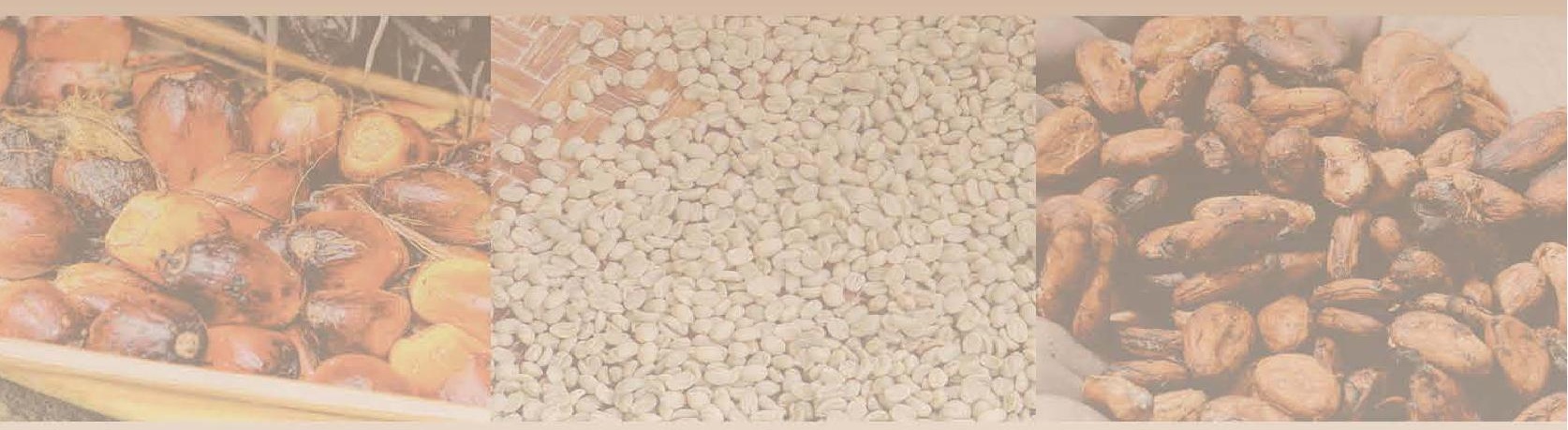

